Report of Investigation 2021-1C Kotlik

\title{
COASTAL FLOOD IMPACT ASSESSMENTS FOR ALASKA COMMUNITIES-KOTLIK
}

Richard M. Buzard, Jacquelyn R. Overbeck, Marvin M. Turner, and Jessica E. Christian

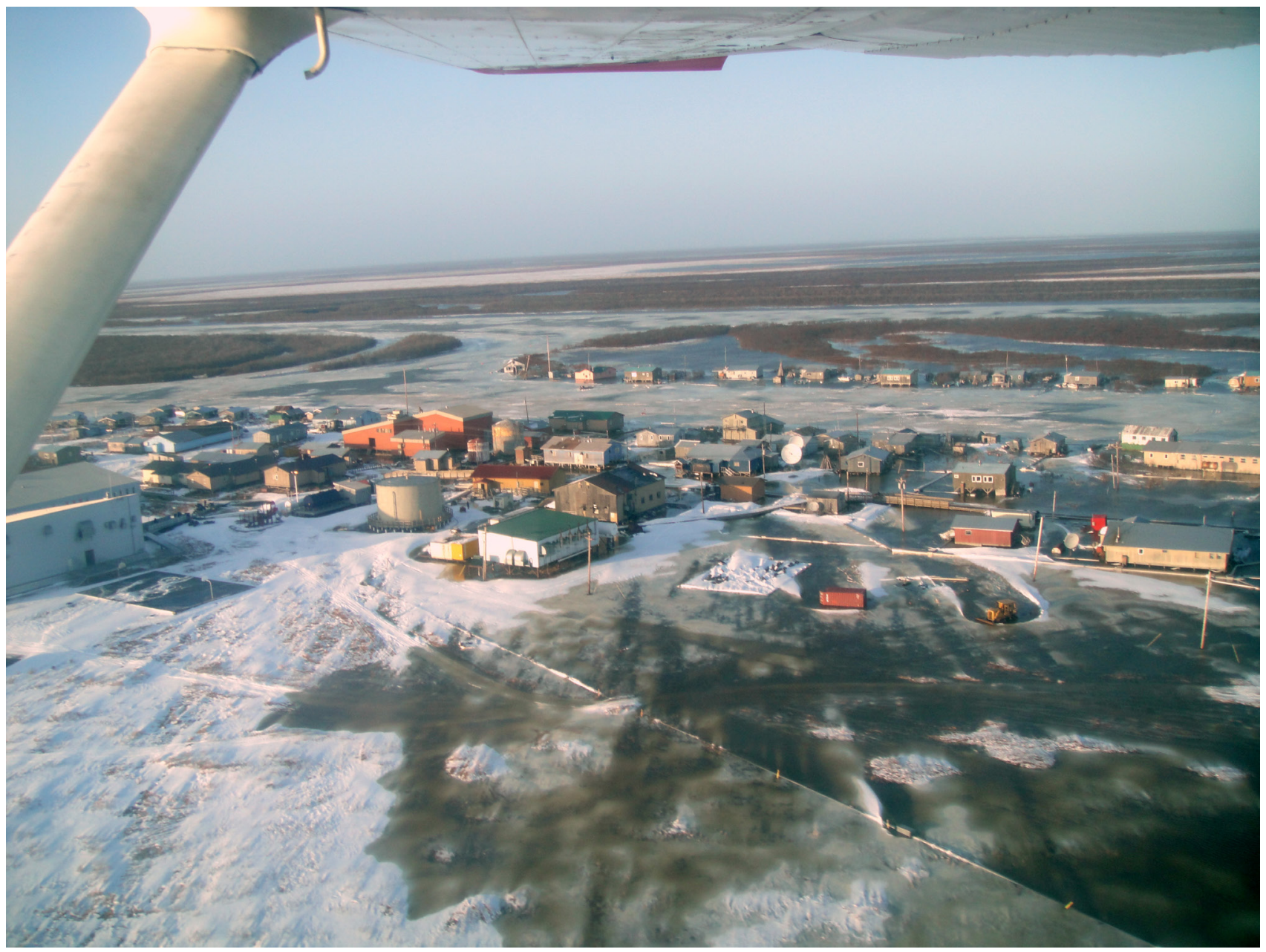

Photo from plane looking at flooding in Kotlik during the November 2011 storm. Photo: Alaska Division of Homeland Security \& Emergency Management.

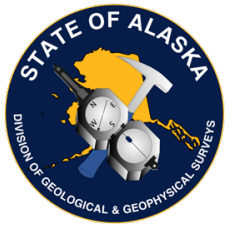

Published by STATE OF ALASKA

DEPARTMENT OF NATURAL RESOURCES DIVISION OF GEOLOGICAL \& GEOPHYSICAL SURVEYS 



\section{COASTAL FLOOD IMPACT ASSESSMENTS FOR ALASKA COMMUNITIES-KOTLIK}

Richard M. Buzard, Jacquelyn R. Overbeck, Marvin M. Turner, and Jessica E. Christian

Report of Investigation 2021-1C Kotlik

State of Alaska

Department of Natural Resources

Division of Geological \& Geophysical Surveys 


\section{STATE OF ALASKA}

Mike Dunleavy, Governor

\section{DEPARTMENT OF NATURAL RESOURCES}

Corri A. Feige, Commissioner

\section{DIVISION OF GEOLOGICAL \& GEOPHYSICAL SURVEYS}

Steve Masterman, State Geologist and Director

Publications produced by the Division of Geological \&

Geophysical Surveys (DGGS) are available for free download

from the DGGS website (dggs.alaska.gov). Publications on

hard-copy or digital media can be examined or purchased in

the Fairbanks office:

Alaska Division of Geological \& Geophysical Surveys

3354 College Rd., Fairbanks, Alaska 99709-3707

Phone: (907) 451-5010 Fax (907) 451-5050

dggspubs@alaska.gov|dggs.alaska.gov

\section{DGGS publications are also available at:}

Alaska State Library,

Historical Collections \& Talking Book Center

395 Whittier Street

Juneau, Alaska 99811

Alaska Resource Library and Information Services (ARLIS)

3150 C Street, Suite 100

Anchorage, Alaska 99503

\section{Suggested citation:}

Buzard, R.M., Overbeck, J.R., Turner, M.M., and Christian, J.E., 2022, Coastal flood impact assessments for Alaska communities: Kotlik, in Buzard, R.M., Overbeck, J.R., Chriest, Jonathan, Endres, K.L., and Plumb, E.W., Coastal flood impact assessments for Alaska communities: Alaska Division of Geological \& Geophysical Surveys Report of Investigation 2021-1C, 57 p.

https://doi.org/10.14509/30783
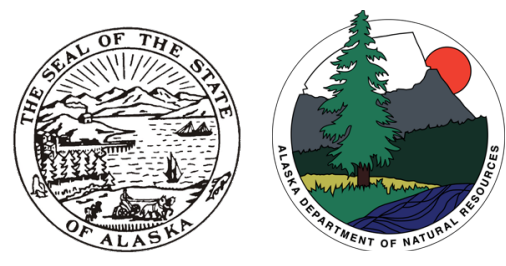



\section{Contents}

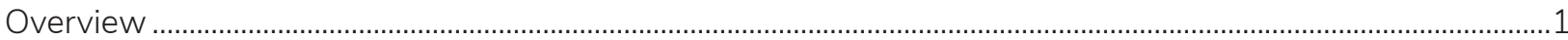

Summary

Data

Digital Elevation Models and Orthoimagery .....................................................................................................

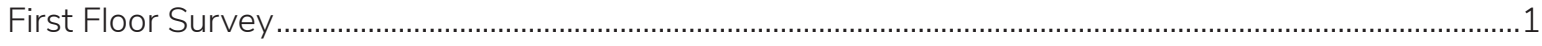

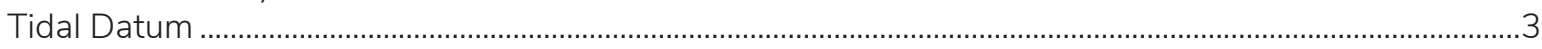

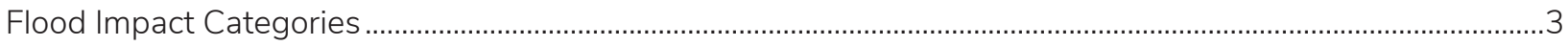

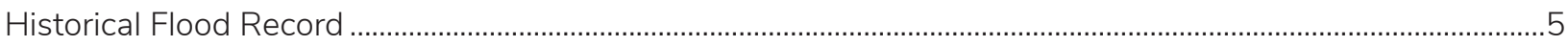

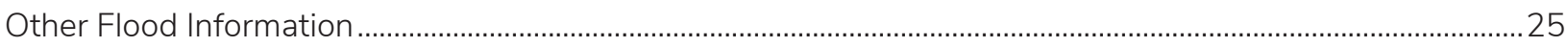

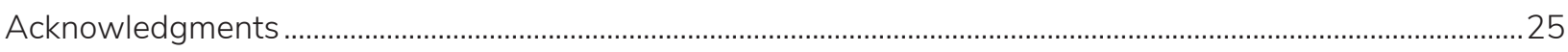

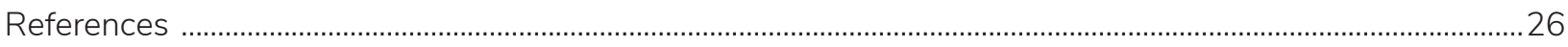

\section{Figures}

Figure 1. GNSS floor measurements of the old clinic and a residence from the 1970 s .....................................6

Figure 2. GNSS measurement of ground at residence from the 1970s .............................................................8

Figure 3. Image and elevation model of the old airport runway ...........................................................................10

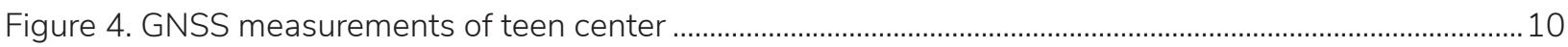

Figure 5. GNSS measurement of the metal skirting placed around the school base..........................................14

Figure 6. Photos of Kotlik immediately after November 9, 2011, flood and measurement of boardwalk......16

Figure 7. Elevation of the main, elevated boardwalk ............................................................................................

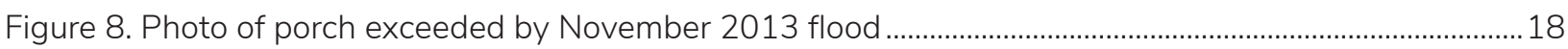

Figure 9. GNSS measurement of ground at new building by tank farm ..............................................................20

Figure 10. GNSS measurement of the base of the ramp at the Alaska Commercial store...............................21

Figure 11. GNSS measurement of step where March 2019 flood reached .........................................................23

Figure 12. GNSS measurement of flooded ground near erosion camera ................................................................23

Figure 13. Flood staff installed on power pole

\section{Tables}

Table 1. Summary of infrastructure heights and flood categories ...........................................................................2

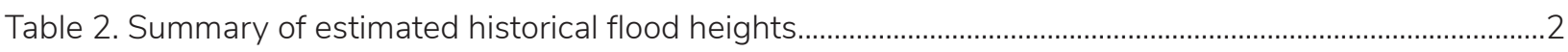

Table 3. Specifications of elevation models available for Kotlik ................................................................................

Table 4. Tidal datum for Kotlik .......................................................................................................................

Table 5. Flood parameters used to estimate the spring 1964 flood ……..................................................................7

Table 6. Flood parameters used to estimate the November 1975 flood ....................................................................8

Table 7. Flood parameters used to estimate the August 19,1978, flood ..............................................................9

Table 8. Flood parameters used to estimate the 1987 flood ................................................................................11

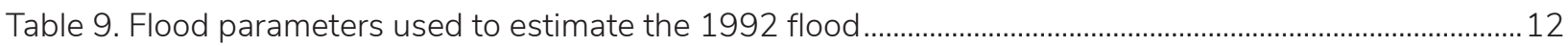

Table 10. Flood parameters used to estimate the November 8, 2003, flood .....................................................13

Table 11. Flood parameters used to estimate the May 25, 2009, flood ................................................................ 15

Table 12. Flood parameters used to estimate the November 9, 2011, flood ....................................................17

Table 13. Flood parameters used to estimate the November 12, 2017, flood.....................................................20

Table 14. Flood parameters used to estimate the November 21, 2017, flood......................................................21

\section{Appendices}

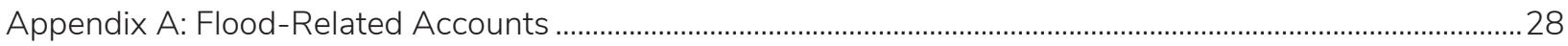

Appendix B: Flood Category Calculation Figures ……...............................................................................................54 


\title{
COASTAL FLOOD IMPACT ASSESSMENTS FOR ALASKA COMMUNITIES-KOTLIK
}

\author{
Richard M. Buzard ${ }^{1}$, Jacquelyn R. Overbeck ${ }^{1}$, Marvin M. Turner ${ }^{1}$, and Jessica E. Christian²
}

\section{OVERVIEW}

This report is an assessment of the historical flood record and flood impact levels for the community of Kotlik, Alaska. Methods used to evaluate historical floods and designate flood impact elevations (minor, moderate, or major; as defined by the National Weather Service) are described in detail in an overview report (Buzard and others, 2021a). This community-specific report has three sections: data description, historical flood record, and flood impact categories. Flood and infrastructure heights are relative to local mean higher high water (MHHW). All estimated uncertainties are reported to a 95 percent confidence interval. Quoted text from the sources used to estimate flood heights can be found in appendix A. Appendix B has tables and figures used to determine flood category heights, including relevant results from our global navigation satellite system (GNSS) survey conducted in July 2021.

\section{SUMMARY}

Flood categories and related infrastructure heights are listed in table 1 , and estimated flood heights are listed in table 2 . There have been two state or federal disaster declarations from coastal flooding reported at Kotlik in 2011 and 2013 (City and Village of Kotlik, 2019). Although 2011 was the first declared disaster, major floods have occurred for decades. From 1952 to 2021, Kotlik experienced at least 32 coastal flood events (29 from storm surge, one from ice jam, and two with unverified cause). Of these reported events, we estimate the peak still water elevations of 28 floods. At the time of occurrence, these events caused 13 minor, seven moderate, and eight major floods. Although many homes are higher than in the past, floods reaching the height of historical events would still

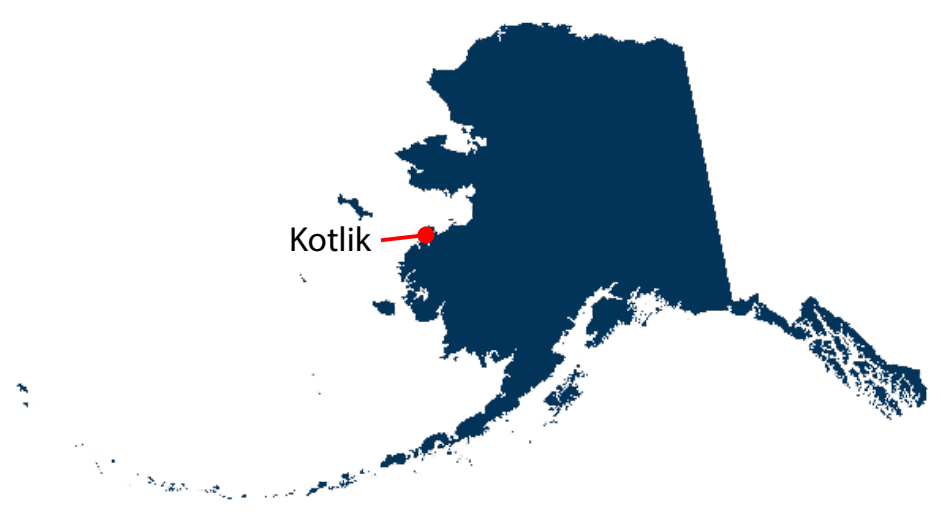

cause similar impacts today. The highest recorded flood occurred on November 10, 1974, reaching a still water height of $7.7 \pm 0.4 \mathrm{ft}$ MHHW.

\section{DATA}

Mapped data are used to interpret flood elevations from historical photographs and accounts. This section describes available data used to assess flooding for Kotlik.

\section{Digital Elevation Models and Orthoimagery}

High-resolution and accuracy elevation models are required to measure flood heights. Three digital elevation models were collected at Kotlik (table 3). A digital surface model (DSM) and orthoimagery were collected in 2015 (Overbeck and others, 2016) and 2021 (Buzard and others, 2021b). A digital terrain model (DTM) derived from lidar was collected in 2019 (Herbst and Daanen, 2020).

\section{First Floor Survey}

CRW Engineering Group, LLC (CRW, unpub. data, 2021) surveyed first floor heights in the NAVD88 (GEOID12B) datum. We convert these heights to the local tidal datum and use where applicable (table B1).

${ }^{1}$ Alaska Division of Geological \& Geophysical Surveys, 3354 College Rd., Fairbanks, Alaska 99709-3707.

2 University of Alaska Fairbanks Arctic Coastal Geoscience Lab, P.O. Box 755780, Fairbanks, AK 99775 


\section{Coastal Flood Impact Map Kotlik, Alaska}
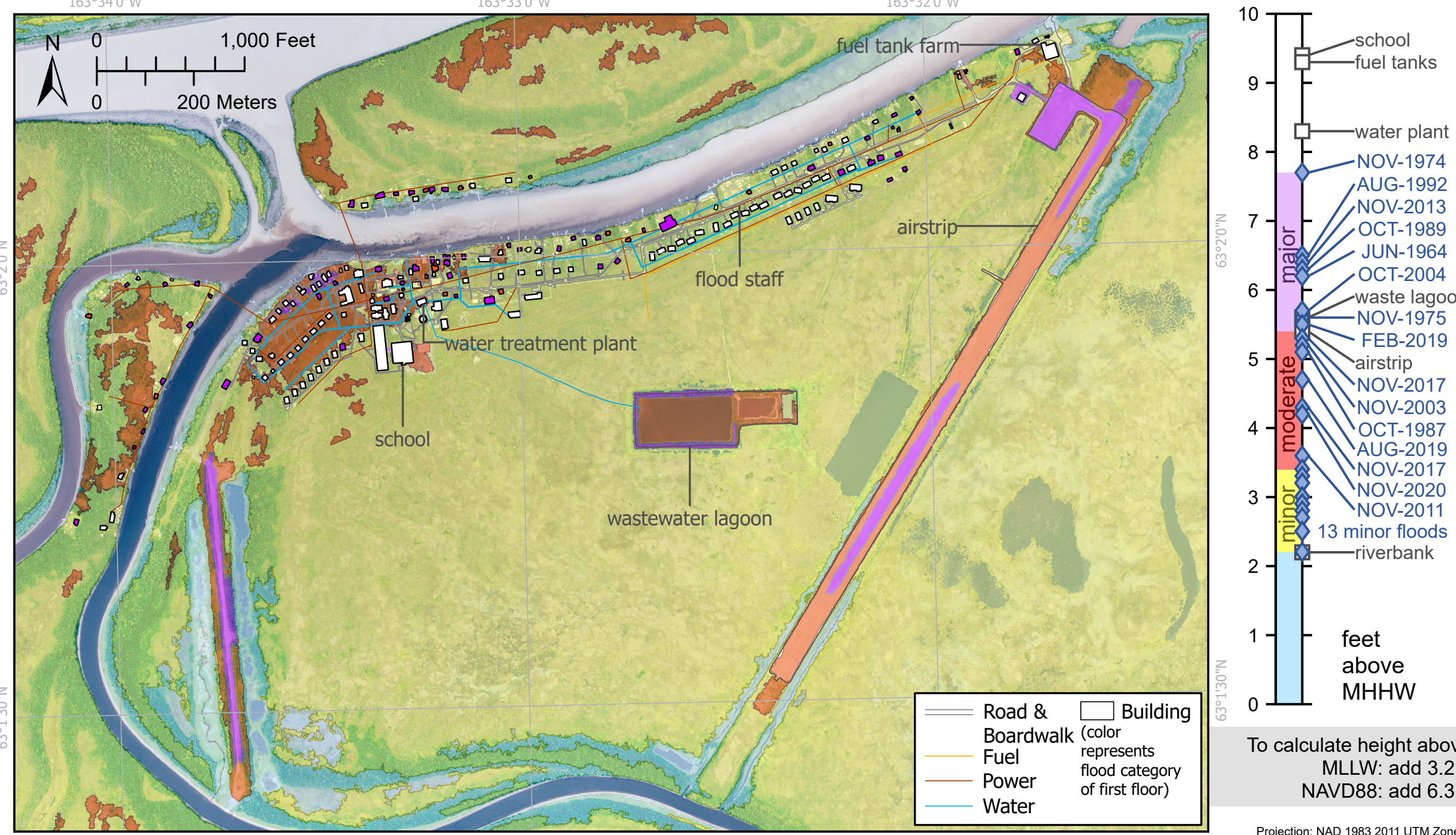

To calculate height above MLLW: add $3.2 \mathrm{ft}$ NAVD88: add $6.3 \mathrm{ft}$

Projection: NAD 19832011 UTM Zone 3N Orthoimagery available from elevation.alaska.gov

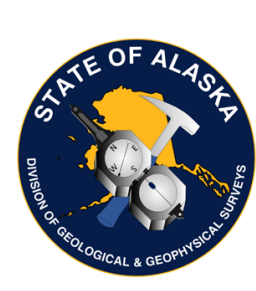

STATE OF ALASKA

DEPARTMENT OF NATURAL RESOURCES

DIVISION OF GEOLOGICAL \& GEOPHYSICAL SURVEYS

The State of Alaska makes no expressed or implied warranties (including warranties for merchantability and ittiness) with respect to the character, functions, or capabilities of the electronic data or products or their appropriateness for any user's purposess. In no event will the State of Alaska be liable for any incidental, from the use of the electronic sevices or products or any failure thereof or otherwise in no event will the Sther of Alaska's liability to the Requestor or anyone else exceed the fee paid for the electronic service or product. website: dggs.alaska.gov

Houses or infrastructure may have moved since DCRA Major Flooding is defined to have extensive inundation of structures and roads.
Significant evacuations of people and/or transfer of property to higher elevations are necessary.

Moderate Flooding is defined to have some inundation of structures and roads near the water Some evacuations of people and/or transfer of property to higher elevations may be necessary.

Minor Flooding is defined to have minimal or no property damage, but possibly some public threat. 

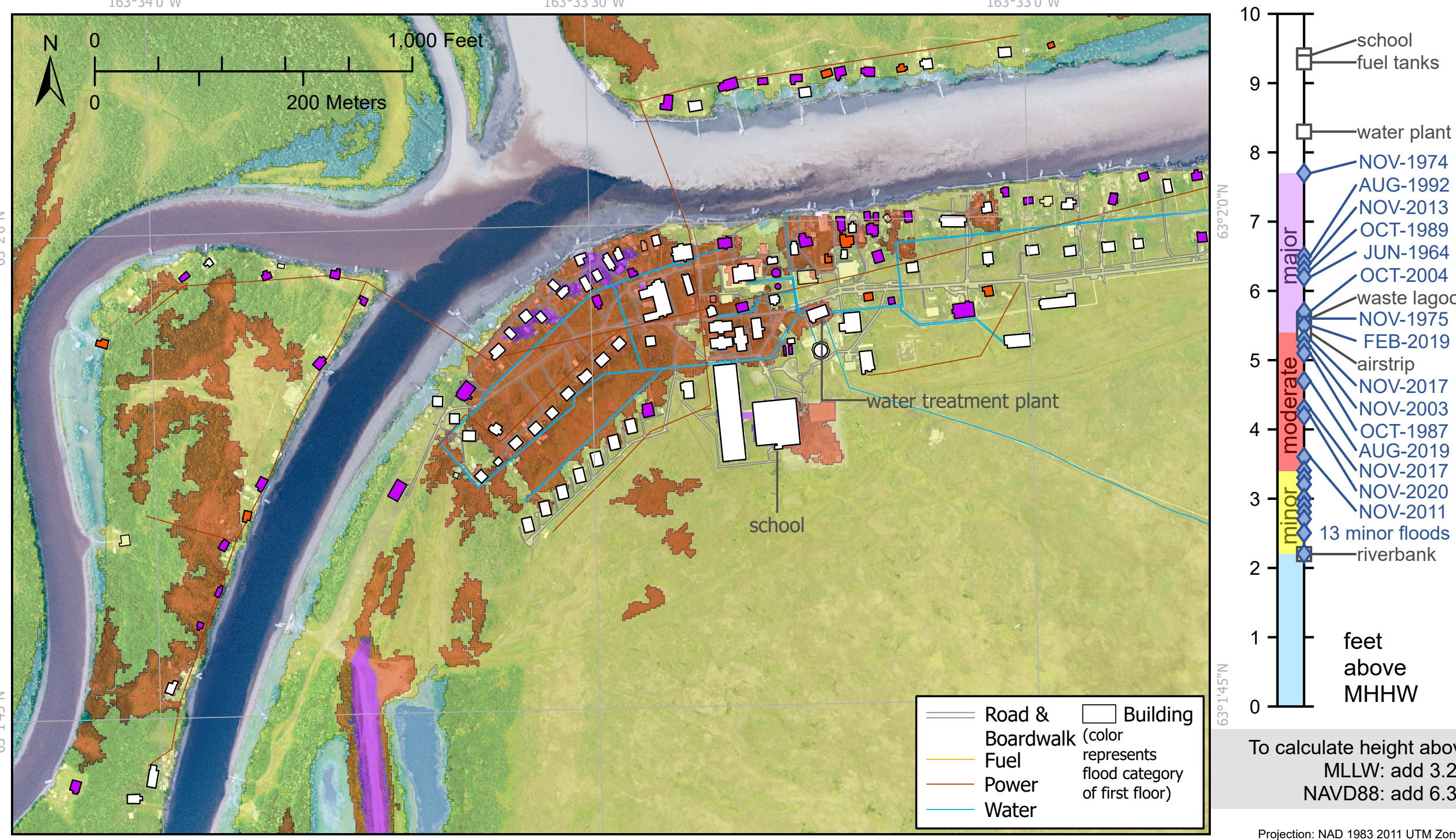

To calculate height above MLLW: add $3.2 \mathrm{ft}$ NAVD88: add $6.3 \mathrm{ft}$

Projection: NAD 19832011 UTM Zone 3N Orthoimagery available from elevation.alaska.gov

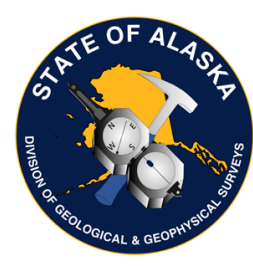

STATE OF ALASKA

DEPARTMENT OF NATURAL RESOURCES

DIVISION OF GEOLOGICAL \& GEOPHYSICAL SURVEYS

The State of Alaska makes no expressed or implied warranties (including warranties for merchantability and thess) With respect to the character, functions, or capabilities of the electronic data or products or their appropriateness for any user's purposes. In no event will the State of Alaska be llable for any incidental, from the use of the electronic senices or products or any failure thereof or otherwise in no or enty whether of Alaska's liability to the Requestor or anyone else exceed the fee paid for the electronic service or product. website: dggs.alaska.gov

Houses or infrastructure may have moved since DCR Major Flooding is defined to have extensive inundation of structures and roads.
Significant evacuations of people and/or transfer of property to higher elevations are necessary.

Moderate Flooding is defined to have some inundation of structures and roads near the water Some evacuations of people and/or transfer of property to higher elevations may be necessary.

Minor Flooding is defined to have minimal or no property damage, but possibly some public threat. 


\section{Coastal Flood Impact Map Kotlik, Alaska}
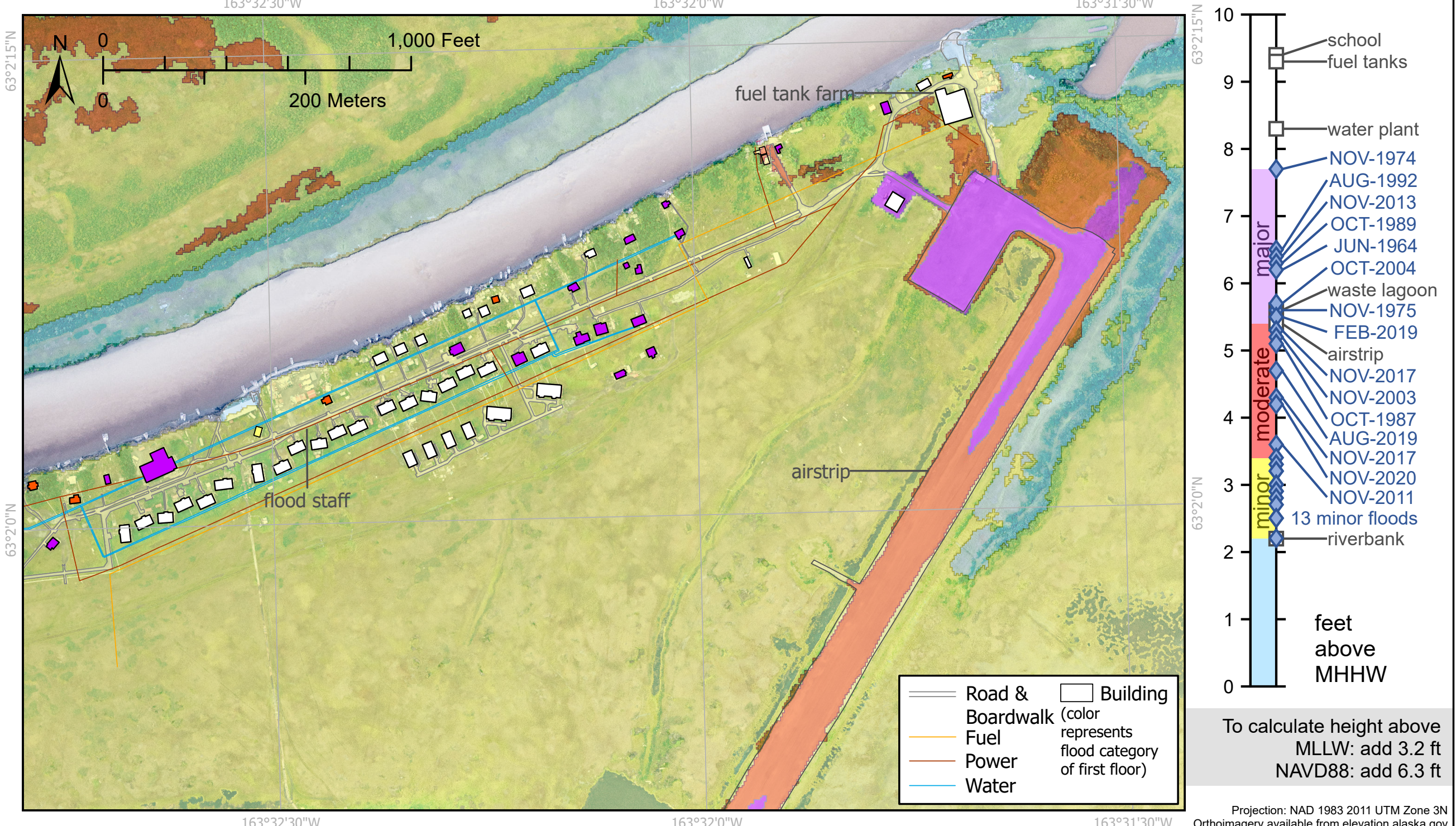

\section{STATE OF ALASKA}

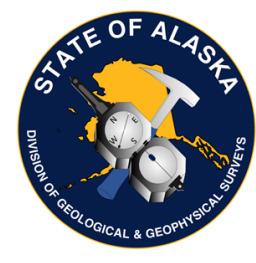

DEPARTMENT OF NATURAL RESOURCES

DIVISION OF GEOLOGICAL \& GEOPHYSICAL SURVEYS

The State of Alaska makes no expressed or implied warranties (including warranties for merchantability and thiness) with respect to the character, finchlions, of capabilities of the electronic data or products or their appropriateness for any user's purposes. In no event will the State of Alaska be liable for any incidental, from the use of the electronic sevices or products or any failure thereof or otherwise in no event will the Sther of Alaska's liability to the Requestor or anyone else exceed the fee paid for the electronic senvice or product. website: dggs.alaska.gov
Houses or if $103^{\circ} 3130$ Orthoimagery available from elevation.alaska.gov

Major Flooding is defined to have extensive inundation of structures and roads.

Significant evacuations of people and/or transfer of property to higher elevations are necessary.

Moderate Flooding is defined to have some inundation of structures and roads near the water. Some evacuations of people and/or transfer of property to higher elevations may be necessary.

Minor Flooding is defined to have minimal or no property damage, but possibly some public threat. This work was funded by Bureau of Indian Affairs Tribal Resilience Program through a collaborative project with the Native Village
of Bill Moore's Slough. 
Table 1. Summary of infrastructure heights and flood categories. Purple = major, red = moderate, yellow $=$ minor. Gray represents infrastructure not expected to be impacted by coastal flooding. No infrastructure is considered subject to wave runup because there is no broadly sloping beach along Kotlik.

\section{Elevation Feature}

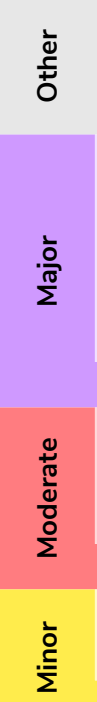

Evacuation center (school)

Fuel tank farm platform

Water treatment plant

Highest recorded flood

Several buildings (flooded 1 or more $\mathrm{ft}$ )

Wastewater lagoon

Lowest residences (flooded 0 to $1 \mathrm{ft}$ )

Airstrip covered

\section{Major}

Access way to lager parts of town

Lowest building

Airstrip use or access

\section{Moderate}

Access road threatened

Low-lying property
Elevation (ft MHHW)

9.4

9.3

8.3

7.7

6.0

5.6

5.5

5.4

5.4

4.2

4.1

3.5

3.5

3.0

2.2

2.2
Vertical Uncertainty (ft)

0.1

0.1

0.1

0.4

0.1

1.3

0.5

1.1

1.1

0.5

0.1

0.5

0.5

0.5

0.6

0.6

Table 2. Summary of historical storm heights. Purple = major, red = moderate, yellow $=$ minor. The categories are based on current infrastructure conditions, not the conditions when the storm occurred.

\section{Floods Estimated}

\begin{tabular}{ccc}
\hline Flood Date & $\begin{array}{c}\text { Elevation } \\
\text { (ft MHHW) }\end{array}$ & $\begin{array}{c}\text { Vertical } \\
\text { Uncertainty (ft) }\end{array}$ \\
\hline 1974-NOV-10 & 7.7 & 0.4 \\
1992-AUG-18 & 6.5 & 1.0 \\
2013-NOV-06 & 6.4 & 1.1 \\
1989-OCT-07 & 6.3 & 1.1 \\
\hline 1964-JUN & 6.2 & 0.5 \\
\hline 1975-NOV & 5.6 & 1.0 \\
\hline 2004-OCT-18 & 5.7 & 0.5 \\
\hline 2019-FEB-12 & 5.5 & 0.5 \\
\hline 2017-NOV-12 & 5.3 & 0.5 \\
\hline 2003-NOV-08 & 5.2 & 1.2 \\
\hline 1987-OCT-14 & 5.1 & 1.0 \\
\hline 2019-AUG-03 & 4.7 & 0.5 \\
\hline 2017-NOV-21 & 4.3 & 0.5 \\
\hline 2020-NOV-11 & 4.2 & 0.5 \\
\hline 2011-NOV-09 & 3.6 & 0.7 \\
\hline 2019-JUL-03 & 3.4 & 0.5 \\
\hline 2019-OCT-04 & 3.3 & 0.5 \\
\hline 1978-AUG-19 & 3.2 & 1.2 \\
\hline
\end{tabular}

\section{Flood Date Elevation Vertical (ft MHHW) Uncertainty (ft)}

\begin{tabular}{cll}
\hline 2005-JAN & 3.2 & 0.8 \\
\hline 2009-MAY-25 & 3.0 & 0.5 \\
\hline $2019-M A R-26$ & 3.0 & 0.5 \\
\hline $2017-O C T-13$ & 2.9 & 0.5 \\
\hline $2018-N O V-09$ & 2.9 & 0.5 \\
\hline $2017-J A N-01$ & 2.8 & 0.7 \\
\hline $2019-$ FEB-28 & 2.7 & 0.8 \\
\hline $2017-D E C-18$ & 2.5 & 0.6 \\
\hline 1965-Fall & 2.5 & 1.0 \\
\hline $2003-N O V-26$ & 2.2 & 1.0
\end{tabular}

Floods Not Estimated

1952-NOV-10

2000-FEB-04

2002-ОСТ-08

2006-OCT-08 


\section{Tidal Datum}

The local tidal datum collected for Kotlik is used to convert orthometric heights to MHHW for this report (station 9467861; National Oceanographic and Atmospheric Administration Center for Operational Oceanographic Products and Services [NOAA CO-OPS], 2021; table 4).

\section{FLOOD IMPACT CATEGORIES}

Flood impact categories are used by the National Weather Service to define and communicate flood risk to the public. The categories are designated as minor, moderate, and major. A flood advisory is issued when a storm is forecast to cause minor flooding, while a flood warning is issued for moderate or major flooding. Definitions of minor, moderate, and major flooding are provided below followed by the information used to establish the elevation thresholds for each category at Kotlik. Elevation thresholds and locations mentioned in the narrative below have been mapped using the DSM (map sheet Kotlik, previous page).

Minor Flooding: Minimal or no property damage, but possibly some public threat.

Moderate Flooding: Some inundation of structures and roads near the water. Some evacuations of people and/or transfer of property to higher elevations may be necessary.

Major Flooding: Extensive inundation of structures and roads. Significant evacuations of people and/or transfer of property to higher elevations are necessary.

Table 3. Specifications of elevation models available for Kotlik.

\begin{tabular}{cccr} 
& Photogrammetric DSM & Photogrammetric DSM & DTM (lidar) \\
\hline Collection date & 2015-AUG-23 & 2021-JUL-10 & 2019-AUG-17 \\
\hline Elevation type & Surface & Surface & Bare earth \\
\hline Vertical datum & NAVD88 (GEOID12B) & NAVD88 (GEOID12B) & NAVD88 (GEOID12B) \\
\hline Ground sample distance & $0.66 \mathrm{ft}(0.20 \mathrm{~m})$ & $0.23 \mathrm{ft}(0.07 \mathrm{~m})$ & $1.64 \mathrm{ft}(0.50 \mathrm{~m})$ \\
\hline Accuracy & $1.61 \mathrm{ft}(0.49 \mathrm{~m})$ & $0.20 \mathrm{ft}(0.06 \mathrm{~m})$ & $\begin{array}{c}0.26 \mathrm{ft}(0.08 \mathrm{~m})(\mathrm{non}-\mathrm{vegetated}) \\
0.82 \mathrm{ft}(0.25 \mathrm{~m})(\mathrm{vegetated})\end{array}$
\end{tabular}

Table 4. Tidal datum for Kotlik from NOAA CO-OPS (2021).

\begin{tabular}{cccc} 
Tidal Datum & Abbreviation & ft MHHW & m NAVD88 \\
\hline Mean Higher High Water & MHHW & 0.00 & 1.913 \\
\hline Mean High Water & MHW & -0.86 & 1.649 \\
\hline Mean Tide Level & MTL & -1.95 & 1.318 \\
\hline Mean Sea Level & MSL & -2.05 & 0.985 \\
\hline Mean Low Water & MLW & -3.04 & 0.932 \\
\hline Mean Lower Low Water & MLLW & -3.22 & 0.000
\end{tabular}




\section{Other Infrastructure}

\section{Evacuation center (school): $9.4 \pm 0.1 \mathrm{ft}$ MHHW}

The school first floor height is $9.4 \pm 0.1 \mathrm{ft}$ MHHW (table B1). This is above observed flood levels.

Fuel tanks: $9.3 \pm 0.1 \mathrm{ft}$ MHHW

The fuel tanks are on a raised platform at $9.3 \pm 0.1 \mathrm{ft} \mathrm{MHHW} \mathrm{(table} \mathrm{B1).} \mathrm{This} \mathrm{is} \mathrm{above} \mathrm{observed} \mathrm{flood} \mathrm{levels.}$ Drinking water source: $8.3 \pm 0.1 \mathrm{ft} \mathrm{MHHW}$

Drinking water is piped from the river overland to the water treatment plant. The water treatment plant is $8.3 \pm 0.1 \mathrm{ft} \mathrm{MHHW}$, and the water tank is $8.9 \pm 0.1 \mathrm{ft} \mathrm{MHHW} \mathrm{(table} \mathrm{B1).}$

\section{Major flooding: $5.4+1.1 \mathrm{ft} \mathrm{MHHW}$}

\section{Several buildings (flooded 1 or more $\mathrm{ft}$ ): $6.0 \pm 0.1 \mathrm{ft}$ MHHW}

Flooding of $6.0 \pm 0.1 \mathrm{ft} \mathrm{MHHW}$ can reach the first floor of 20 residences, 4 commercial buildings, and 1 public building (fig. B1). Some would have over $1 \mathrm{ft}$ of water inside.

\section{Wastewater facility: $5.6 \pm 1.3 \mathrm{ft}$ MHHW}

The wastewater lagoon has three sections. The hauled waste lagoon barrier averages $4.6 \pm 1.1 \mathrm{ft} \mathrm{MHHW}$ (fig. B2). The larger lagoon, where wastewater is piped in, has a barrier averaging $10.0 \pm 1.4 \mathrm{ft} \mathrm{MHHW}$ as well as a fence to help contain material (fig. B2). Floods overtopping the lower lagoon have the potential to spread effluent into town. However, floods reaching near $4.6 \mathrm{ft} \mathrm{MHHW} \mathrm{have} \mathrm{only} \mathrm{caused} \mathrm{minor}$ to moderate impacts, and we found no reports of the lagoon being breached. The 2013 flood $(6.4 \pm 1.1$ $\mathrm{ft} \mathrm{MHHW}$ ) is the only reported event to have breached the lagoon. The lagoon is approximately 1500 $\mathrm{ft}$ from the riverbank, so floods may be slightly lower this far inland than at the riverbank where most of Kotlik is situated. We estimate water reaching $1.0 \pm 0.5 \mathrm{ft}$ above the barrier height can begin to contaminate floodwaters. This is $5.6 \pm 1.2 \mathrm{ft} \mathrm{MHHW}$, using the root-sum-square (RSS) error of uncertainties.

\section{Lowest residences (flooded 0 to $1 \mathrm{ft}$ ): $5.5 \pm 0.5 \mathrm{ft} \mathrm{MHHW}$}

The lowest residence is $4.1 \pm 0.1 \mathrm{ft} \mathrm{MHHW}$ and the next lowest is $5.0 \mathrm{ft} \mathrm{MHHW}$. Water reaching $5.5 \pm$ $0.5 \mathrm{ft}$ can flood between 1 and 20 residences with about $1 \mathrm{ft}$ of water (fig. B1).

\section{Airstrip covered: $5.4 \pm 1.1 \mathrm{ft} \mathrm{MHHW}$}

The airstrip elevation averages $5.4 \pm 1.1 \mathrm{ft} \mathrm{MHHW} \mathrm{(fig.} \mathrm{B3).}$

\section{Moderate flooding: $3.5 \pm 0.5 \mathrm{ft}$ MHHW}

\section{Access way to larger parts of town: $4.2 \pm 0.5 \mathrm{ft} \mathrm{MHHW}$}

Flood events reaching $4.2 \pm 0.5 \mathrm{ft} \mathrm{MHHW}$ tend to begin covering boardwalks and flooding low sections, impeding travel (see August 2019 and November 2020 floods).

\section{Lowest building: $4.1 \pm 0.1 \mathrm{ft} \mathrm{MHHW}$}

Of residences, public, and commercial buildings, the lowest is $4.1 \pm 0.1 \mathrm{ft} \mathrm{MHHW} \mathrm{(fig.} \mathrm{B1).}$

\section{Airstrip use or access: $3.5 \pm 0.5 \mathrm{ft}$ MHHW}

The lowest section of road to the airstrip is $2.0 \pm 0.1 \mathrm{ft} \mathrm{MHHW} \mathrm{(fig.} \mathrm{B4).} \mathrm{Water} \mathrm{reaching} 1.5 \pm 0.5 \mathrm{ft}$ above this can make the road impassable by four-wheeler. This is a total water height of $3.5 \pm 0.5 \mathrm{ft} \mathrm{MHHW}$. 


\section{Minor Flooding: $2.2 \pm 0.6 \mathrm{ft} \mathrm{MHHW}$}

\section{Access road threatened: $3.0 \pm 0.5 \mathrm{ft}$ MHHW}

Water reaching $3.0 \pm 0.5 \mathrm{ft} \mathrm{MHHW}$ will cover the road to the airport, but it is considered passable (see May 2009 flood).

\section{Beach property: $2.2 \pm 0.6 \mathrm{ft}$ MHHW}

Boats, fishing equipment, and property left on the ground are the most common damages during minor flood events. Water exceeding the riverbank can cause damage this property, especially if there is high flow, debris, or broken sea ice. The riverbank is $2.2 \pm 0.6 \mathrm{ft} \mathrm{MHHW} \mathrm{(table} \mathrm{B2;} \mathrm{fig.} \mathrm{B5).}$

\section{HISTORICAL FLOOD RECORD}

The historical flood record for Kotlik, Alaska is listed here from the earliest recorded flood (November 1952) to the most recent (up to July 2021). The sources used in evaluating each flood are listed along with a summary of the relevant information found within. This historical information is used to estimate the flood height where possible. This flood record depends on information that was available to the public and shared with DGGS staff during the July 2021 survey. Relevant survey data is provided in Appendix B, table B1. It is possible that storm and flood events have occurred that are not reported here. See Appendix A for the direct quotations from each source that are used to evaluate these floods.
The earliest record of population at Kotlik was documented by the 1880 U.S. Census Bureau, which reported eight residents (U.S. Census Bureau, 1880). In the late 1950s, the Bureau of Indian Affairs chose Kotlik for the location of the regional school, resulting in a merging of nearby communities (Chaneliak, Hamilton, Bill Moore's Slough, and Pastolik) to create the modern-day community of Kotlik (Kotlik CEDS Committee, 2004; Native Village of Bill Moore's Slough [BMS], oral commun., 2021). Before the 1980s, most residences were built directly on the ground. New structures were elevated on posts and some existing buildings were raised, reducing evacuations and overall flood impacts (BMS, oral commun., 2021).

\section{2-NOV-10 | No water level estimate}

Reference

BMS, oral commun. (2021)

\section{Source information relevant to flood height}

Kotlik was a seasonal fish camp, and the BIA school was not built yet. There were probably flood impacts, but no one was there at the time.

City and Village of Kotlik (2019)

City of Kotlik (2013)

Kotlik Tribal Council (2008)

Kotlik Tribal Council (2010)

URS (2007)

Major flooding at Chaneliak

The November 10, 1952, flood caused major impacts in Chaneliak, six miles east and downriver from Kotlik (URS, 2007). The flood likely affected the Kotlik area, but there were no reports because people were not at the location (BMS, oral commun., 2021). The flood did not appear to be caused by storms, so sources attribute it to a tsunami. On November 4, 1952 (6 days earlier), a magnitude 9.0 earthquake occurred in Kamchatka, Russia. This event generated a tsunami that caused minor damage in Aleutian communities and reached as far as Hawaii. It is possible this event caused flooding in the Kotlik area, although the recorded dates are six days apart. The flood date may have been recorded incorrectly. Aftershocks or delayed submarine landslides can also generate tsunami. Regardless of the cause, without descriptions of impacts to Kotlik the flood height cannot be estimated. 


\section{4-JUN | $6.2 \pm 1.0 \mathrm{ft} \mathrm{MHHW}$}

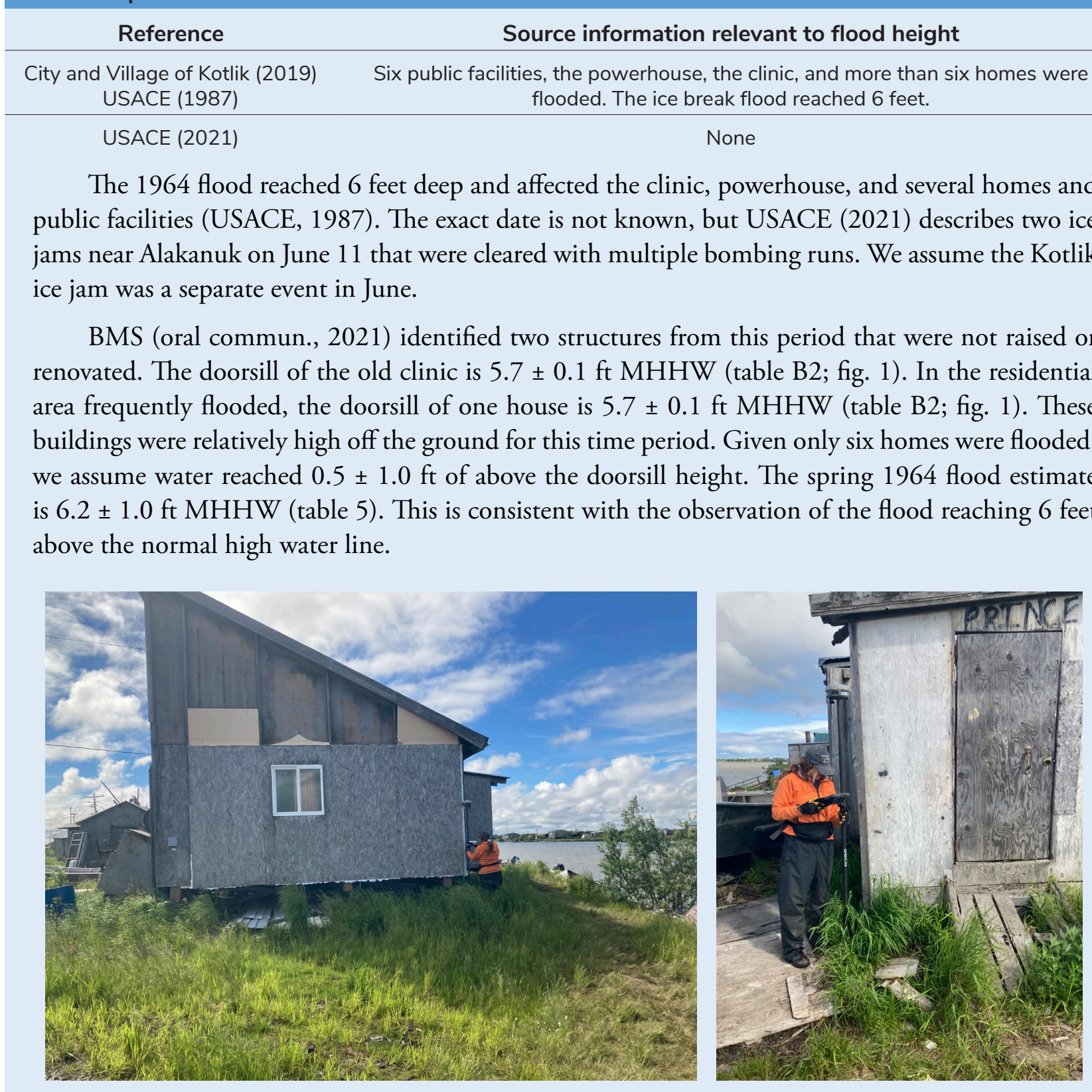

Figure 1. GNSS floor measurements of the old clinic (left) and a residence from the 1970s (right). 
Table 5. Flood parameters used to estimate the spring 1964 flood. Uncertainty is calculated using the RSS error.

\begin{tabular}{l|l}
\multicolumn{1}{c}{ Feature } & \multicolumn{1}{c}{ Flooding of structures } \\
\hline Feature represents & $\begin{array}{l}\text { Highest water } \\
\text { Still water }\end{array}$ \\
Water level type & 6.2 \\
\hline Estimate of height (ft MHHW) & 0.5 \\
\hline Uncertainty of estimate (ft) & 0.1 \\
Uncertainty of GNSS (ft) & $6.2 \pm 0.5$
\end{tabular}

\section{5 fall | $2.5 \pm 1.0 \mathrm{ft} \mathrm{MHHW}$}

\begin{tabular}{l} 
Reference \\
\begin{tabular}{c} 
Source information relevant to flood height \\
\hline BMS, oral commun. (2021)
\end{tabular} None $3 \mathrm{ft}$ of flooding \\
\hline USACE (1987) \\
This flood likely caused only 2 to $3 \mathrm{ft}$ of flooding above MHHW because, while notable, no \\
specific impacts are reported (BMS, oral commun., 2021). We increase uncertainty to $1.0 \mathrm{ft}$ given the \\
limited source data. We estimate the 1965 fall flood reached $2.5 \pm 1.0 \mathrm{ft}$ MHHW.
\end{tabular}

\section{4-NOV-10 | $7.7 \pm 0.4 \mathrm{ft}$ MHHW}

Reference

City and Village of Kotlik (2019) USACE (1982)

City of Kotlik (2013) URS (2007)

NOAA (1974)

USACE (2011)

USACE (2012)

Wise and others (1981)

\section{Source information relevant to flood height}

City limits flooded to $2 \mathrm{ft}$ or more except for the cemetery. Approximately nine homes flooded.

"This record rainfall flood is the most severe the community ever experienced. The entire village was inundated to a depth of 4 feet."

Water damage to several houses. Moderate structural damage to two houses and loss of property in lawns.

High water elevation survey

Flood height of $4.30 \mathrm{~m}$ NAVD88 (GEOID09)

None

The November 1974 storm caused widespread flooding in western Alaska and is considered the worst flood that Kotlik has endured (City and Village of Kotlik, 2019). The entire village was inundated in 4 feet of water (URS, 2007) and at least nine houses sustained water damage (NOAA, 1974). USACE (2011) performed a survey of first floor elevations and high water mark estimates using a Temporary Benchmark in 1995. USACE (2012) measured the 1995 survey into NAVD88 
using GEOID09. We convert these heights to NAVD88 (GEOID12B) using VDATUM Online (found at vdatum.noaa.gov/vdatumweb/) and to the local tidal datum (table 4). USACE (2012) estimates the survey accuracy is $0.338 \mathrm{ft}(0.103 \mathrm{~m})$. The VDATUM conversion uncertainty is $0.19 \mathrm{ft}$ $(0.059 \mathrm{~m})$. The total uncertainty is $0.39 \mathrm{ft}(0.12 \mathrm{~m})$. We estimate the November 1974 flood reached $7.7 \pm 0.4 \mathrm{ft} \mathrm{MHHW}$. This height is consistent with reports of water reaching 2 to $4 \mathrm{ft}$ depth (above ground level).

\section{5-NOV | $5.6 \pm 1.0 \mathrm{ft}$ MHHW}

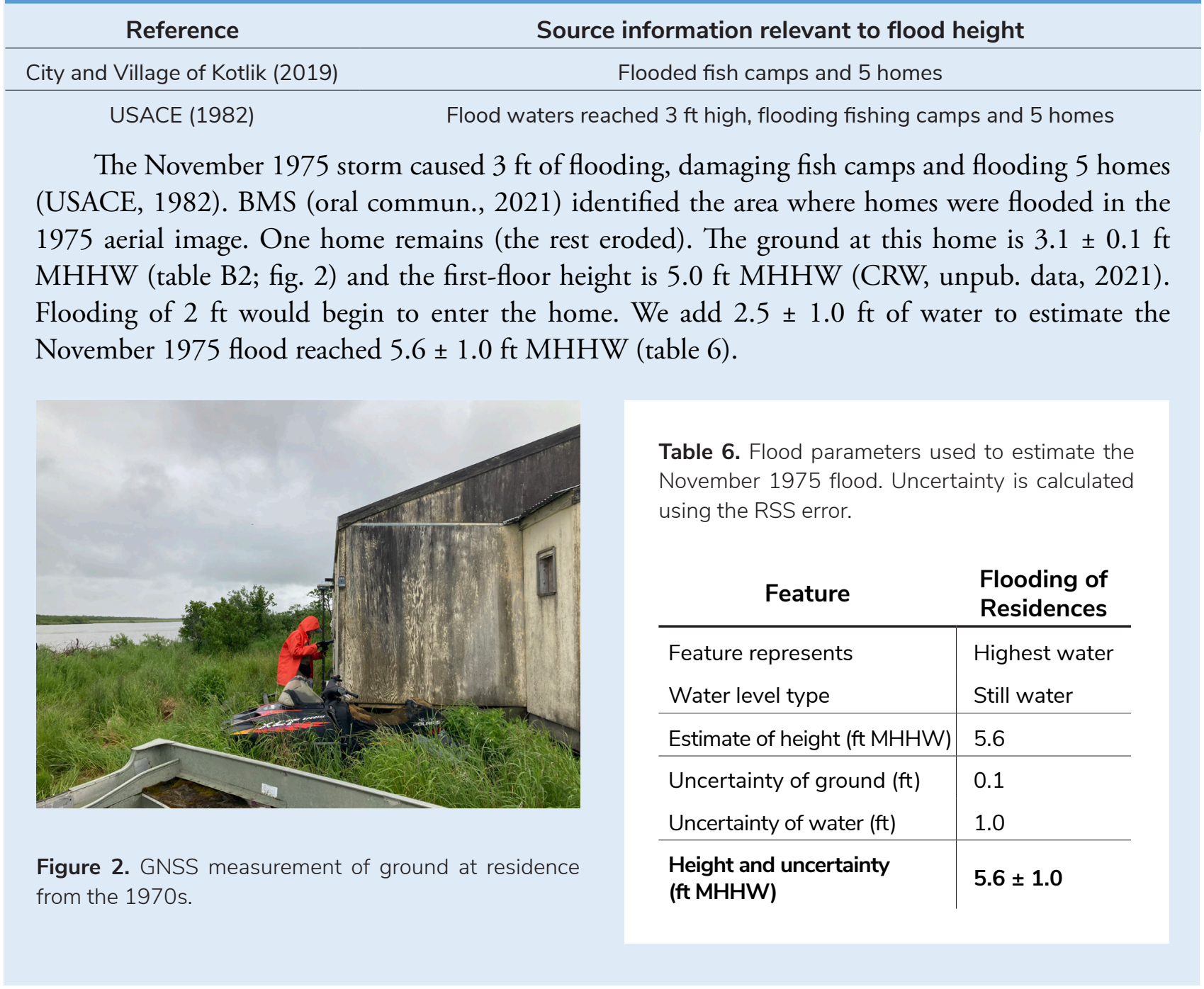




\section{8-AUG-19 | $3.2 \pm 1.2 \mathrm{ft}$ MHHW}

Reference

Wise and others (1981)
Source information relevant to flood height

“\$50,000 Damage to boats, motors, fishing equipment and fuel lost to residents of Kotlik and Emmonak."

The August 1978 storm caused damage to boats and fishing equipment in Kotlik (Wise and others, 1981). Given the uncommon summer timing, more damage may have occurred because fishing equipment was not stored for the fall and winter storm season. It is not clear if damage occurred only to boats (and equipment in boats) parked in the river or those on land, too. There are no reports of damage to homes, so we assume water reached at least to the bank but not high enough to flood several structures. The average riverbank height is $2.2 \pm 0.6 \mathrm{ft} \mathrm{MHHW} \mathrm{(table} \mathrm{B2;} \mathrm{fig.} \mathrm{B5).}$ Water could have reached up to $2 \mathrm{ft}$ above the bank without flooding residences. We add $1.0 \pm 1.0 \mathrm{ft}$ of water to estimate the August 1978 flood reached $3.2 \pm 1.2 \mathrm{ft}$ MHHW (table 7).

Table 7. Flood parameters used to estimate the August 19, 1978, flood. Uncertainty is calculated using the RSS error.

Feature

Flooding over riverbank

\begin{tabular}{l|l}
\hline Feature represents & $\begin{array}{l}\text { Highest water } \\
\text { Still water }\end{array}$ \\
Water level type & 3.2 \\
\hline Estimate of height (ft MHHW) & 0.6 \\
\hline Uncertainty of ground (ft) & 1.0 \\
Uncertainty of water (ft) & $3.2 \pm 1.2$
\end{tabular}

\section{7-OCT-14 | $5.1 \pm 1.0 \mathrm{ft}$ MHHW}

\section{Reference}

City of Kotlik (2013)

City and Village of Kotlik (2019) URS (2007)

NOAA (1987)

USACE (2011)

\section{Source information relevant to flood height}

The riverbank overflowed and water reached a depth of 2 feet throughout Kotlik. "Almost all houses were affected, as well as the Teen Center and several public buildings. The old and new runways were the only parts of town to not be affected by the flood."

October 14 storm flooded Sheldon Point (now Nunam lqua), Toksook Bay, and Emmonak Water in the community was about $2 \mathrm{ft}$ deep during the 1987 flood.

The exact date of the 1987 flood is not specified in Kotlik resources but is likely the October 14 storm that flooded nearby communities (NOAA, 1987). The 1987 storm caused community-wide flooding of two feet (URS, 2007). In the 1980s, Kotlik was elevating homes, so only the log cabins built in the 1950s and 1960s were built directly on the ground (BMS, oral commun., 2021). The flood "affected" almost all residences, but this likely means damage to outdoor property because 2 feet of flooding was not high enough to enter most residences in 1987 (BMS, oral commun., 2021). The old and new runway were the only parts of town not flooded. The height of the old airport 
runway averages $6.5 \pm 1.1 \mathrm{ft}$ MHHW (fig. 3), and the new runway averages $5.4 \pm 1.1 \mathrm{ft}$ MHHW (fig. B3). BMS (oral commun., 2021) explains that flood water has never entered the teen center. The ground at the teen center is $3.1 \mathrm{ft}$ MHHW and the floor is $6.8 \pm 0.1 \mathrm{ft}$ MHHW (table B2; fig. 4). Given these observations, water likely reached as high as $2.0 \pm 1.0 \mathrm{ft}$ above the teen center ground height. We estimate the October 1987 flood reached $5.1 \pm 1.0 \mathrm{ft} \mathrm{MHHW}$ (table 8).
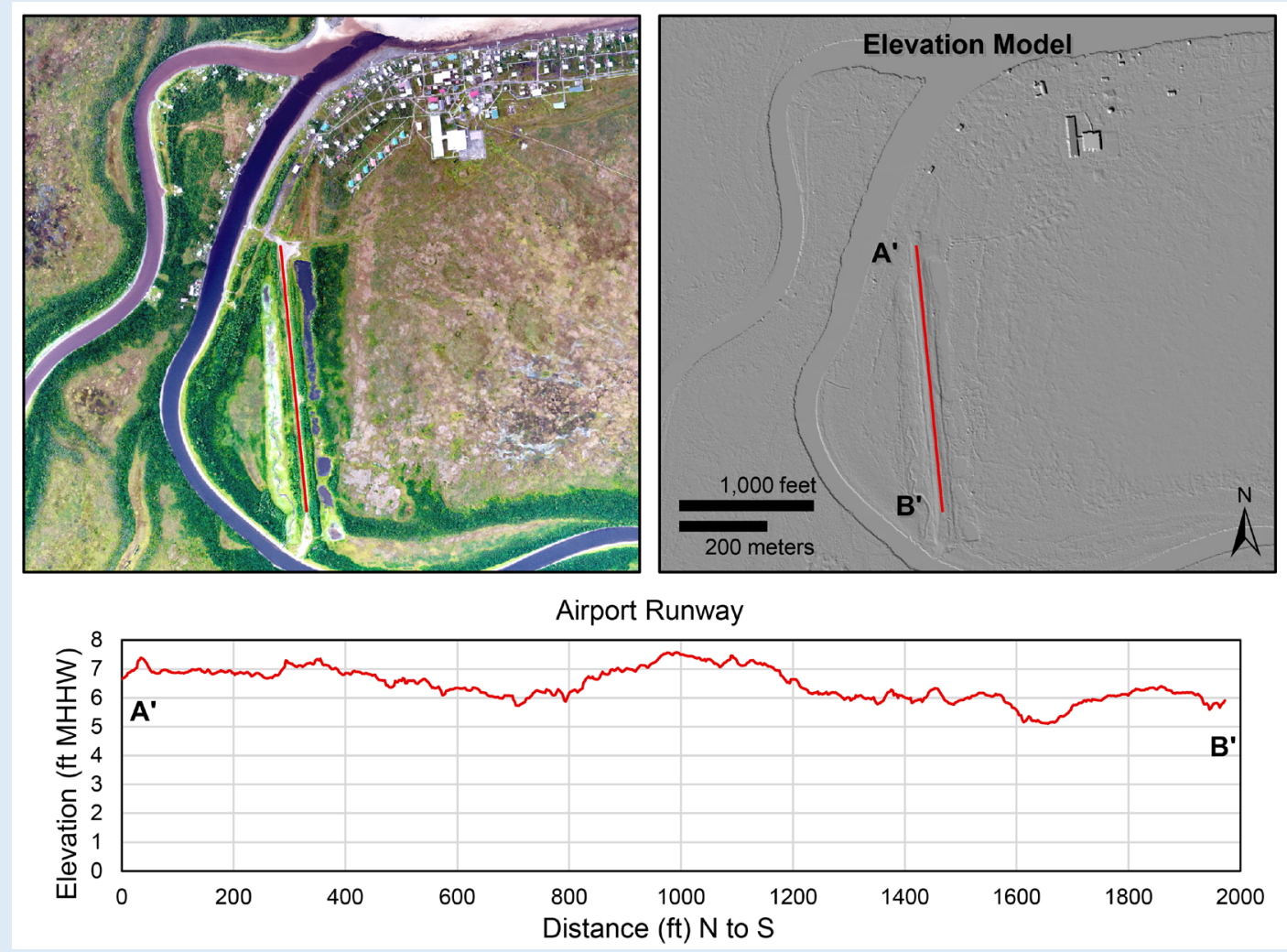

Figure 3. (Top) Image and elevation model (DTM hillshade) of the old airport runway. The elevation profile (red line) drawn on the image is graphed below. The average height is $6.5 \mathrm{ft} \mathrm{MHHW}$ (standard deviation $=0.6 \mathrm{ft}$ ).
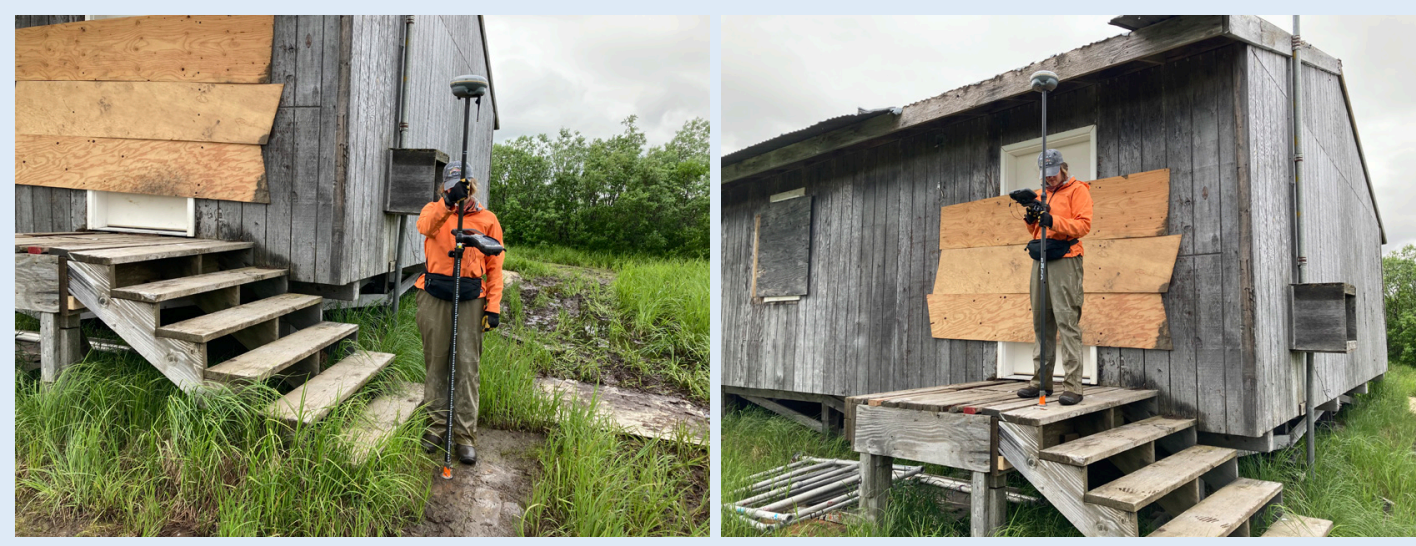

Figure 4. GNSS measurements of teen center ground (left) and porch (right). 
Table 8. Flood parameters used to estimate the 1987 flood. Uncertainty is calculated using the RSS error.

\begin{tabular}{l|l}
\multicolumn{1}{c}{ Feature } & \multicolumn{1}{c}{ Flooding under teen center } \\
\hline Feature represents & $\begin{array}{l}\text { Highest water } \\
\text { Still water }\end{array}$ \\
Water level type & 5.1 \\
\hline Estimate of height (ft MHHW) & 0.1 \\
\hline Uncertainty of ground (ft) & 1.0 \\
Uncertainty of water (ft) & $5.1 \pm 1.0$
\end{tabular}

\section{$1989-$ OCT-07 | $6.3 \pm 1.1 \mathrm{ft} \mathrm{MHHW}$}

\begin{tabular}{cc} 
Reference & Source information relevant to flood height \\
\hline URS (2007) & "50-year flood, 58 people were evacuated and \\
City of Kotlik (2013) & $\$ 195,000$ in damages occurred to 16 homes." \\
City and Village of Kotlik (2019) &
\end{tabular}

The October 1989 storm caused major flooding, damaged 16 homes, and forced 58 people to evacuate to the school (URS, 2007). URS (2007) claims this is a 50-year flood. There are no water level recordings to verify this claim, but it indicates this may be the second-highest flood observed in Kotlik at the time (in many neighboring communities, the November 1974 storm is cited as a 100 -year flood event because it is the highest in memory). The population doubled from 1970 to 1990 (City and Village of Kotlik, 2019), which may explain why this event was not a record but flooded more homes than previous events.

The 1989 flood was likely similar to 1964 (6 homes flooded) but not as high as 1992 (23 homes flooded). This places the flood between $6.2 \pm 0.5$ and $6.5 \pm 1.0 \mathrm{ft} \mathrm{MHHW}$. Using the average and RSS error of uncertainties, we estimate the October 1989 flood reached $6.3 \pm 1.1 \mathrm{ft}$ MHHW.

\section{2-AUG-18 | $6.5 \pm 1.0 \mathrm{ft}$ MHHW}

\section{Reference}

URS (2007)

City of Kotlik (2013)

City and Village of Kotlik (2019)

\section{Source information relevant to flood height}

"The level of water was 2 feet above the average first floor of the affected homes, 108 people were evacuated, and 23 homes suffered damages totaling nearly \$1.9 million."

The August 1992 storm caused major flooding, damaged 23 homes, and forced 108 people to evacuate to the school (URS, 2007). The impacts were similar but more severe than October 1989. The lowest homes at the time were likely around the first-floor elevation of the home identified for the November 1975 flood, $5.0 \pm 0.1 \mathrm{ft}$ MHHW. As of 2021, water reaching $6.0 \mathrm{ft}$ would flood 
19 residences, and water reaching $7.0 \mathrm{ft}$ would flood 40 residences (fig. B1). The population has increased by approximately 50 percent since 1990 (City and Village of Kotlik, 2019), so a flood reaching similar height today may impact more homes. Given these observations, we estimate water reached $1.5 \pm 1.0 \mathrm{ft}$ above the 1975 home first floor. The August $1992 \mathrm{flood}$ estimate is $6.5 \pm 1.0 \mathrm{ft}$ MHHW (table 9).

Table 9. Flood parameters used to estimate the 1992 flood. Uncertainty is calculated using the RSS error.

\begin{tabular}{l|l}
\multicolumn{1}{c}{ Feature } & \multicolumn{1}{c}{ Flooding of residence } \\
\hline Feature represents & $\begin{array}{l}\text { Highest water } \\
\text { Still water }\end{array}$ \\
Water level type & 6.5 \\
\hline Estimate of height (ft MHHW) & 0.1 \\
\hline Uncertainty of residence (ft) & 1.0 \\
Uncertainty of water (ft) & $6.5 \pm 1.0$
\end{tabular}

\section{0-FEB-04 | No water level estimate}

\section{Reference}

City of Kotlik (2013)

\section{Source information relevant to flood height}

None

City of Kotlik (2013) cites this event as possibly affecting Kotlik due a state disaster declaration reaching the Bethel area. However, there is no account of flood impacts in Kotlik or nearby communities, so a flood height cannot be estimated.

\section{2-OCT-08 | No water level estimate}

\section{Reference}

NOAA (2002)

USACE (2008)

\section{Source information relevant to flood height}

None

In 2002, erosion occurred that may have been caused by flooding (USACE, 2008). This was likely the from October 8, 2002 storm that caused flood and erosion impacts in Shishmaref, Kivalina, and Kotzebue (NOAA, 2002). No further information was found so an estimate could not be made. 


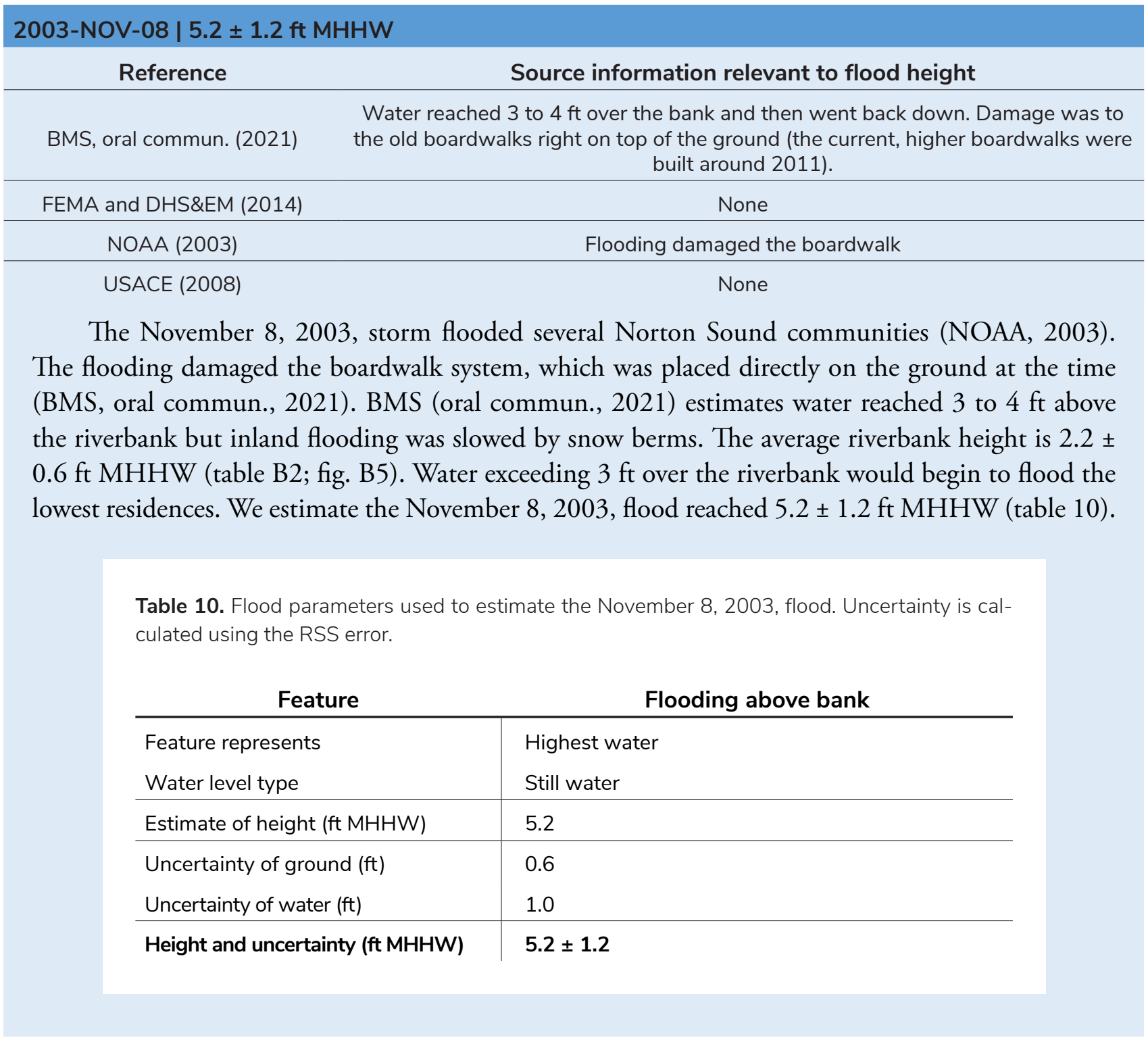

\section{3-NOV-26 | $2.2 \pm 1.0 \mathrm{ft} \mathrm{MHHW}$}

Reference

BMS, oral commun. (2021)

\section{Source information relevant to flood height}

The first concrete blocks were placed in the late 70 s and early 80 s. Then sandbags were placed. This likely damaged the sandbags.

FEMA and DHS\&EM (2014)

NOAA (2003)

USACE (2008)

None

Flooding damaged the bank erosion project (completed in October)

None

The November 26, 2003, storm was the second to flood Norton Sound communities that month (NOAA, 2003). In Kotlik, the only damage cited was to the erosion protection sandbags, suggesting it was lower than the previous flood (NOAA, 2003; BMS, oral commun., 2021). The sandbags were installed in October 2003. Flooding to the riverbank is enough to cover the sandbags. The damage may have been due to ice. Given no overland flood impacts are stated, we estimate water reached within $1 \mathrm{ft}$ of bankfull stage. We estimate the November 26, 2003, flood reached $2.2 \pm 1.0 \mathrm{ft}$ MHHW. 


\section{4-OCT-18 | $5.7 \pm 0.5 \mathrm{ft}$ MHHW}

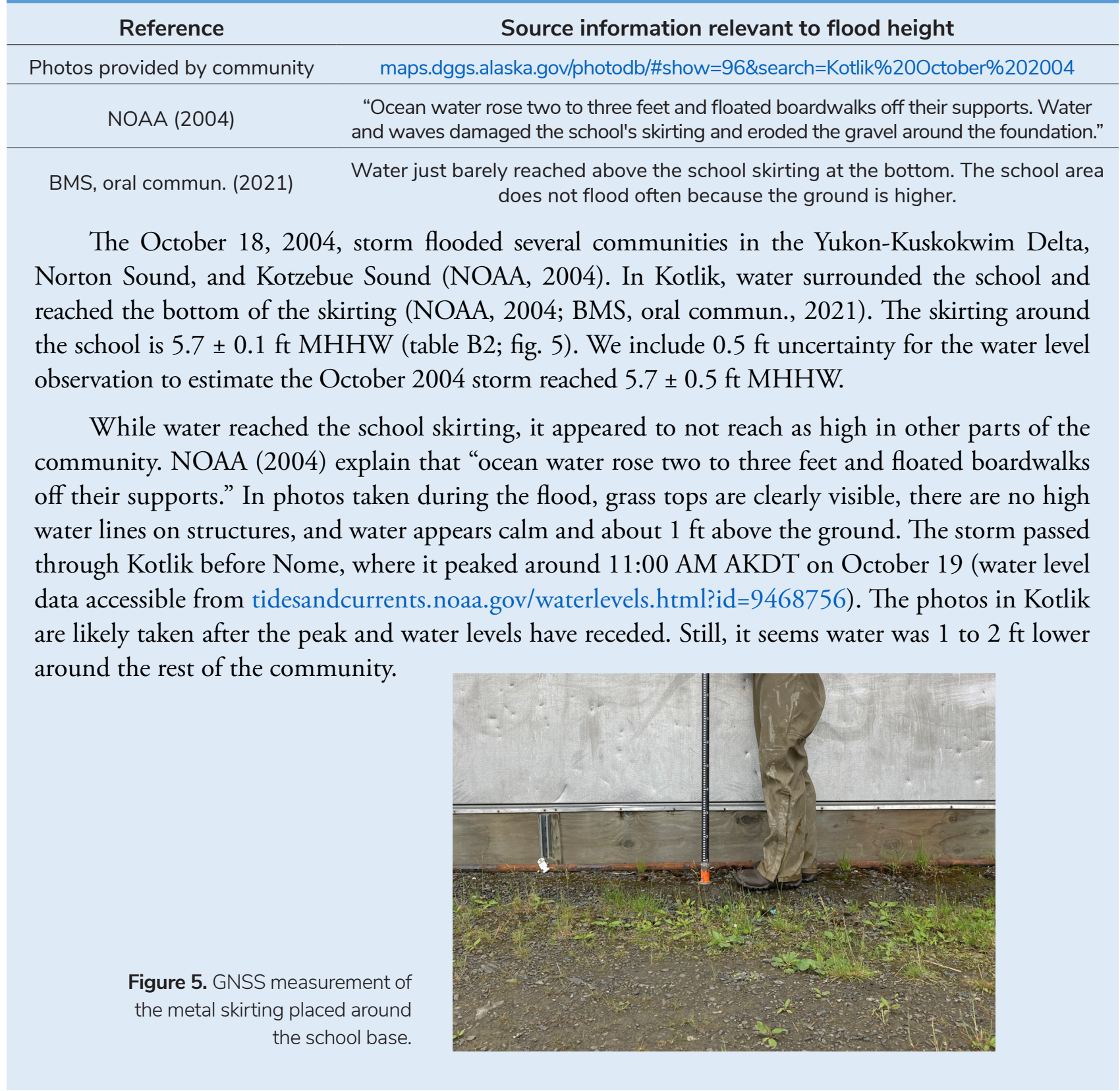

\section{5-JAN | $3.2 \pm 0.8 \mathrm{ft} \mathrm{MHHW}$}

\section{Reference}

City of Kotlik (2013)

City and Village of Kotlik (2019) URS (2007)

USACE (2008)

\section{Source information relevant to flood height}

Flooding with no apparent cause. "Water remained in low-lying areas for more than six hours."

None

In January 2005, low-lying areas were flooded. It was not storm-induced flooding, and there is no evidence found to describe the cause of flooding (URS, 2007). In winter, sloughs can fill up with water that releases on top of the ice causing flooding (BMS, oral commun., 2021). We estimate the flood reached $1.0 \pm 0.5 \mathrm{ft}$ above the riverbank. The January 2005 flood reached $3.2 \pm 0.6 \mathrm{ft} \mathrm{MHHW}$. 


\section{6-OCT-08 | No water level estimate}

\section{Reference}

Source information relevant to flood height

City of Kotlik (2013)

NOAA (2006)

None

The October 2006 storm caused widespread flooding in Bristol Bay and the Kuskokwim Delta, triggering a federal disaster declaration (City of Kotlik, 2013; NOAA, 2006). Either flooding did not reach Kotlik or no impacts were described, so an estimate cannot be made.

\section{9-MAY-25 | $3.0 \pm 0.5 \mathrm{ft}$ MHHW}

\section{Reference}

City and Village of Kotlik (2019)

FEMA and DHS\&EM (2014)

NOAA (2009)

\section{Source information relevant to flood height}

None

Water over road to airport but still passable, considered minor flood

The May 2009 ice jam flood caused minor flooding in Kotlik (NOAA, 2009). The roads near the new airport were covered with water but were passable, and no homes were flooded. The average road height in the low section between the boardwalk and the airport averages $2.0 \pm 0.1 \mathrm{ft}$ MHHW (fig. B4). Water was likely $1.0 \pm 0.5 \mathrm{ft}$ above the low section of road in order to be covered but passable with a four-wheeler. We estimate the May 2009 flood reached $3.0 \pm 0.5 \mathrm{ft}$ MHHW (table 11).

Table 11. Flood parameters used to estimate the May 25, 2009, flood. Uncertainty is calculated using the RSS error.

\begin{tabular}{l|l}
\multicolumn{1}{c}{ Feature } & \multicolumn{1}{c}{ Flooding of road } \\
\hline Feature represents & $\begin{array}{l}\text { Highest water } \\
\text { Still water }\end{array}$ \\
Water level type & 3.0 \\
\hline Estimate of height (ft MHHW) & 0.1 \\
\hline Uncertainty of ground (ft) & 0.5 \\
Uncertainty of water (ft) & $3.0 \pm 0.5$
\end{tabular}




\section{1-NOV-09 | $3.6 \pm 0.7 \mathrm{ft}$ MHHW}

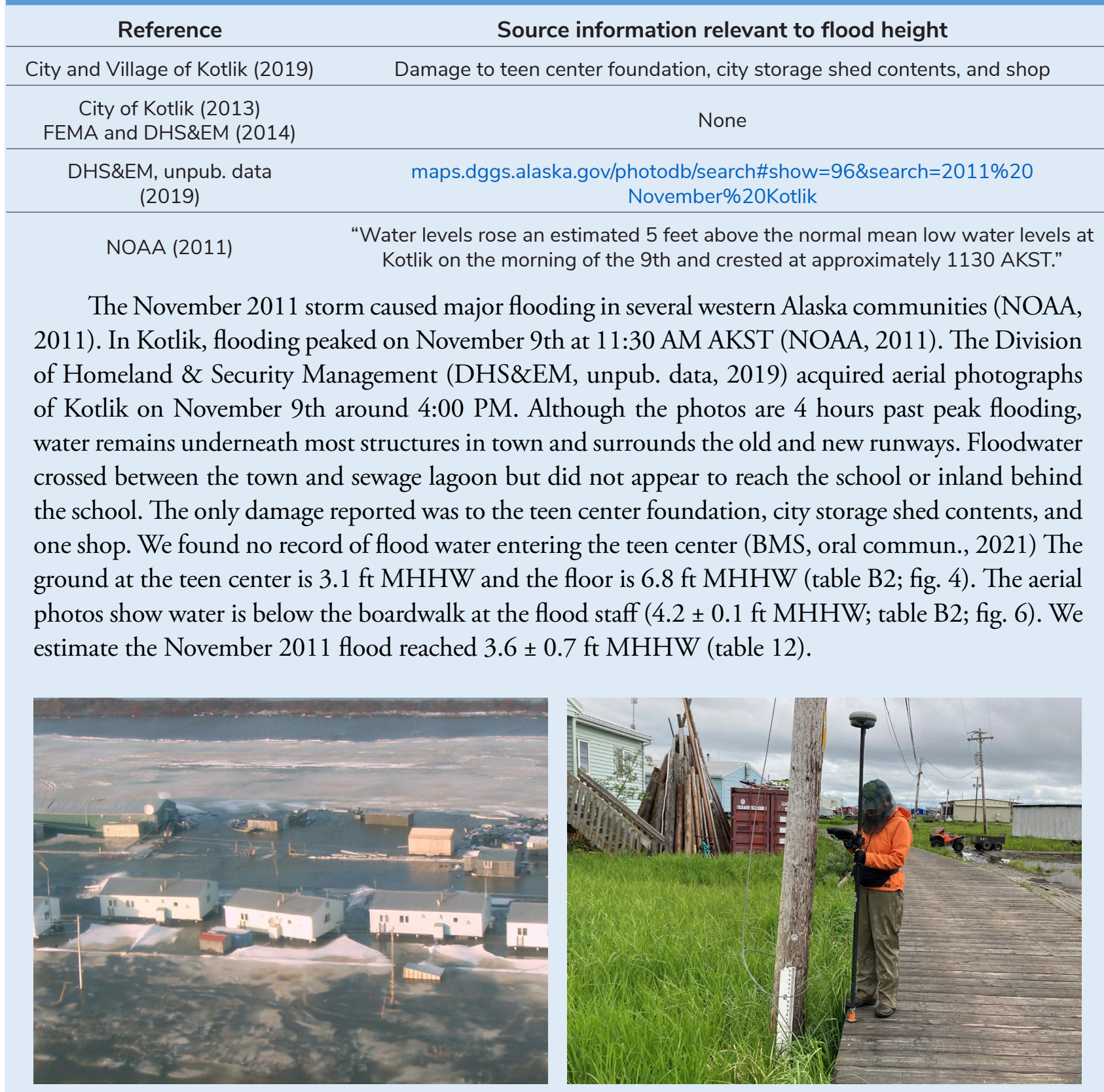

Figure 6. (Left) Photo from plane taken 4.5 hours after peak flooding in Kotlik. Water is below the boardwalk by the telephone pole where the flood staff is installed. (Right) GNNS measurement of boardwalk by the flood staff. 
Table 12. Flood parameters used to estimate the November 9, 2011, flood. Uncertainty is calculated using the upper-lower bounds method.

\begin{tabular}{l|ll}
\multicolumn{1}{c}{ Feature } & Teen center ground & \multicolumn{1}{c}{ Boardwalk } \\
\hline Feature represents & Lowest water & Highest water \\
Water level type & Still water & Still water \\
\hline Estimate of height (ft MHHW) & 3.1 & 4.2 \\
\hline Estimate error (ft) & 0.1 & 0.1 \\
\hline Lower bound (ft MHHW) & 2.9 & 4.1 \\
Upper bound (ft MHHW) & 3.2 & 4.3 \\
\hline Mean and uncertainty (ft MHHW) & & $\mathbf{3 . 6 \pm 0 . 7}$
\end{tabular}

\section{3-NOV-06 | $6.4 \pm 1.1 \mathrm{ft}$ MHHW}

Reference

City and Village of Kotlik (2019)

D'oro (2013)

FEMA and DHS\&EM (2014)

Indigenous Environmental Network (2013)

\section{Source information relevant to flood height}

Damages to Kotlik barge dock. Destroyed honey pot basin. Destroyed community water and sewage system utilidor. Destroyed dump burners, tents and fences. Residents did not have access to clean drinking water or sewage disposal until damage was fixed.

Damage to water and sewer distribution system. Principal's house had chest high rushing water underneath. Caused major septic issues. Homes were damaged or moved.

Main boardwalk had 1-2 ft water on it, not usable during peak water levels. Half the community evacuated to school. Water reached 41 inches below bottom of school subfloor. Highest flood younger people had seen, and highest that many older people remember. Newer buildings and homes were above the water level during the storm and not flooded. A few older buildings did have water above the first floor elevation. Sewer line was damaged.

Damage to sewage and water utilidor. Boardwalk was washed away. Cut off access to running water. More than 100 people evacuated to local shelter. Damage to fueling station caused diesel spill. Sewage water in the streets. School had no heat or running water. People lost their homes. Water plant was damaged. Resident's home flooded to ten inches when they got rescued (the house later burned down). That resident said the damage was worst seen in memory (since 1969).

NOAA (2013)

Surge up to $5 \mathrm{ft}$ in Kuskokwim Delta

The November 2013 storm caused widespread flooding in western Alaska (NOAA, 2013). This was the most damaging flood in Kotlik's history. Floodwater and floating sea and river ice damaged the water and sewer utility corridor that was installed in 2001 (Kotlik CEDS Committee, 2004; FEMA and DHS\&EM, 2014). This removed access to clean water for much of the community and contaminated the flood waters. Water entered at least one home (which later burned down) and more than 100 people evacuated to the school, some requiring rescue (Indigenous Environmental Network, 2013). The diesel fuel station sustained damage, and the school, operating as the evacuation center, did not have heat or water (Indigenous Environmental Network, 2013). 
The main boardwalk had $1.5 \pm 0.5 \mathrm{ft}$ of water during peak flooding (FEMA and DHS\&EM, 2014). The boardwalk averages $5.0 \pm 1.4 \mathrm{ft} \mathrm{MHHW}$ (fig. 7), so the water level is $6.5 \pm 1.5 \mathrm{ft} \mathrm{MHHW}$ (using the RSS error of uncertainties). BMS (oral commun., 2021) identified one structure where water reached $1.2 \pm 0.3 \mathrm{ft}$ inside. The porch height is $5.2 \pm 0.1 \mathrm{ft} \mathrm{MHHW}$ and approximately equal to the inner floor height (table B2; fig. 8). The water height estimate is $6.4 \pm 0.3 \mathrm{ft} \mathrm{MHHW}$. These heights agree and are consistent with accounts, so we use the average and root-mean-square error of uncertainties to estimate the November 2013 flood reached $6.4 \pm 1.1 \mathrm{ft}$ MHHW.
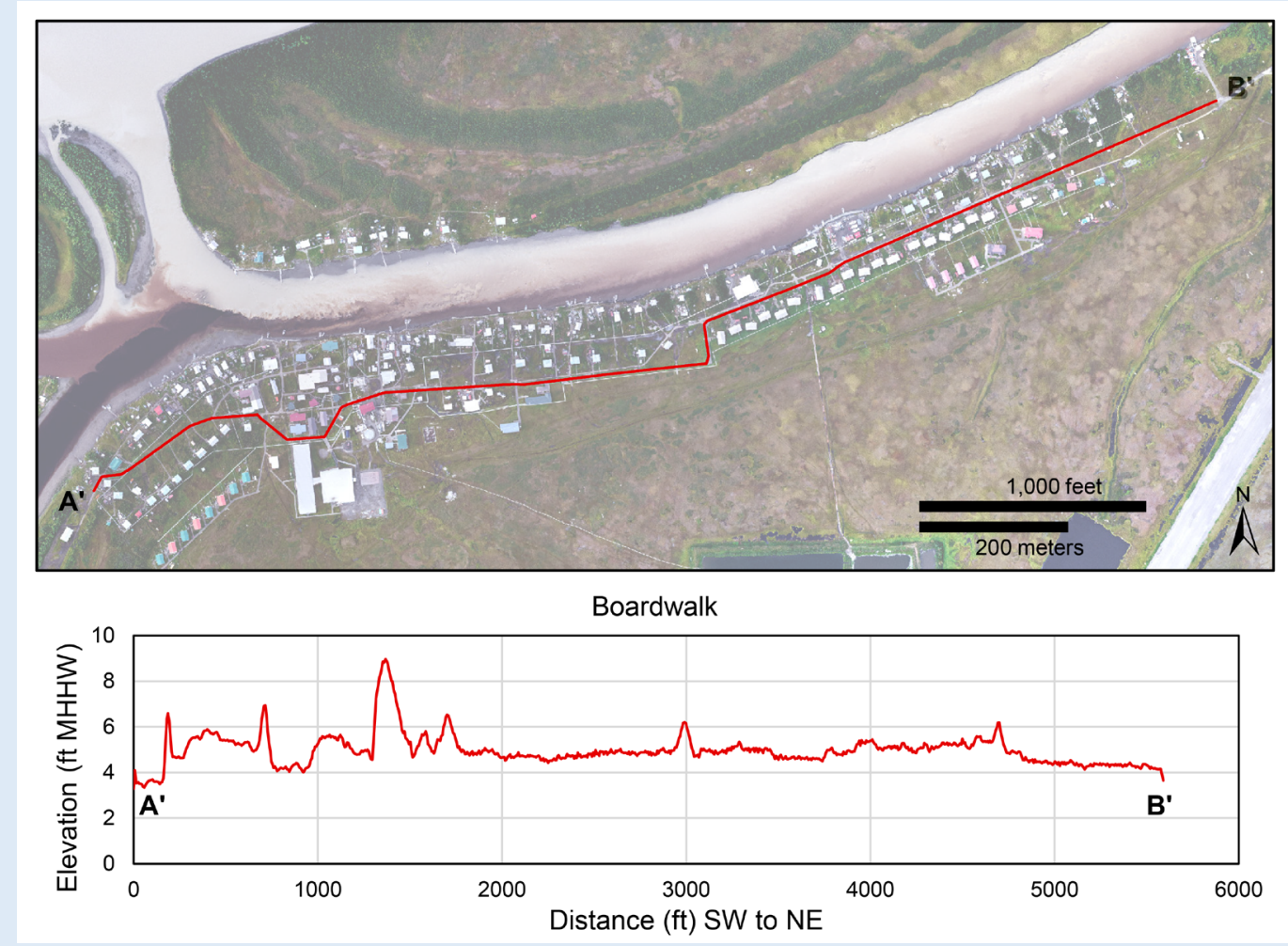

Figure 7. Elevation of the main, elevated boardwalk through Kotlik. Elevation extracted from the 2021 DSM.

By our estimates, the 2013 flood was the third highest in Kotlik's history, and a total of five floods have reached similar or higher levels since 1964. The 2013 flood caused the most damage because there is more infrastructure in Kotlik than when the previous record floods occurred.

Figure 8. The November 2013 flood exceeded this porch step.

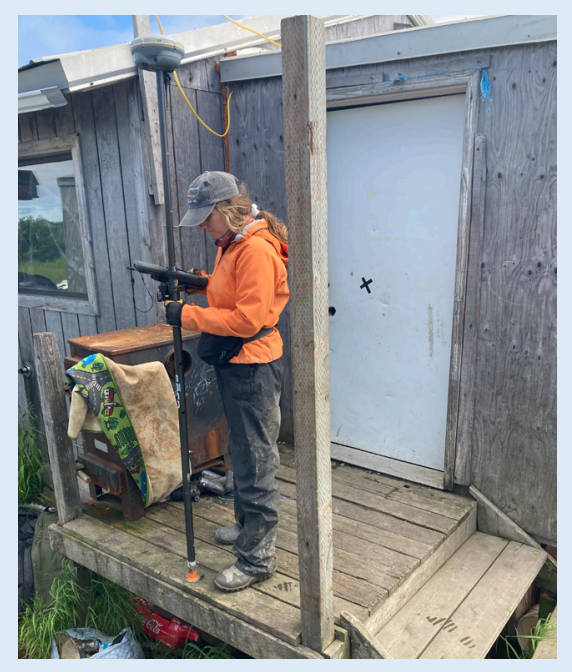




\section{7-JAN-01 | $2.8 \pm 0.7 \mathrm{ft}$ MHHW}

Reference

NOAA (2017)
Source information relevant to flood height

"Coastal flooding in Kotlik"

The January 2017 storm caused 5 to 9 feet of surge in Norton Sound, pushing sea ice on shore and causing minor flood damage in several villages including Kotlik (NOAA, 2017). No further information was found describing impacts, so we estimate the storm reached between minor and moderate flooding, $2.8 \pm 0.7 \mathrm{ft}$ MHHW.

\section{$2017-$ OCT-13 | $2.9 \pm 0.5 \mathrm{ft}$ MHHW}

Reference

Source information relevant to flood height

Harold Okitkun, written commun. (2017)

maps.dggs.alaska.gov/photodb/search\#show=96\&search=2017\%200ct\%20Kotlik

The October 2017 storm caused flooding in Norton Sound and Kotlik. By this time, DGGS installed a flood staff tied to NAVD88 (see Other Flood Information section). Harold Okitkun (written commun., 2017) observed peak flooding from around 3:00 AM on October 13, reaching $0.3 \mathrm{ft}$ on the staff. This is $2.9 \pm 0.1 \mathrm{ft}$ MHHW. Given the measurement is from a single observation, we increase uncertainty to $0.5 \mathrm{ft}$ to account for possible variations in flood level throughout the community. We estimate the October 2017 flood reached $2.9 \pm 0.5 \mathrm{ft}$ MHHW.

\section{7-NOV-12 | $5.3 \pm 0.5 \mathrm{ft}$ MHHW}

Reference

Source information relevant to flood height

Harold Okitkun, written commun. (2017)

maps.dggs.alaska.gov/photodb/search\#show=96\&search=2017\%20Nov\%20kotlik

On November 11, two homes along the riverbank, to the right of the Old Catholic AIJ (2017a) Church, had floodwaters surrounding their homes. There was no reported damage. On November 12, flooding occurred after the tide shifted and came up from the south. Between midnight and $4 \mathrm{am}$, the homes on the island side of Kotlik and homes on the mainland/downtown side of Kotlik were flooded.

The November 12, 2017, storm caused flooding in Norton Sound and Bering Strait communities (AIJ, 2017a). In Kotlik, flooding peaked between midnight and 4:00 AM on November 12 (AIJ, 2017a). Harold Okitkun (written commun., 2017) observed water levels at $0.0 \mathrm{ft}$ on the flood staff $(2.6 \pm 0.1 \mathrm{ft} \mathrm{MHHW})$ several hours after peak flooding. Some homes on the island side (north) and mainland side (south) were flooded, but the exact number or location is not reported (AIJ, 2017a). The lowest residences on the island side are $5.3 \mathrm{ft} \mathrm{MHHW}$. The lowest residence on the mainland side is $4.1 \mathrm{ft}$ MHHW. Given no reports of major damages, evacuations, or loss of structures, we assume water reached within $0.5 \mathrm{ft}$ of the first floor of the lowest island residences. One quarter to one half of these homes were flooded at most. We estimate the November 12, 2017, flood reached $5.3 \pm 0.5$ ft MHHW (table 13). 
Table 13. Flood parameters used to estimate the November 12, 2017, flood. Uncertainty is calculated using the RSS error.

\begin{tabular}{l|l}
\multicolumn{1}{c}{ Feature } & \multicolumn{1}{c}{ Flooding of lowest island residences } \\
\hline Feature represents & $\begin{array}{l}\text { Highest water } \\
\text { Still water }\end{array}$ \\
Water level type & 5.3 \\
\hline Estimate of height (ft MHHW) & 0.1 \\
\hline Uncertainty of ground (ft) & 0.5 \\
Uncertainty of water (ft) & $5.3 \pm 0.5$
\end{tabular}

\section{7-NOV-21 | $4.3 \pm 0.5 \mathrm{ft}$ MHHW}

\section{Reference}

\section{Source information relevant to flood height}

Harold Okitkun, written commun. (2017)

AIJ (2017a)

maps.dggs.alaska.gov/photodb/search\#show=96\&search=2017\%20Nov\%20kotlik

Water exceeded the bank but did not reach the flood staff. Water under new building by tank farm.

The November 21, 2017, storm caused flooding from Bristol Bay to Norton Sound (AIJ, 2017a). In Kotlik, water exceeded the riverbank $(2.2 \pm 0.6 \mathrm{ft} \mathrm{MHHW})$ at 8:30 PM and peaked around 11:30 PM (AIJ, 2017a). Water, blocked by snowbanks, did not go inland far enough to reach the flood staff $(2.6 \pm 0.1 \mathrm{ft} \mathrm{MHHW})$. Water surrounded the new building near the tank farm (AIJ, 2017a). The ground height at this building is $3.7 \pm 0.1 \mathrm{ft} \mathrm{MHHW}$ (table B2; fig. 9). Water appears to be just above the $4 \mathrm{x} 4$ block supports resting on the ground underneath the vertical supports (AIJ, 2017a). We assume this is near the peak water level and estimate water is $0.6 \pm 0.5 \mathrm{ft}$ above the ground. We estimate the November 21, 2017, flood reached $4.3 \pm 0.5 \mathrm{ft}$ MHHW (table 14).

Figure 9. GNSS measurement of ground at new building by tank farm where water was pictured underneath.

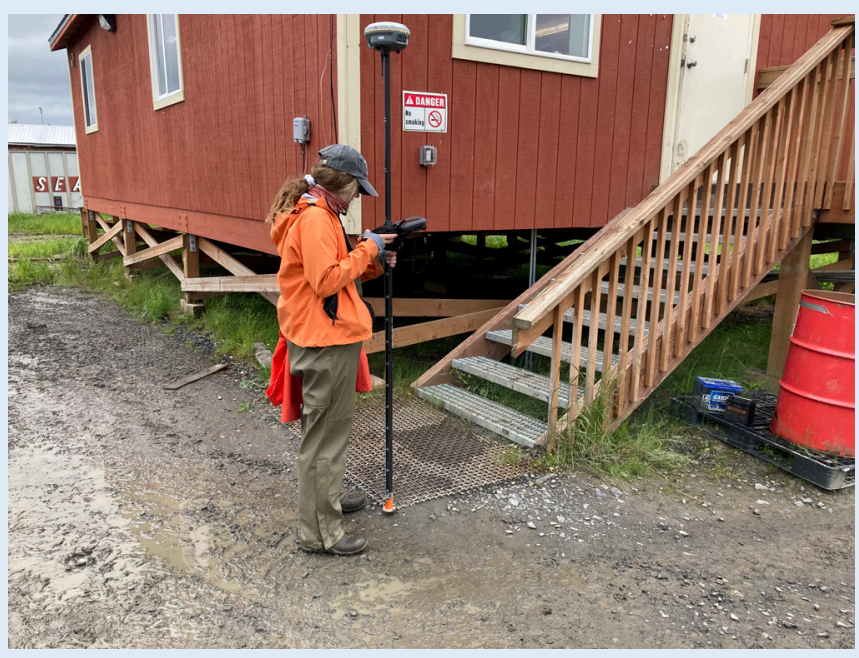


Table 14. Flood parameters used to estimate the November 21, 2017, flood. Uncertainty is calculated using the RSS error.

\begin{tabular}{l|l}
\multicolumn{1}{c}{ Feature } & \multicolumn{1}{c}{ Water around building } \\
\hline Feature represents & $\begin{array}{l}\text { Highest water } \\
\text { Still water }\end{array}$ \\
Water level type & 4.3 \\
\hline Estimate of height (ft MHHW) & 0.1 \\
\hline Uncertainty of ground (ft) & 0.5 \\
Uncertainty of water (ft) & $\mathbf{4 . 3 \pm 0 . 5}$
\end{tabular}

\section{7-DEC-18 | $2.5 \pm 0.6 \mathrm{ft}$ MHHW}

\section{Reference}

AIJ (2017b)

\section{Source information relevant to flood height}

“...minor flooding occurred in low-lying areas behind the AC Store up to the boardwalk. Ice came up level with the bank during the evening"

The December 2017 storm caused flooding in the Yukon-Kuskokwim Delta (AIJ, 2017b). In Kotlik, water exceeded the riverbank $(2.2 \pm 0.6 \mathrm{ft} \mathrm{MHHW})$ and reached the lower boardwalks by the Alaska Commercial store. The top of the boardwalk and base of the ramp at the store is $2.8 \pm 0.1 \mathrm{ft}$ MHHW (table B2; fig. 10). We estimate that the December 2017 flood reached halfway between the riverbank and the ramp, $2.5 \pm 0.6 \mathrm{ft}$ MHHW.

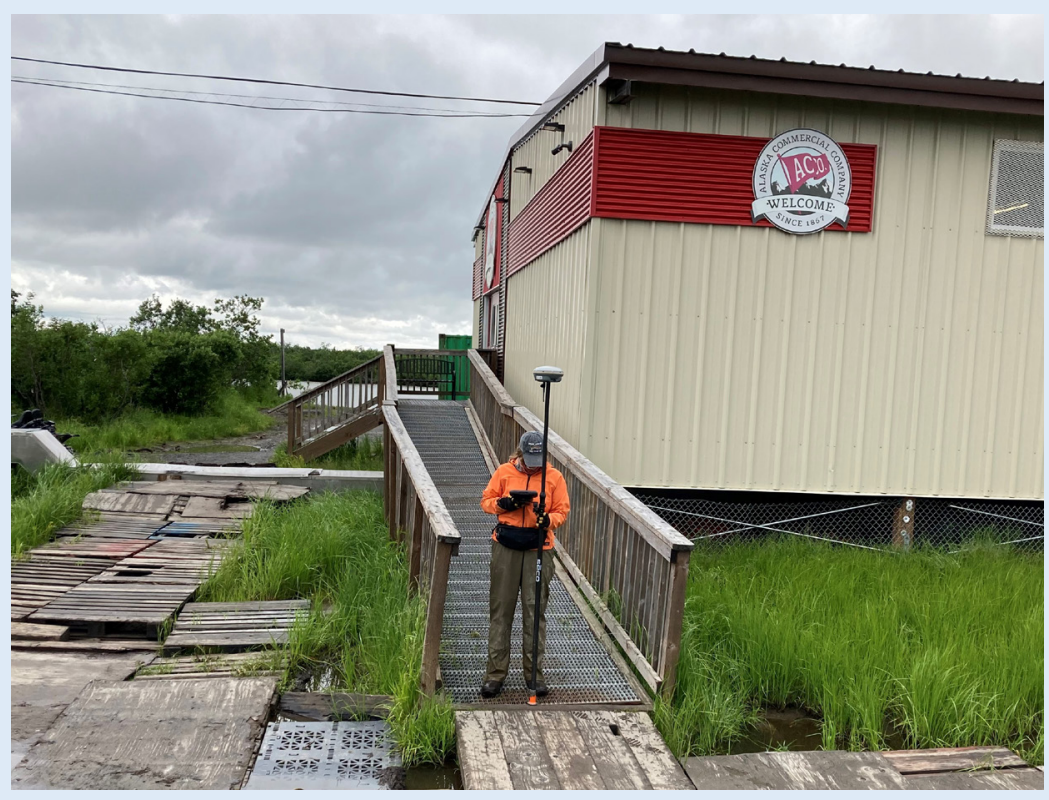

Figure 10. GNSS measurement of the base of the ramp at the Alaska Commercial store. 


\section{8-NOV-09 | $2.9 \pm 0.5 \mathrm{ft} \mathrm{MHHW}$}

Reference

\begin{tabular}{cc}
$\begin{array}{c}\text { Harold Okitkun, written commun. } \\
\text { (2018) }\end{array}$ & $\begin{array}{c}\text { maps.dggs.alaska.gov/photodb/search\#show=96\&search=Kotlik\%202018\%20 } \\
\text { November }\end{array}$ \\
\hline AIJ (2018) & Minor flooding, some water over the bank, near the AC store, and near the flood staff
\end{tabular}

The November 2018 storm caused minor elevated water levels in Norton Sound (AIJ, 2018). Harold Okitkun (written commun., 2018) measured $0.26 \mathrm{ft}$ water level on the flood staff $(2.9 \pm 0.1$ $\mathrm{ft} \mathrm{MHHW}$ ). Water reached the base of the ramp at the Alaska Commercial store, which is $2.8 \pm 0.1$ $\mathrm{ft}$ MHHW (table B2). We use the highest observed flood level and increase uncertainty to $0.5 \mathrm{ft}$ to account for possible variations in flood level throughout the community. We estimate the November 2018 flood reached $2.9 \pm 0.5 \mathrm{ft}$ MHHW.

\section{9-FEB-12 | $5.5 \pm 0.5 \mathrm{ft}$ MHHW}

\section{Reference}

AIJ (2019a)

City and Village of Kotlik (2019)

\section{Source information relevant to flood height}

Water rose 4 to 8 feet. At least six homes had damage to foundation and insulation. maps.dggs.alaska.gov/photodb/search\#show=96\&search=Kotlik\%20 2019\%20February\%2012

The February 12, 2019, storm caused widespread flooding of Yukon-Kuskokwim Delta and Norton Sound communities (AIJ, 2019a). In Kotlik, water floated and fissured river ice and eventually flooded over the riverbank, peaking between midnight and 7:00 AM on the 12th. Water reached the first floor of at least six homes (AIJ, 2019a). The lowest six homes have a first-floor height of 5.3 $\pm 0.1 \mathrm{ft}$ MHHW or less (fig. B1). We identified three residences where water reached at least the first floor, with the highest being $5.5 \pm 0.1 \mathrm{ft}$ MHHW. We use the highest observed flood level and increase uncertainty to $0.5 \mathrm{ft}$ to account for variability in flood level across the community. We estimate the February 2019 flood reached $5.5 \pm 0.5 \mathrm{ft}$ MHHW.

\section{9-FEB-28 | $2.7 \pm 0.8 \mathrm{ft}$ MHHW}

Reference

Harold Okitkun, written commun. (2019)

\section{Source information relevant to flood height}

maps.dggs.alaska.gov/photodb/search\#show=96\&search=Kotlik\%202019\%20 February\%2028

The February 28, 2019, storm caused less severe flooding in Kotlik than the previous event, reaching just above bankfull stage (Harold Okitkun, written commun., 2019). We estimate that water reached $0.5 \pm 0.5$ above the riverbank $(2.2 \pm 0.6 \mathrm{ft}$ MHHW). Using the RSS error of the riverbank and water level uncertainties, we estimate the February 28, 2019, flood reached $2.7 \pm 0.8 \mathrm{ft}$ MHHW. 


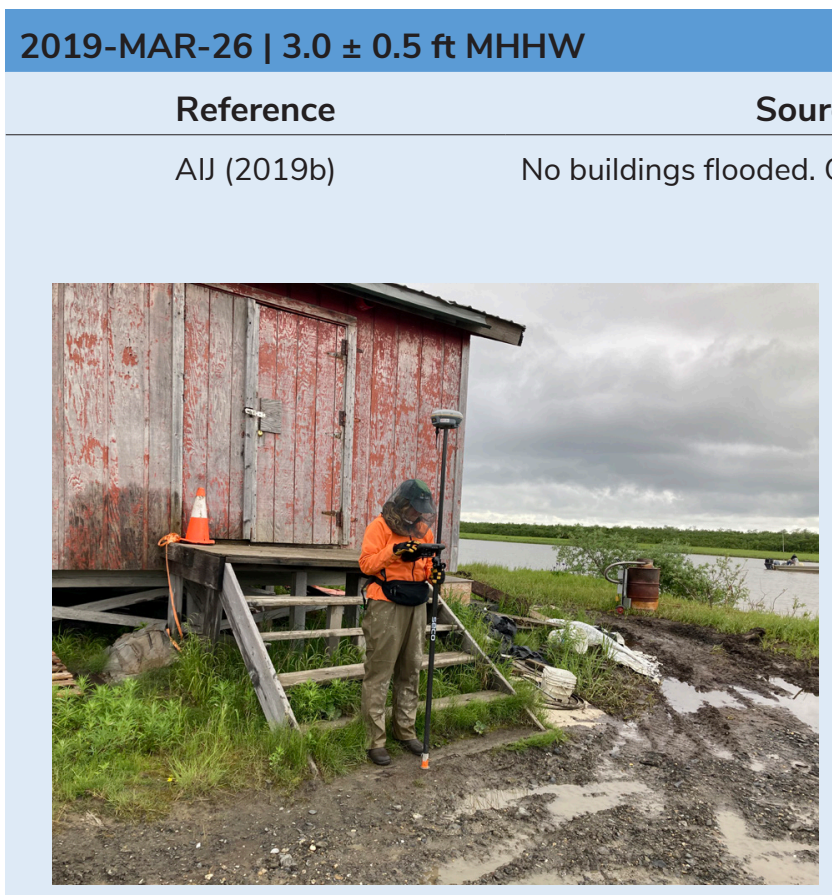

Figure 11. GNSS measurement of step where March 2019 flood reached.
The March 2019 storm caused minor flooding in Kotlik, reaching similar heights as on February 28, 2019 (AIJ, 2019b). At the Nome tide gage, the storm surge reached a similar height as the two February 2019 storms. BMS (oral commun., 2021) identified a porch step near the tank farm where water peaked at $3.0 \pm 0.1 \mathrm{ft}$ MHHW (table B2; fig. 11). This height is consistent with AIJ (2019b) accounts that no buildings were flooded, and the coastal flood advisory predicted water reaching between 2 and $4 \mathrm{ft}$ above the normal high tide. We increase uncertainty to 0.5 to account for possible variations in flood level throughout the community. We estimate the March 2019 flood reached $3.0 \pm 0.5 \mathrm{ft}$ MHHW.

\section{9-JUL-03 | $3.4 \pm 0.5 \mathrm{ft} \mathrm{MHHW}$}

\section{Reference}

Harold Okitkun, written commun. (2019)

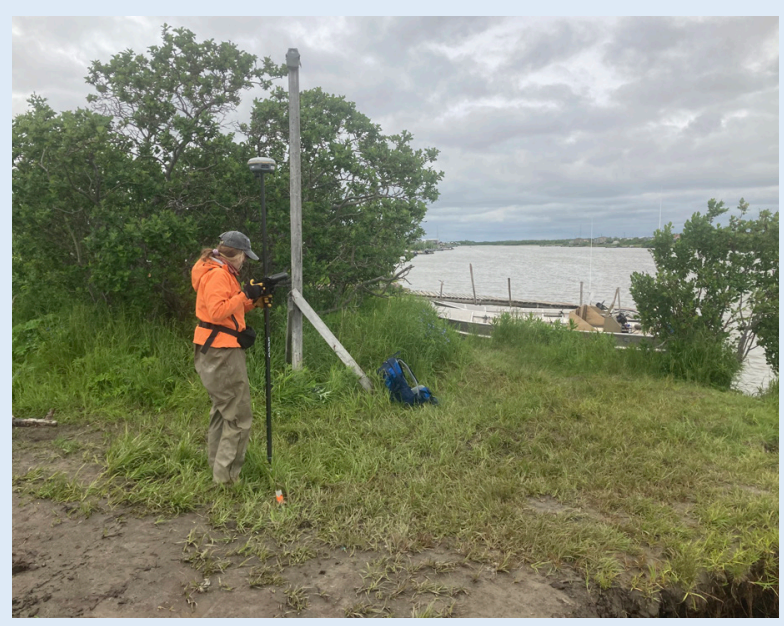

Figure 12. GNSS measurement of flooded ground near erosion camera.

\section{Source information relevant to flood height}

\section{search\#show=96\&search=Kotlik\%202019\%20july}

The July 2019 storm caused minor flooding in Kotlik. Photos taken near peak flooding show water reaching the ramp of the new tank farm building's west ramp where the railing begins. This is $3.3 \pm 0.2 \mathrm{ft}$ MHHW as measured from the 2021 DSM. In a second photo taken near the center of town where DGGS has installed an erosion monitoring camera, we estimate $0.5 \pm 0.3$ $\mathrm{ft}$ of water covers the ground. We measured the ground height with GNSS (table B2; fig. 12) to find a water level estimate of $3.4 \pm 0.3 \mathrm{ft}$ MHHW. We use the average of these calculations (and RSS of uncertainty) to estimate the July 2019 flood reached $3.4 \pm 0.5 \mathrm{ft}$ MHHW. 


\section{9-AUG-03 | $4.7 \pm 0.5 \mathrm{ft}$ MHHW \\ Reference \\ Source information relevant to flood height \\ Harold Okitkun, written commun. (2019) \\ maps.dggs.alaska.gov/photodb/\#show=96\&search=kotlik\%20august\%202019 \\ AlJ (2019c) \\ Flooding over boardwalks, about two and a half feet. Water reached insulation of homes in low lying areas. Damage to boardwalks and low-lying property. \\ The August 2019 storm flooded several communities from the Yukon-Kuskokwim Delta to the Bering Strait (AIJ, 2019c). The peak occurred around 11:40 AM on August 3rd. Harold Okitkun (written commun., 2019) and other residents (AIJ, 2019c) photographed flood impacts, beginning with the bankfull stage at 6:15 AM $(2.2 \pm 0.6 \mathrm{ft}$ MHHW) and the flood staff at 7:35 AM reading 0.26 ft $(2.9 \pm 0.1 \mathrm{ft} \mathrm{MHHW})$. By 8:11 AM, water reached the boardwalk, and by 9:40 AM had overtopped a portion east of the Alaska Commercial store. At 11:40 AM, peak flooding was photographed at a portion of the boardwalk at the turn east of the clinic that measures $4.7 \pm 0.2 \mathrm{ft}$ MHHW (from the 2021 DSM). Other photos published in AIJ (2019c) show floodwater flush with the boardwalk and inundating the lowest sections. The average boardwalk height is $5.0 \pm 1.4 \mathrm{ft} \mathrm{MHHW}$ (fig. 7). We use the peak flood observation to estimate the flood height and increase uncertainty to 0.5 to account for varied flood elevations seen around the boardwalk. We estimate the August 2019 flood reached $4.7 \pm 0.5 \mathrm{ft}$ MHHW.}

\section{9-OCT-04 | $3.3 \pm 0.5 \mathrm{ft}$ MHHW}

Reference

AIJ (2019d)

\section{Source information relevant to flood height}

Flooding took several boats upriver. No flooded homes, damaged boats, or widespread damage of personal property. Some displaced boardwalks.

The October 2019 storm surge elapsed from the 4th to the 6th, and the greatest flooding coincided with the highest tide on the 5th at 10:30 PM (AIJ, 2019d). With advanced warning, the community moved property to higher elevation and reduced potential flood impacts (AIJ, 2019d). Photos of the flood staff throughout the event show the flood peaked at $2: 12 \mathrm{AM}$, reaching $0.58 \mathrm{ft}$ $(3.3 \pm 0.1 \mathrm{ft} \mathrm{MHHW})$. Given the measurement is from a single observation, we increase uncertainty to $0.5 \mathrm{ft}$ to account for possible variations in flood level throughout the community. The October 2019 flood reached $3.3 \pm 0.5 \mathrm{ft}$ MHHW.

\section{0-NOV-11| $4.2 \pm 0.5 \mathrm{ft}$ MHHW}

Source information relevant to flood height
$\begin{gathered}\text { RMS, oral commun. (2021) } \\ \text { Fovey (2020) }\end{gathered}$
The November 2020 storm caused flooding in Bering Strait and Norton Sound communi-
Therdwalk height at flood staff
ties (Hovey, 2020). Water reached the boardwalk height near the flood staff, which is $4.2 \pm 0.1$
$\mathrm{ft}$ MHHW (BMS, oral commun., 2021). Sea ice was not present in Kotlik at the time (Hovey,
2020). We increase uncertainty to 0.5 to account for possible variations in flood level throughout the
community. The November 2020 flood reached $4.2 \pm 0.5 \mathrm{ft}$ MHHW.




\section{OTHER FLOOD INFORMATION}

DGGS installed a flood staff in Kotlik in June 2017. It is on a power pole next to the main boardwalk by the ANTHC yard, east of the Alaska Commercial store (fig. 13; see map sheet Kotlik). The zero mark on the flood staff is $2.6 \pm 0.1 \mathrm{ft}$ MHHW. We can use a photo of the staff in floodwater to estimate the height of floods.

\section{ACKNOWLEDGMENTS}

This work was funded by Bureau of Indian Affairs Tribal Resilience Program through a collaborative project with the Native Village of Bill Moore's Slough. Significant contributions to this work have been made by the tribe, specifically by Harold Okitkun. Harold has been the primary source of photos and descriptions of flooding at Kotlik and correspondence regarding flood events in recent years.

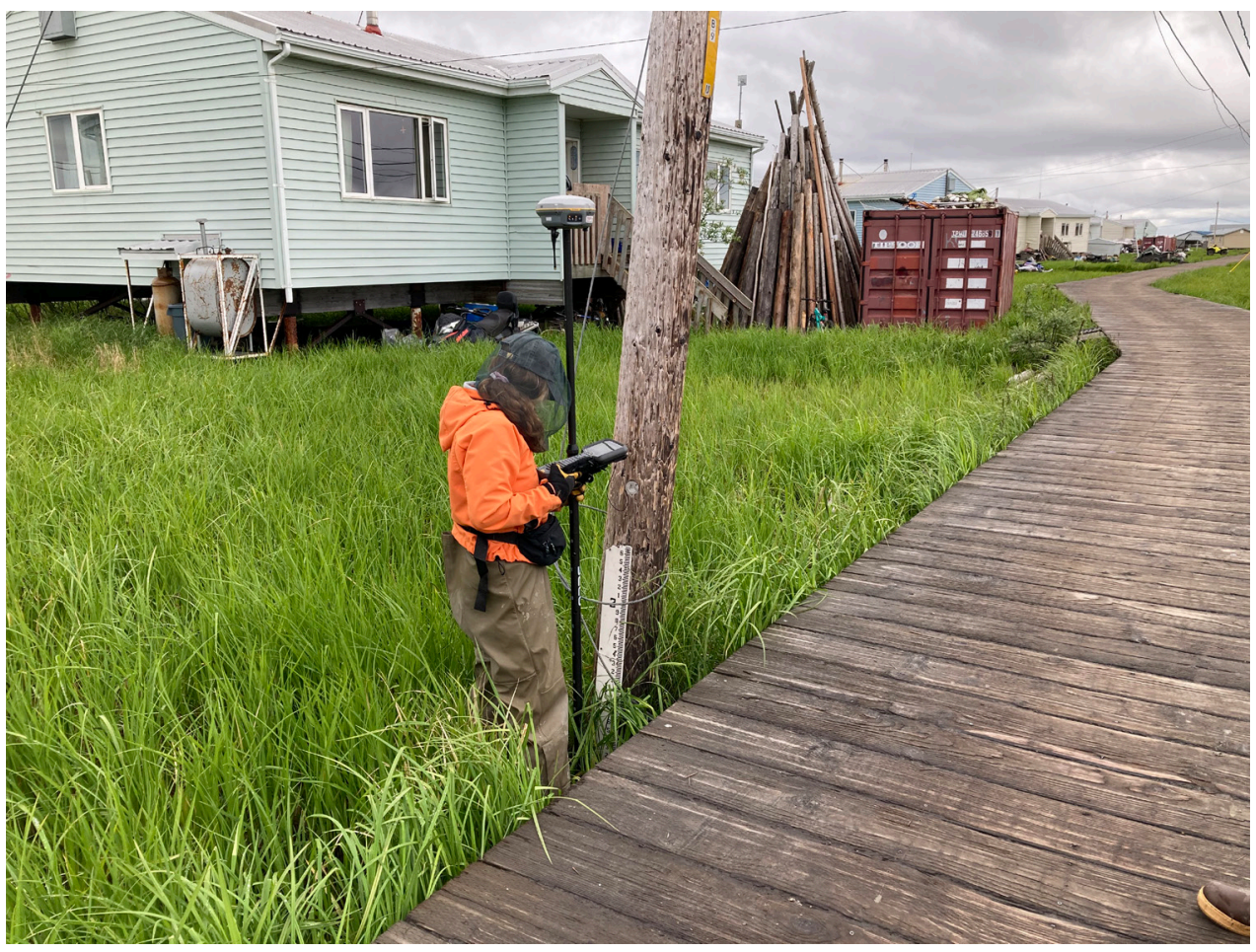

Figure 13. Flood staff installed on power pole in Kotlik. 


\section{REFERENCES}

Alaska Institute for Justice (AIJ), 2017a, November 2017 storm and weather narratives: Alaska Institute for Justice, $32 \mathrm{p}$.

2017b, December 2017 storm and weather narratives: Alaska Institute for Justice, 23 p.

2018, November 2018 storm \& weather narratives: Alaska Institute for Justice, 20 p.

2019a, February 2019 storm \& weather narratives: Alaska Institute for Justice, 22 p.

2019b, March 2019 storm \& weather narratives: Alaska Institute for Justice, 9 p.

2019c, August 2019 storm \& weather narratives: Alaska Institute for Justice, $17 \mathrm{p}$.

2019d, September and October 2019 storm \& weather narratives: Alaska Institute for Justice, 22 p.

Buzard, R.M., Christian, J.E., and Overbeck, J.R., 2021b, Photogrammetry-derived orthoimagery and elevation for Kotlik, Alaska, collected July 10, 2021: Alaska Division of Geological \& Geophysical Surveys Raw Data File 2021-xx, 4 p. http://doi.org/10.14509/xxxxx

Buzard, R.M., Overbeck, J.R., Chriest, Jonathan, Endres, K.L., and Plumb, E.W., 2021a, Coastal flood impact assessments for Alaska communities: Alaska Division of Geological \& Geophysical Surveys Report of Investigation 2021-1, 16 p. https://doi.org/10.14509/30573

City of Kotlik, 2013, Local hazard mitigation plan: City of Kotlik, 105 p.

City of Kotlik and Village of Kotlik, 2019, Multijurisdictional hazard mitigation plan: LeMay Engineering \& Consulting, Inc., 195 p.

D'oro, Rachel, 2013, W. Alaska residents clean up after coastal storm: Alaska Dispatch News [website]: found at https://www.adn.com

Federal Emergency Management Agency and Alaska Department of Homeland Security \& Emergency Management (FEMA and DHS\&EM), 2014 Kotlik trip report, NOAA, 6 p.

Herbst, A.M., and Daanen, R.P., 2020, Highresolution lidar data for Kotlik, western Alaska: Alaska Division of Geological \& Geophysical Surveys Raw Data File 2020-15, 7 p. https://doi. org/10.14509/30561
Hovey, Davis, 2020, Minor to severe erosion across the region caused by strong Bering Sea storm: KNOM [website] found at: https://www.knom. org/

Indigenous Environmental Network, 2013, Heavy storm devastates coastal communities in western Alaska: Indigenous Environmental Network [website]: found at https://www.ienearth.org

Kotlik CEDS Committee, 2004, Kotlik comprehensive economic development strategic plan (CEDS): Kotlik CEDS Committee, 22 p.

Kotlik Tribal Council, 2008, Kotlik community development plan: Kotlik Tribal Council, 99 p.

Kotlik Tribal Council, 2010, Kotlik community development plan: Kotlik Tribal Council, 43 p.

Overbeck, J.R., Hendricks, M.D., and Kinsman, N.E.M., 2016, Photogrammetric digital surface models and orthoimagery for 26 coastal communities of western Alaska: Alaska Division of Geological \& Geophysical Surveys Raw Data File 2016-1, 3 p. https://doi.org/10.14509/29548

National Oceanographic and Atmospheric Administration Center for Operational Oceanographic Products and Services (NOAA CO-OPS), 2021, Datums for 9467861, Kotlik, AK [website]: found at https://tidesandcurrents. noaa.gov/datums.html?id=9467861

NOAA, 1974, Storm data-November 1974: U.S. Department of Commerce, v. 16, no. 11, 7 p. -1987, Storm data-October 1987: U.S. Department of Commerce, v. 29, no. 10, 32 p. 2002, Storm data-October 2002: U.S. Department of Commerce, v. 44, no. 10, 114 p. 2003, Storm data-November 2003: U.S.

Department of Commerce, v. 45, no. 11, 174 p. 2004, Storm data-October 2004: U.S.

Department of Commerce, v. 46, no. 10, 156 p. 2006, Storm data-October 2006: U.S.

Department of Commerce, v. 48, no. 10, 154 p. -2009, Storm data-May 2009: U.S. De-

partment of Commerce, v. 51, no. 5, 570 p.

-2011, Storm data-November 2011: U.S.

Department of Commerce, v. 53, no. 11, 184 p. 2013, Storm data-November 2013: U.S.

Department of Commerce, v. 55, no. 11, 294 p. 2017, Storm data-January 2017: U.S. 
Department of Commerce, v. 59, no. 1, 307 p. U.S. Army Corps of Engineers, 1982, Flood history survey-Kotlik: USACE Alaska District, 6 p. 1987, Flood history survey-Kotlik: USACE Alaska District, 3 p. 2008, Erosion information paper-Kotlik, Alaska: USACE Alaska District, 5 p. 2011, Alaska floodplain management flood hazard data-Kotlik: USACE Civil Works Branch, 1 p.

2012, Kotlik flood plain survey: Flood history survey-Kotlik: USACE, 13 p.

2021, Ice jam database: USACE [website]: found at https://icejam.sec.usace.army.mil/

U.S. Census Bureau, 1880, Statistics of the population of the United States at the tenth census: Washington, D.C., U.S. Government Printing Office, $931 \mathrm{p}$.

URS, 2007, Hazard mitigation plan-City of Kotlik, Alaska: URS, 116 p.

Wise, J.L., Comiskey, A.L., and Becker, R., Jr., 1981, Storm surge climatology and forecasting in Alaska: Anchorage, Alaska, Arctic Environmental Information and Data Center, University of Alaska, 32 p. 


\section{APPENDIX A: FLOOD-RELATED ACCOUNTS}

There are many written reports that contain flood information for Kotlik. Reports may be difficult to find in the future as their online linked location can change. This appendix provides the exact relevant text from each source used in this report to preserve the information. Any added commentary or summary information is enclosed by brackets.

Alaska Institute for Justice (AIJ), 2017a, November 2017 storm and weather narratives: Alaska Institute for Justice, 32 p.

Observed Storm Details: On November 9, south winds were gusting at 30 to $40 \mathrm{mph}$. The tide usually goes out with south winds. High waters and stronger winds occur during west winds. At 9pm on November 10, the wind shifted and the river water levels reached the top of the bank and by 3:30am the high tide peaked. On November 11, southwest winds shifted to northwest winds, which caused elevated sea levels when the high tide peaked.

Observed Storm Impacts: On November 11, two homes along the riverbank, to the right of the Old Catholic Church, had floodwaters surrounding their homes. There was no reported damage. On November 12, flooding occurred after the tide shifted and came up from the south. Between midnight and $4 \mathrm{am}$, the homes on the island side of Kotlik and homes on the mainland/downtown side of Kotlik were flooded. Floodwaters also reached the front of Harold Okitkun's house, where 2 x 4 boards that elevated the boardwalk were washed out from the flood. Harold repaired the boardwalk in front of his house for the second time in two months (Harold Okitkun, Tanya Hunt, and Victor Tonuchuk, AIJ personal communication, November 13, 2017).

[Photos of flooding]

2017b, December 2017 storm and weather narratives: Alaska Institute for Justice, 23 p.

Forecast: On December 18, 2017 the NWS issued a high surf alert in the afternoon and evening of December 18 for the Kuskokwim Bay. Water levels are expected to rise 2 to 4 feet above high tide. Southwesterly winds gusting between 30 and $45 \mathrm{mph}$ and waves are expected to create rough surf along the coast. The surge is expected to increase in Kotlik the evening of December 20 with the high tide occurring overnight. The tide is expected to come a little higher than December 19 and is expected to peak at midnight (Rick Thoman - National Weather Service, AIJ teleconference, December 20, 2017).

Storm Details: Kotlik experienced a winter storm with low visibility from December 18 to December 19 . Southerly winds blowing between 50 to 55 knots led to high waters. The water went back down but returned on December 20 with the high tide.

Storm Impacts: On December 18 and 19, minor flooding occurred in low-lying areas behind the AC Store up to the boardwalk. Ice came up level with the bank during the evening (Harold Okitkun and Victor Tonuchuk, AIJ personal communication December 22, 2017).

2018, November 2018 storm \& weather narratives: Alaska Institute for Justice, 20 p.

On Nov. 6, southeast winds reached 20-25 mph and the water was 4 inches from the top of the bank. The tide went out in the afternoon, but it did not go all the way down. On Nov. 7, it was halfway between low tide and high tide and winds were calm. The water did not come to top of the bank and there was no flooding. The ice on the river was flowing, but had not really entirely formed 
from bank to bank. The ocean is completely clear of ice. Snow from October has all melted (Harold Okitkun, AIJ personal communication, November 7, 2018).

Storm impacts: No damage to infrastructure.

Key terms: Storm event - no flooding.

On Nov. 9, Kotlik experienced minor flooding and in some locations where water came over the bank. Flooding occurred around the AC Store and near the tide staff. Extremely low tides have been occurring. On Nov., high winds reached 42 to $43 \mathrm{mph}$ from the east and northeast. No damage was reported (Victor Tonuchuk, AIJ personal communication, November 13, 2018). Key terms: Minor flooding and high winds.

[Photos of flooding]

2019a, February 2019 storm \& weather narratives: Alaska Institute for Justice, 22 p.

Storm details: On the morning of Feb.11, strong southeast winds reached $37 \mathrm{mph}$ with gusts up to $45 \mathrm{mph}$ in Kotlik. In the afternoon, the wind switched directions coming from the south with winds gusting up to $60 \mathrm{mph}$. The wind direction and high wind speed remained the same throughout the afternoon and diminished in the late evening. On the evening of Feb. 11, strong southeast and south winds reached 40-60mph and the river ice was level with the top of the bank. Early morning of Feb. 12 , between midnight and 7AM the community of Kotlik was flooded. The elevated water was between 4-8 feet, but the snow in the village helped save it from being badly flooded. The tide went out in the afternoon of Feb. 12, but it did not go all the way down. As of Feb. 13, it is between low tide and high tide and winds are calm with temperatures at -17 . The ice on the river is frozen, but there are deep, widespread overflows (Victor Tonuchuk, AIJ personal communication, February 19, 2019).

Storm impacts: Flooding occurred, where 6 local homes were affected by the flooding in Kotlik. At least six homes were affected. Flood waters reached all of the homes to cause damage to foundations and insulation, and water seeped into the homes from the flood. Six items were damaged at the Kotlik tank farm: a 570 skidoo snowmachine, Honda 500 TRX Foreman, 12 volt battery charger, 2 Amp battery, Space Heater and Water Pump (Victor Tonuchuk, AIJ personal communication, February 19, 2019). Kotlik shared portions of this narrative with the State Emergency Operations Center (SEOC), but was told that the event was not big enough to qualify as a disaster (Victor Tonuchuk, AIJ personal communication, March 18, 2019).

[Photos of flooding]

2019b, March 2019 storm \& weather narratives: Alaska Institute for Justice, 9 p.

Event details: Kotlik experienced a high water event on March 26, 2019. High winds from the southeast started blowing on March 25, at speeds of $30 \mathrm{mph}$ with gusts up to $40 \mathrm{mph}$. Winds from southerly directions are favorable for flooding. The wind caused the Kotlik River to come up, starting on the morning of March 26. The river rose to the top of its banks. In the lower parts of town and on the north side of the island across from the main part of town, the water overflowed the banks. It did not flood homes or infrastructure in the village, but the water came up to the base of several homes that are located on the edge of the river bank. Between noon and 3:00 pm on March 26, the rising water slowed down, but continued to rise. The temperature was around 35 degrees (Victor Tonuchuk, AIJ personal communications, Mar. 26 \& April 1 \& 3, 2019; Harold Okitkun, AIJ personal communications, Mar. 26 \& 28, 2019). 
Event impacts: The Environmental Protection Agency has previously advised Kotlik that flood waters can present a health risk. Rising waters may come into contact with oil, human and animal waste, trash, and other contaminants. As the water recedes and pools, the contaminants settle with the water. Staff members of Bill Moore's Slough IGAP department posted warnings on Facebook asking Kotlik residents to warn children not to put their hands in their mouths or eyes after playing in the water because of the concern with health risks (Harold Okitkun, AIJ personal communications, Mar. 26 \& 28, 2019).

2019c, August 2019 storm \& weather narratives: Alaska Institute for Justice, 17 p.

Event details: Kotlik experienced winds of about 15 to $20 \mathrm{mph}$ from the east/southeast and higher gusts. When the wind switched to the south, the water really came in. There was heavy rain on Thursday and Friday. After heavy downpours on Thursday night, there was a lot of water on the ground. The tide went out, but did not go as low as it usually does. Between 6:00 am and 8:00 am, the tide came in really quickly and Kotlik experienced flooding. The highest water of the flood was around noon on Saturday, Aug. 3. The water rose over the boardwalks, to a height of about two and a half feet. (Harold Okitkun, AIJ personal communication, Aug. 5, 2019). A time lapse showing the flooding in Kotlik is available here: https://twitter.com/NWSFairbanks/status/1157760265468989441.

Event impacts: Kotlik received weather alerts and warnings from AIJ and DGGS and provided those warnings to the community by posting flyers around the community, making announcements on the VHF radio, and posting them on a community Facebook page. The warnings helped people to prepare and move property, such as snow machines, four wheelers, and fish nets, to higher ground or indoors. (Harold Okitkun, AIJ personal communication, Aug. 5, 2019). Flooding reached some homes and structures and water got into the floor insulation in homes in low lying areas. There was also damage to some boardwalks and some residents of Kotlik lost fishing gear and other personal items. (Victor Tonuchuk, AIJ personal communication, Aug. 20, 2019).

A representative of the Alaska State Emergency Operations Center called Kotlik's IGAP department after the storm, and the Kotlik IGAP department provided a storm report and photographs of the flooding to the State Emergency Operations Center. (Victor Tonuchuk, AIJ personal communication, Aug. 20, 2019).

The storm caused erosion along the coast from Pastolik River up to Point Romanoff. High banks eroded and chunks of mud and grass that eroded from the banks washed down to the beach. (Harold Okitkun, AIJ personal communication, Aug. 20, 2019).

[Photos of flooding]

2019d, September and October 2019 storm \& weather narratives: Alaska Institute for Justice, $14 \mathrm{p}$.

Storm Narrative for Kotlik, AK

Saturday and Sunday, October 5th and 6th, 2019

What is the duration (hours, days, and time of day) of the storm?

On October 3rd the wind began picking up and held throughout October 4th with gusts becoming stronger through the day. On October 5 th the wind was unpredictable as it would gust strongly for a few minutes and then die for a few minutes.

When did the [high] tide of the day/month occur? 
There was a high tide on the morning of October 4th - the Kotlik River was pretty rough with white cap waves forming and dying corresponding to the above unpredictable wind gusts. That evening there was a high tide at approximately 10:30PM which created a surge of water through the community - the first flooding event during the storm. There are photos of the tide scale which will be sent at a later date. On October 5th the tide went out normally in the morning, but in the evening around 10:30PM the water came up about a foot and a half in approximately one hour. In the early hours of October 6th water was coming in stronger and faster than on the 4th and 5 th and became deep fast. The water finally began going down around 4:30AM the morning of October 6th.

What was the wind direction?

Easterly and southerly (general direction).

What was the wind velocity/speed?

Throughout October 5th and 6th gusts kept regularly around 30-40mph (approximately).

Was there precipitation? If so, what kind?

There was rain. When it rained the wind gusts were the strongest at $45 \mathrm{mph}$ (approximately).

Did ice thickness/lack of sea ice impact the above storm events?

Sea ice was not mentioned, and perhaps not formed or was drifting close enough to shore.

Was there any damage to infrastructure or impacts on cultural subsistence activities?

People began preparing property on October 3rd and 4th by bringing things to higher ground and securing loose items outside. During the storm on the 5th and 6th there was a lot of scattered driftwood and scrap wood on and around the river bank.

Where did storm impacts occur within the community?

Standing water periodically stayed after high tide events around the community, and would go down sometime after the tide would go out. The river was rough and became deep the evening of the 5th and early morning of the 6th. Harold's boat was partially flooded at the stern in the river, but it was easily landed on the bank again with help from several others.

Another boat had entirely beached on the bank after a high tide, but it too was easily moved to land again on the bank. Several boats upriver were scattered off the landing, but there were no reports of flooded cabins, beached or damaged boats. Boardwalks through the community were displaced in some locations, but these were easily repaired and were operable for people to walk over. No homes or other types of personal property seem to be damaged, or no damage that Harold has heard of from community members.

Are there pictures to document any of the information collected above?

Harold stayed up through high tide events in the evenings and early mornings and documented water levels with photos. They will be sent at a later date.

Has the community reached out to any outside entities to assist with impacts?

Harold did not mention community leadership or other community members reaching out to outside entities, but he did mention it was very helpful to receive advance notice of the storm from Robin and Rick Thoman, and thereafter many community members passed the message along as often as they could so everyone to be most prepared. 
Are there specific resources that would be helpful?

No comment.

\section{City of Kotlik, 2013, Local hazard mitigation plan: City of Kotlik, 105 p.}

In the City of Kotlik, the highest risk to ice jams and snow melt flooding occurs in early summer, also referred to as breakup season. The highest risk to rainfall flooding occurs during late summer and early fall seasons. Most of the annual precipitation occurs April through October with August typically being the wettest month. The risk to rainfall generated floods corresponds to this cycle.

[Same information as URS (2007)]

[Lists DHS\&EM Disaster Cost Index for region]

City of Kotlik and Village of Kotlik, 2019, Multi-jurisdictional hazard mitigation plan: LeMay Engineering \& Consulting, Inc., 195 p.

Snowmelt run-off and rainfall flooding occur during spring thaw and the fall rainy season. Events occur from soil saturation. Several minor flood events cause damage. Severe damages occur from major floods. Kotlik experiences storm surge, coastal ice run-up, and coastal wind erosion along the shoreline and riverine erosion along the area's river, streams, and creek embankments from high water flow, riverine ice flows, wind, surface runoff, and boat traffic wakes. Kotlik sits on the Yukon River near the Bering Sea on the southern end of Norton Sound. Norton Sound is an arm of the Bering Sea. Storms in the Bering Sea have caused high water levels to back up along the Yukon River from the southern Norton Sound into the Kotlik community.

Short-fast ice is frozen ocean water that forms, grows, and melts in the ocean. Short-fast ice grows during the winter and melts in the summer, but some ice remains all year in certain regions. Kotlik sits on the Yukon River about five miles south of the Bering Sea on the southern end of Norton Sound. Norton Sound is an arm of the Bering Sea. Storms in the Bering Sea have caused high water levels to back up along the Yukon River from the southern Norton Sound into the Kotlik community. The community has experienced ice push (ivu). Ice push (ivu) is a surge of ice from an ocean onto the shore. Ivus are caused by currents, strong winds, or temperature differences pushing ice onto the shore, creating immense ice piles that can be shoved far inland and are capable of moving and destroying infrastructure and buildings.

In November 2013, the Village of Kotlik experienced a large flood in which salt water and ice from the Bering Sea made its way far into town. This flood potentially impacted traditional berry harvesting locations (USGS and Western Alaska Landscape Conservation Cooperative, 2018).

Furthermore, the advent of decreased sea ice and increased incidence of flood events have been observed in the Kotlik area.

Additionally, after the sea ice is present in the Bering Sea, and at the mouth of the Yukon River adjacent to Kotlik, and a fall/winter storm occurs, the storms break up the ice, and the ice is pushed inland into the community, jeopardizing foundations and infrastructure.

Many of the [flooding and erosion] problems are long-standing, although studies indicate that increased flooding and erosion are being caused in part by changing climate (DHS\&EM, 2018a). Flooding and erosion occur together in Kotlik because of increased water currents that get raised above the normal riverbank and slough. 
The following is a list of previous flood events in Kotlik:

1964 - Resident Victor Tonuchuk, Sr. recalled that the 1964 ice break flood reached six feet deep. Six public facilities, the powerhouse, the clinic, the teen center, and more than six homes were flooded (USACE, 1987).

1974 - In November 1974, two to four feet of water flooded Kotlik. The co-located City and Village limits were under water except for the cemetery. Approximately nine homes were flooded due to strong southwest winds (USACE, 1982).

1975 - Mayor Joseph P. Mike reported a flood and strong south winds in November which caused the fishing camps and five homes to flood. Flooding destroyed fish camps, which challenged access to nutritional foods (USACE, 1982).

1987 - This flood was the result of stream overflow and inundated Kotlik to a depth of two feet. Almost all houses were affected, in particular the Teen Center and several public buildings. The old and new runways were the only parts of town to not be affected by the flood (City, 2013).

October 7, 1989 - A 50-year flood occurred; 58 people were evacuated, and \$195,000 in damages occurred to 16 homes (City, 2013).

August 18, 1992 - The level of water was two feet above the average first floor of the affected homes; 108 people were evacuated, and 23 homes suffered damages, totaling nearly \$1.9 million.

November 13, 2011 - A low pressure system impacted the western coastline of the Y-K Delta. This event caused damages to Kotlik's Teen Center foundation $(\$ 39,927)$, City storage shed contents $(\$ 5,802)$, and one of Kotlik's shop $(\$ 177,421)$, which totaled $\$ 229,691$ in damages.

November 9, 2013 - A series of storms created a threat to life and property in the Lower Kuskokwim REAA. The storms resulted in damages to Kotlik's barge loading dock $(\$ 164,146.80)$, a destroyed honey pot basin $(\$ 5,068)$, the utilidor which acted as the community's water and sewage system $(\$ 5.5 \mathrm{M})$, the water and sewer system,

$(\$ 3,744,939)$ and dump burners, tents and fences $(\$ 404,306)$, and totaled $\$ 9,818,459$ in damages (A.Y. Gravier, personal communication, October 31, 2014). Without access to the utilidor, Kotlik was not able to properly dispose of their sewage or gain access to clean drinking water until the damage was fixed. 2017 - Kotlik experienced five flooding events (AIJ, 2019a).

From February 11-12, 2019, there was a storm and flooding event. A strong winter storm warning was in effect from February 11-12, 2019, for Kotlik and along the Yukon River Delta and coastal communities. Heavy snow and blowing snow occurred. Visibility was zero at that time. Strong southeast and south winds reached 40-60 mph. On the evening of the 11 th, strong southeast and south winds reached 40-60 mph, and the river ice was level with the top of the bank. By early morning of the $12 \mathrm{th}$, the community of Kotlik was flooded. The elevated water was between four to eight feet, but the snow in Kotlik helped save it from being badly flooded. The tide went out on the 12th, but it did not go all the way down. As of the 13th, it was between low and high tide, and winds were calm with a temperature of $-17^{\circ}$. The ice on the river was frozen, but there were deep, widespread overflows (AIJ, 2019b). Flooding occurred, where six homes were affected in Kotlik. Flood waters reached all six homes to cause damage to foundations and insulation, and water seeped into the homes. Kotlik shared portions of this narrative with the State Emergency Operations Center but was told that the event was not large enough to qualify as a disaster (AIJ, 2019b). 
Due to severe flooding, the Yukon River Towing Company raised several homes to reduce the impacts of flooding in residential homes in the early 2000s (AIJ, 2019a).

The majority of Kotlik's infrastructure is located along the Kotlik, Little Kotlik, Apoon Pass, and Yukon Rivers and is subject to flooding and erosion. Ten flooding events were documented between 1964 and 2019 with reported damages totaling $\$ 12,143,150$.

Table 6 identifies severe weather events from the NWS database for the Yukon River Delta which includes Kotlik. Not all events happened in Kotlik, but are included from a regional perspective.

[Table of severe weather events and descriptions in the region from 2001 to 2019]

[Same tsunami information as URS (2007)]

In 2013, community members observed a wind-driven bore tide on the river.

\section{D'oro, Rachel, 2013, W. Alaska residents clean up after coastal storm: Alaska Dispatch News [website]: found at https://www.adn.com}

The village of Kotlik was among the worst hit. The storm, pushing ice chunks to shore, damaged the water and sewer distribution system. An outdoor basketball court was moved 500 yards by rushing waters, school principal David Harris said Monday. His own house is 12 feet above ground on stilts, so it was not damaged, but if he had walked downstairs to the ground, he would have been chest high in water.

"The swiftness of the flooding, which I witnessed firsthand, was absolutely stunning," he said.

Because the sewage transfer equipment was down, the school was closed Monday, with plans to reopen it by Wednesday. But the school is offering shelter to village elders as well as people whose homes were damaged or moved. Because of the sewage problem, however, people are resorting to "honey buckets," 5-gallon pails lined with garbage bags.

Hovey, Davis, 2020, Minor to severe erosion across the region caused by strong Bering Sea storm: KNOM [website] found at: https://www.knom.org/

In Kotlik, Victor Tonuchuk Jr. the local IGAP coordinator said there wasn't much damage from the storm locally, no erosion that he noticed, and some minor flooding due to high wind. But, Tonuchuk noted that there is no sea ice in the Yukon River near Kotlik currently either.

\section{Indigenous Environmental Network, 2013, Heavy storm devastates coastal communities in western Alaska: Indigenous Environmental Network [website]: found at https://www.ienearth.org}

[This is a collection of news sources recounting the November 2013 storm]

A heavy storm overnight (Nov. 10) flooded the coasts of Western Alaska and wreaked havoc in several communities.

In Kotlik, located on the Yukon River Delta, the storm flooded the (village of) Kotlik slough, causing severe damage when ice chunks were shoved up the banks.

State officials say Kotlik has reported damage to its sewage and water facilities and to five homes. Jacqueline Gosch, a Kotlik resident, says the ice also pushed dry-docked boats onto higher land, and the village's boardwalk was completely washed away and redistributed in other parts of town. 
Some brief footage I took of the flood on November 10, 2013. Ice shoved up over the river bank, boats washed up on shore that crushed utility lines, pools of frozen flood water, the school's basketball court drifted 100 yards away, more damaged utility lines, etc.

https://www.youtube.com/watch?v=Q14DP8s-4Ag

[Copy of article by Megan Edge - Alaska Dispatch]

Sudden flooding and severe ice jams in the village of Kotlik — a coastal Yukon River Delta town of about 630 people south of Norton Sound — damaged sewage systems, closed the community's school, displaced families and cut off the community's access to any running water over the weekend.

"The town was actually a part of the ocean," Kotlik Mayor Thomas Sinka [Jr.] said Monday. "I mean everything was underwater, and our rescue teams were trying to get to all of these people, but the flooding happened so fast we just couldn't."

He added that sea ice was pushed into the town and surrounding rivers, making it more challenging to perform search and rescue operations.

Sinka said the water from Pastol Bay came rushing into the Yup'ik village on Saturday. He said more than 100 people, families and their pets headed to the local school for shelter.

Damage at the fueling station caused diesel to spill into the village, he said. Sewage pipes floated away and the sewage water was in the streets. The playground equipment at the school was taken away with the current, and the school had no heat or running water. People have lost their homes. And multiple people posted on the Kotlik Facebook page claiming that much of the Alaska Native subsistence food that was hunted and gathered over the summer has been destroyed.

Alaska Department of Homeland Security spokesman Jeremy Zidek confirmed that the community's water system had been knocked out and the water plant damaged.

"They have about 2 weeks of water within their water tanks," Zidek said. "It can't be distributed (by the system), but they can haul it." He added that Kotlik would have to resort to using honeybuckets for their sewage needs, at least for the time being.

[Copy of article by Zaz Hollander and Devin Kelly - ADN]

A rushing surge of seawater and ice destroyed the village's sewer and water distribution lines and damaged at least five homes, state emergency officials said.

Water and floes of ice began rushing into William Odinzoff's Kotlik home Saturday night. It happened so quickly that the flooding stranded him and six other members of his family. By the time a rescue boat arrived hours later, about 10 inches of water had pooled inside, Odinzoff said.

Odinzoff and his family spent the next two nights at Kotlik School, which served as the village evacuation center. More than 200 people stayed at the school Sunday night, said Principal David Harris.

The floodwaters shifted the school's outdoor concrete basketball court 500 yards — it now sits intact behind the village post office.

Recovery efforts focused on clearing large ice chunks from the village's main boardwalk, which is also the main transportation corridor to the local airstrip. Initial damage estimates were between $\$ 500,000$ to a million dollars, said the village mayor, Thomas Sinka.

Kotlik's piped vacuum sewer and circulating water utility corridor — known in village Alaska as the utilidor — were both badly damaged by the storm. The flood surge pushed back the utilidor, break- 
ing it in half up against the boardwalk, and also tore water and sewer lines from individual homes, said Jimmy Okitkun, pastor at the Kotlik Assembly of God church.

Odinzoff, who came to Kotlik in 1969, said the damage is the worst he's ever seen. Mud now cakes the floor of his house, where his family returned Monday to try to clean up the debris. He also lost a freezer full of food.

Unseasonably warm fall temperatures have left the coast without the armor of solid sea ice that protects it from storms, a scenario that also occurred in with the "epic" November 2011 storm that hammered comunities [sic] from Point Lay to Newtok, Zidek said.

It was 37 degrees in Unalakleet just a few days ago, Dickens said.

"The ocean never froze up," he said. "if it's frozen or slushy, that helps a lot."

\section{Kotlik CEDS Committee, 2004, Kotlik comprehensive economic development strategic plan (CEDS): Kotlik CEDS Committee, 22 p.}

The terrain is a marshy lowland of alluvial deposits and the rivers are surrounded with willows. The community is prone to floods during autumn as tides are extreme with the fall storms. Concurrently, spring ice break-up normally does not cause floods as there are many other drainages along the delta fan and Kotlik is located near the edge of the fan and is last to become affected by the river outflow. The Andreasky Hills are located about 25 to 30 miles to the east of Kotlik. The Bering Sea or the southern Norton Sound is about 6 miles north of the community.

The Kotlik Yupik Corporation and the City Utilities have a new consolidated tank farm with construction completed 2002. There are 9 48,000 gallon storage tanks built on piling and it is elevated well above the floodline.

\section{Kotlik Tribal Council, 2006, Kotlik community development plan: Kotlik Tribal Council, 99 p.}

An intense fall flood during the early 50s drew floating chunks of ice and damaged a trading post and some homes at Chaneliak. The damage created enough concern that the Bureau of Indian Affairs built a new school about 5 miles up the Yukon River in a community now known as Kotlik.

[Same as Kotlik CEDS Committee (2004)]

Power Generation \& Distribution

A new City Generation Plant with 4 new generators (2 each @ 275kw and 2 @ 420kw) and electronics to sense electrical need was completed in 2002. The plant was constructed on steel pilings elevated above the flood line. The plant has an underground fuel supply line from the new bulk fuel storage tank facility.

The Yukon Delta (where Kotlik is built) was formed over hundreds of years of silt being deposited allowing growth of the delta fan. This alluvial deposit remains permanently frozen underground and causes periodic upheaval. Shifting of the land has posed foundation problems for many buildings. Locals are aware that even lands previously above the flood plain now are covered with water. The older HUD homes within the community had foundations replaced where the pads were placed upon the frozen permafrost, insulated and covered with existing soil. Shifting and sinking continued. The newer HUD homes have steel pilings forced into the ground to 38 feet. They seem to be holding steady so far. But, we fear this elevated boardwalk will shift and weave requiring additional funds to repair. 
As the community grows, there is more mail and freight being hauled from the airport to the post office, stores, homes and the school. Distribution of freight alone requires heavier ATVs and larger freight carts. The old boardwalk, built in 1980 was constructed of 2\&rdquo;x 6\&rdquo; [sic] boards and is in serious need of repair. We are threatened with the fact that if freight is undeliverable from the airport airlines will quit delivering food and other items necessary for existence in the village.

Kotlik Tribal Council, 2010, Kotlik community development plan: Kotlik Tribal Council, 43 p.

[same as Kotlik Tribal Council (2006)]

\section{NOAA Storm Data Reports:}

November 1974:

On November 11, 1974, a [disastrous] storm struck the northwest coastal region of Alaska. Communities from Deering in the north to Hooper Bay in the south, suffered heavy damages. Recovery efforts were immediately initiated with immediate needs taken care of by various State and Federal Agencies. The area was declared a disaster area under Public Law, 93-888 by President Ford.

Kotlik: Water damage to several houses. Moderate structural damage to two houses. One boat, two motors, two snowmachines, and two barrels of gasoline lost. Estimate approximately 42 claims for unmet losses.

October 1987:

An intense Bering Sea storm brought winds to $75 \mathrm{mph}$ and minor flooding to the Yukon-Kuskokwim delta coast. Four seal hunters were drowned when their boat went down off of Sheldon Point. Some beached boats were damaged at Tooksook Bay and Emmonak.

October 2002:

[Describes storm impacts in Kivalina, Kotzebue, and Shishmaref on October ${ }^{\text {th }}$.]

November 2003:

[November $8^{\text {th }}$ describes storm impacts to several west coast communities.]

Kotlik: Boardwalk was damaged.

[November $22^{\text {nd }}$ describes storm impacts to several west coast communities.]

Kotlik: The bank erosion project completed in October was further damaged by the storm.

October 2004:

[October $19^{\text {th }}$ has detailed description of storm and impacts in several communities]

Alakanuk, Kotlik, surge heights unknown.

Kotlik: Ocean water rose two to three feet and floated Boardwalks off their supports. Water and waves damaged the school's skirting and eroded the gravel around the foundation. This in turn exposed insulation covering permafrost ground and water pipes and insulation to the school building itself.

October 2006:

[Flooding occurred in the region]

May 2009: 
The combination of a significant amount of water and ice flowing down the Yukon river along with ice jams near Kotlik and shore-fast ice at the mouth of the Yukon River produced minor flood in Kotlik during the afternoon hours of the 25th through the early morning hours of the 26th. Water came over some roads on the north side of the village near the new airport, but the roads were still passable and no homes were flooded. No information available on property damage, a preliminary estimate is guessed at $\$ 0$.

November 2011:

Water levels rose an estimated 5 feet above the normal mean low water levels at Kotlik on the morning of the 9th and crested at approximately 1130AKST. The water levels then fell rapidly after 1330AKST and within a couple of hours were back to normal.

November 2013:

An intense and large storm in the Bering Sea produced a long fetch of strong wind across the Bering Sea aligned with the Kuskokwim Delta coast November 6th through the 9th. This produced a surge of up to 5 feet along the Kuskokwim Delta Coast.

January 2013:

Coastal flooding in Kotlik

January 2017:

Back to back strong low pressure systems affected much of the state over several days from December 28th 2016 until January 2nd 2017. Freezing rain in the Bristol Bay area, strong wind, heavy snow and blizzard conditions for the west coast and interior as well as minor coastal flooding with higher than normal storm surges ( 5 to 9 feet) occurred along the southern Seward Peninsula over the course of several days.

Strong southerly winds of 50 to $65 \mathrm{mph}$ pushed sea ice on shore and water levels rose in several villages. Villages along Norton sound reported high surge values of 5 to 9 feet breaking up the ice near shore and pushing it up onto the land. High water on roads and near homes were reported in Nome Savoonga and [Unalakleet]. High winds damaged buildings in Kotzebue along with power outages.

Gambell runway on Saint Lawrence Island received flooding and minor damage to lighting. Airport was closed. Savoonga received power outages and over 30 homes had roofing damage. Golovin old runway was inundated with water and half a foot from reaching lowest area of the village. Boats reported missing at Shishmaref.

Zones 211 and 212: Minor coastal flooding in Norton sound due to the water level rise and sea ice pushed into villages. Nome minor flooding of homes along Belmont Point.

Zone 213: Coastal flooding of Gambell airport.

Zone 214: Coastal flooding in Kotlik

Zone 207: Minor coastal flooding near Shishmaref. Boats reported lost. 


\section{U.S. Army Corps of Engineers, 1982, Flood history survey-Kotlik: USACE Alaska District, 6 p.}

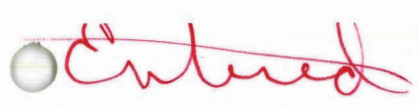

VIHAGE:_ Ketik Alaske 42420 Page 1 of 3

present village Chief (or Mayor): Joseeh pmike

Village status (home rule, 2nd class, traditional, IRA, etc):

$$
\text { Lucoed clas }
$$

Worst Flood known (cause and date):

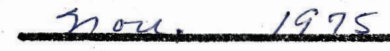

Depth of Flood (MAXIMUM):

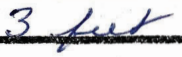

Uighwater Marks (Describe \& Locate):
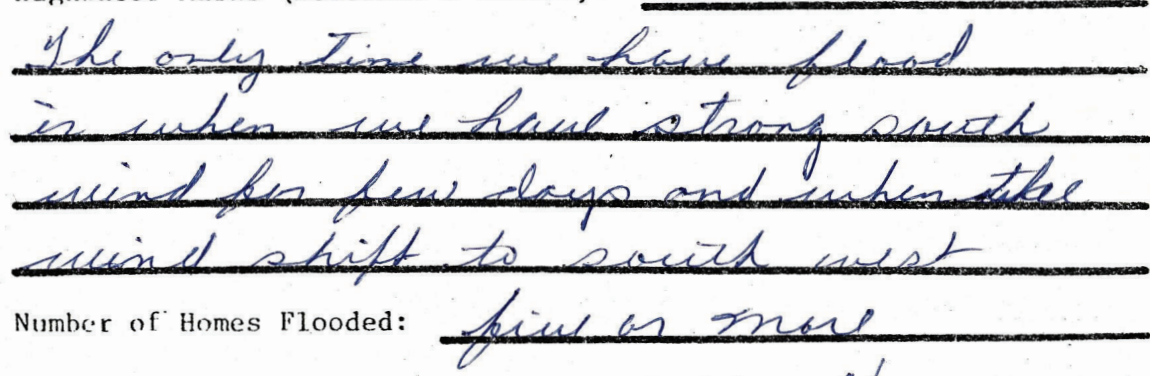

Number of Public Facilities and Type Flooded:

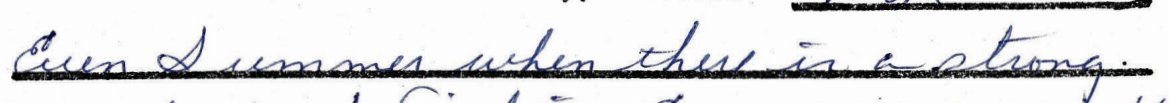

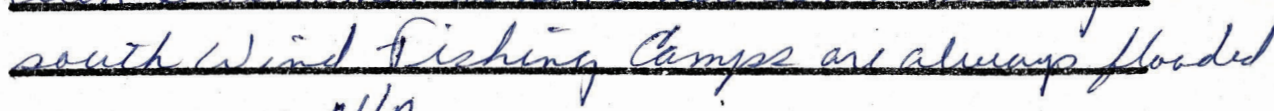

Total Damage in $N / A$

Most frequent cause of flooding (ice jams, stream overflow, wind driven

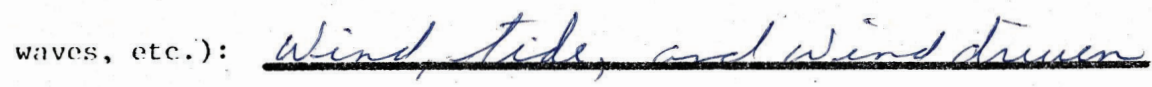

Nases

other Years Flonded: $D / A$.

Publication:

0

Number of Homes: 
vII.ACE: Lielech

Village Informat ion (con't)

Accoss (air, boat, etc.):

Bronomic Activity (substance hunting \& fishing, mining, commercial fishing, native arts \& crafts, supply point, etc.):

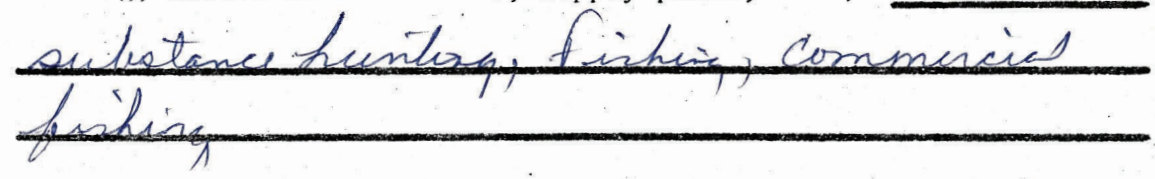

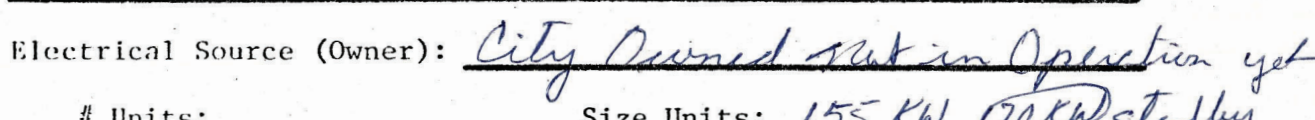
\# Units: Size Units: $155 \mathrm{KW} 20 \mathrm{KW}$ stardluy

Fuel (gas, diesel, nat. gas): aliesul

Type (int. comb., turbin, etc):

Water Supply:

How obtained: 100000 etwage Tesk

Is It Treated? :

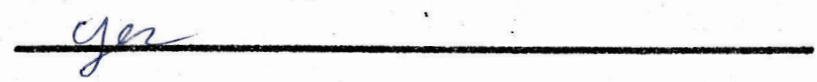

Sewer System (cesspools, privies, PHS, etc.)

In Use?:

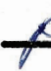

P1anned:

communications (Owner): (soited Utilitien

Bushphone: Radio: other:

village corp (if any): Lotlik Vupit Corperation President: Latty dhikhalc 
VHIACR:

Kotiik

Page 3 of 3

Other Pertinent Information (erosion \& other problems):

Lle isty hos sosion problem and it is $\frac{\text { eroding fist }}{\text { Roselis need sting tial dichind }}$

RETURN TO:

PREPARED BY:

Mlaska District Engineer

Corps of Engineers

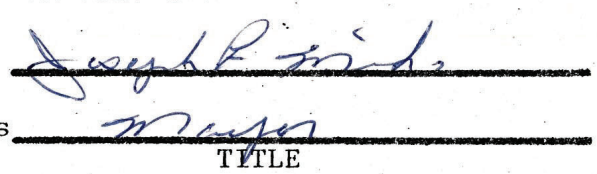

P. O. Box 7002

Anchorage, Alaska 99510 


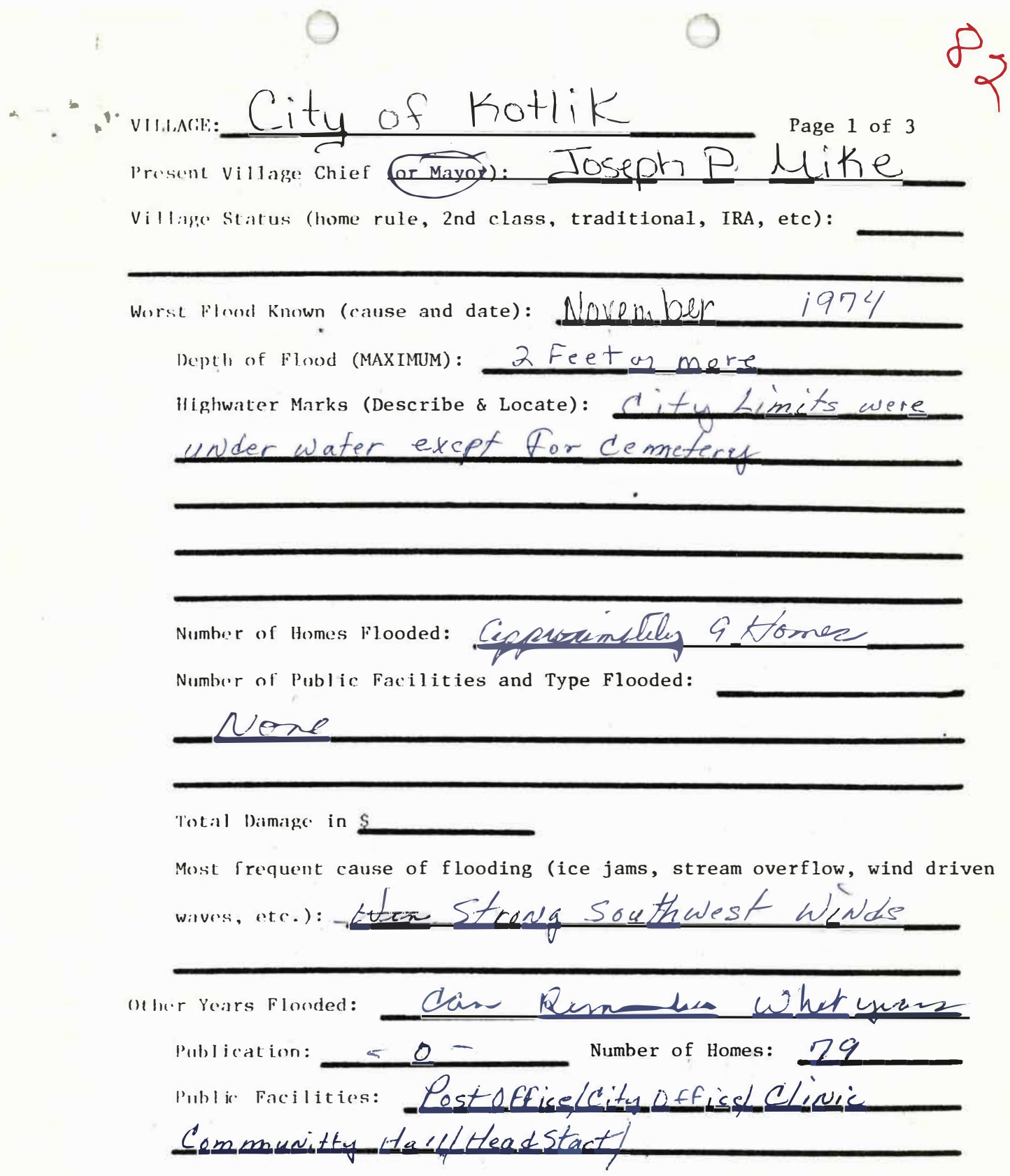


vilincis: BOTLIK

Villasice Informaltion (con't)

Acersis (air, boat, etc.): Air, Boat Snow Machine

liconomic Activity (substance hunting \& fishing, mining, commercial lishing, native arts \& crafts, supply point, etc.):

Subsistince tuarting \$/Fishing dommencial Fishing Irapeina

linctrical source (owner): Kotlik Electije Sevuices

\# Units:

Size Units:

Fuel (gas, diese1, nat. gas):

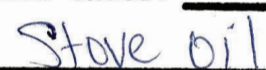

'rype (int. comb., turbin, etc):

Witcr Supply:

How obtinined: from the school

Is it Treated?: Jes, with ool

Siwor System (cesspools, privies, PHS, etc.)

In Use?:

Planned: Washiteria \& Sauna willbe built summer of 82 communications (Owner): ClNited Utilities Anchorage AK. City Office $\frac{899-4313}{K}$ Radio: $\frac{N / A}{N}$ other: NIA village Corp (if any):

President: Aloyisas ulasuli 


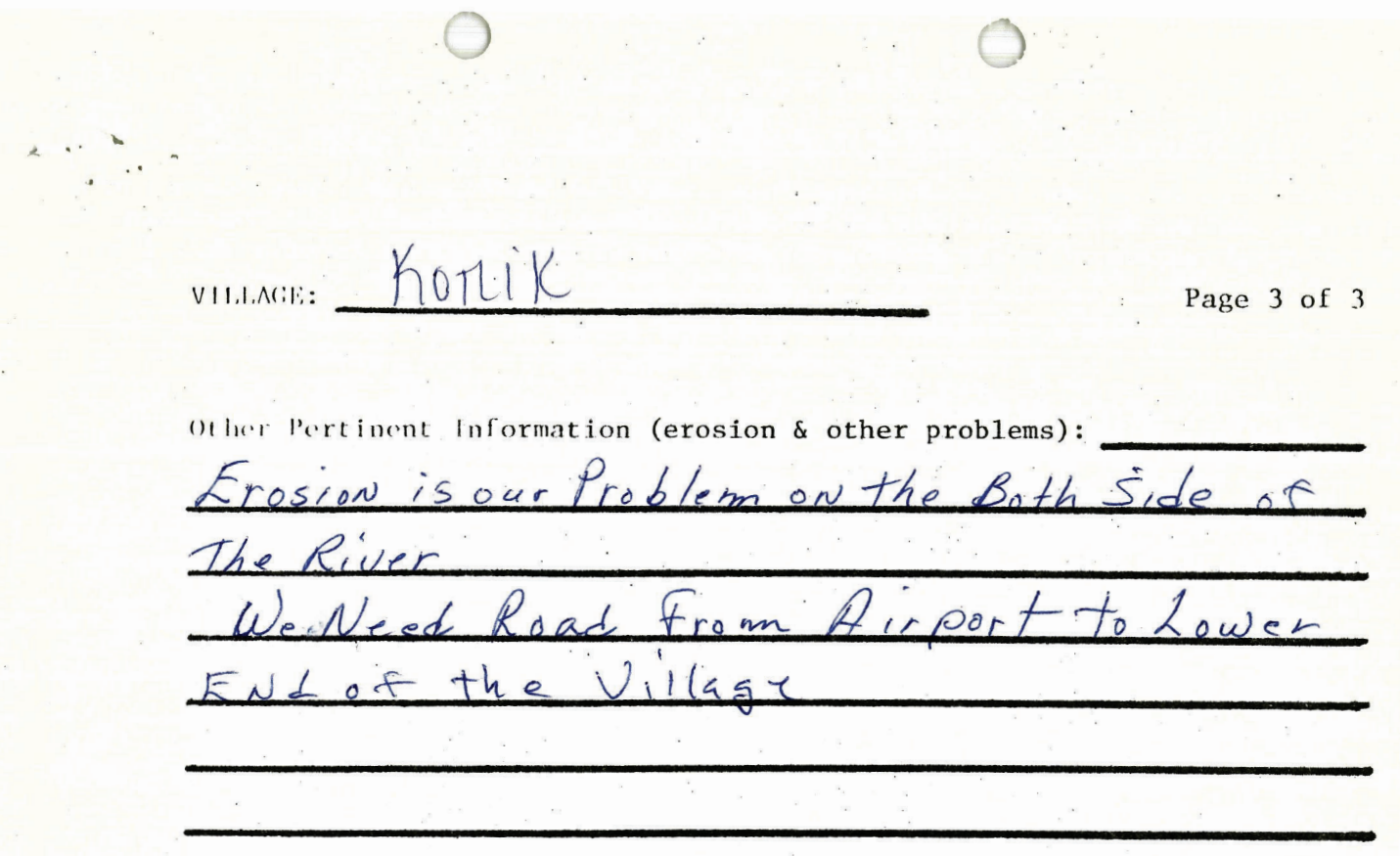

RI:TURN TO:

$$
\begin{aligned}
& \text { Linilu Okitkus } \\
& \text { Cinp: or lingincers }
\end{aligned}
$$$$
\text { P. } 0 . B 0 \times 7002
$$$$
\text { Amelonraye, Alaska } 99510
$$ 


\section{7, Flood history survey-Kotlik: USACE Alaska District, 3 p.}

$-\ldots$

vILLAC: KOH,K

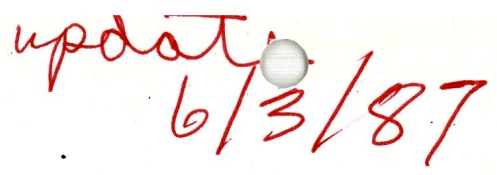

present village Chief (or Mayor): Victor Tonuchut Sr.

Village status (home rule, 2nd class, traditional, IRA, etc):
2nd Class City. (Also, their is a tribal Gov. here)

Worst Flnnd Known (cause and date): 1964 (icebreak)

Depth of Flood (MAXIMUM):

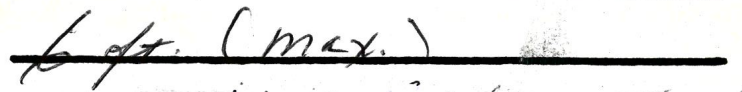

Highwater Marks (Describe \& Locate-doRst Kuin Foud

Hewched the Sita shop-(powerhouse) nidd

Part of town abo bovered the

whole part of town, and ienched

the tundtrithozik is pocated in the

Number of Homes Flooded: low / und lineas are

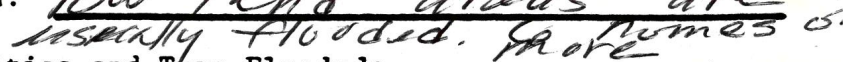

Number of Public Facilities and Type Flooded:

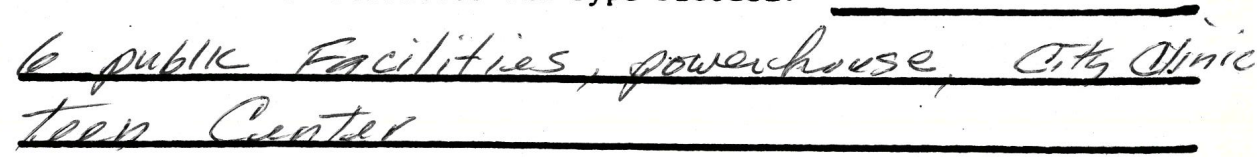

Tnta] Damage in $S \subset U$

Most frequent cause of flooding (ice jams, stream overflow, wind driven waves, etc.): 1 ce jams, fall Time (wind
druven waves)

other years Flonded: 1965 Pall time

Publication: Number of Homes: 97 homes lpresk

Public Facilities: City Clune, City office Gity hall City Shop, Teen Couter and Cit.

\section{Once 1}


V]I,I.ACiE:

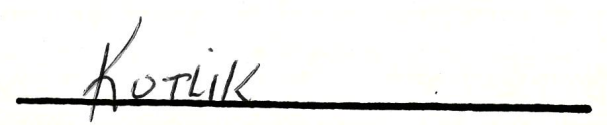

Page 2 of 3

Village Information (con't)

Access (air, boat, etc.):

Ficonomic Activity (substance hunting \& fishing, mining, commercial

rishing, native arts \& crafts, supply point, etc.):

Substance

hunting t fishina, Cimm ercial Acshine pative Artso Crafts, Wullace Corperation, citg quournments

Blectrical Source (Owner): Owher

\#Units: 4 umit Size Units: $2-150 \mathrm{KW} 1-25 \mathrm{KW}$

Fuel (gas, diesel, nat. gas): diesel

Type (int. comb., turbin, etc): lpterna (Ponb.

Water Supply:

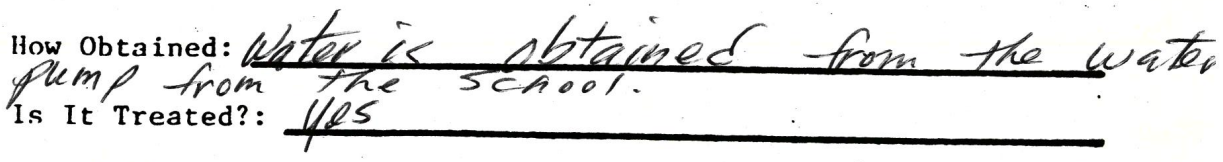

scwer System (cesspools, privies, PHS, etc.) NO Seweer System

In Use?: -

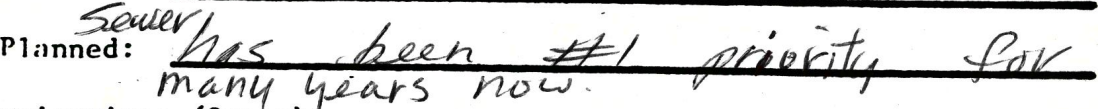
Communications (Owner)!

Bushphone:

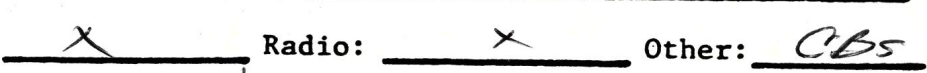

village Corp (if any):

President: Robert OKitKun 
virins: KoTtLik

Page 3 of 3

other Pertinent Information (erosion \& other problems): erOS/D problem, un Campleted sil erosion still the priority ciso the

RETURN TO:

U.S. Army Engineer District, Alaska ATTN: NPAEN-PL-FP (C) P.0. Box 898

Anchorage, Alaska 99506-0898

PREPARED BY:

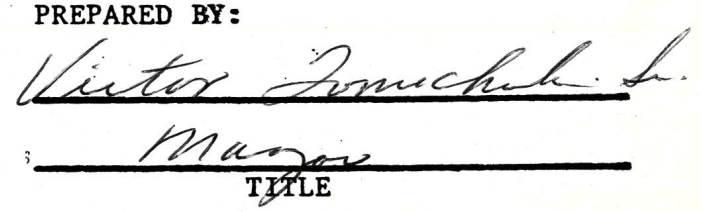




\section{8, Erosion information paper-Kotlik, Alaska: USACE Alaska District, 5 p.}

Description of Erosion Problem

Natural fluctuations in flows and water levels, flooding, ice jams, spring break up, and wave action from boat wakes and wind reportedly cause and contribute to bank erosion along the Kotlik River waterfront. The soil structure is weakened with the semi-annual thaw-freeze cycle and is eroded of ice abrasion, waves, and occasional high tides from Norton Sound. There has been an annual loss of about 3 feet per year of riverbank over the past 10 years with recent major erosion events in 2002, 2003 and 2005.

2011, Alaska floodplain management flood hazard data-Kotlik: USACE Civil Works Branch, 1 p.

Last flood event: 1987

Flood of record: 1974

Floodplain Notes: the following elevations were based upon an arbitrary elevation of $100.00 \mathrm{ft}$ given to the doorsill of the school.

SURVEY INFORMATION JUNE 19951974 flood level 96.69 Recommended building elevation 98.67 Front door of the new school (facing river) 100.00 Bottom of the water tank for the school 97.69 Center of the sill of the large door on the power plant 97.63 First floor of the Post Office 97.45 Doorsill of the armory 97.03 Centerline of the airstrip at the end nearest town 96.53 Large city water tank 95.85 Rim of the wall around the washeteria fuel tanks 94.89 Front step of the Post Office 94.72 Small city water tank 94.39 Approximate bottom of the school fuel tank farm 93.69 Typical bottom of the washeteria fuel tanks 92.56 Low corner of the wall around the city fuel tank farm 92.41 Teen Center 91.88 Typical bottom of the fuel tank farm 89.98

Flooding was about $4 \mathrm{ft}$ deep during the 1974 flood. A waterline mark was left on the city hall 24" above ground level and on the water storage tank 23 " above ground level. Water in the community was about $2 \mathrm{ft}$ deep during the 1987 flood.

[The following photos are incorrectly labeled as a 1963 ice jam]

1963 Ice Jam, Photo 1 [monochromatic aerial single frame of Kotlik dated July 30, 1963]

1963 Ice Jam, Photo 2 [monochromatic aerial single frame of Kotlik dated July 22, 1975]

1963 Ice Jam, Photo 3 [monochromatic aerial single frame of Kotlik dated May 31, 1984]

1963 Ice Jam, Photo 4 [monochromatic aerial single frames of Kotlik dated May 31, 1984]

\section{2, Kotlik flood plain survey: Flood history survey-Kotlik: USACE, 13 p.}

\section{Purpose of Visit and General Information}

On June 18, 2012, Nathan Epps and Graham Foreman travelled to Kotlik, AK to survey building elevations and convert the flood of record elevation to the NAVD88 datum. Flood elevations were previously established by the Alaska District in 1994 using an arbitrary elevation as a benchmark. Kotlik is located on the south bank near the mouth of the Kotlik River which discharges into the Apoon Pass of the Yukon River Delta. 


\section{Flood History}

The flood of record occurred in 1974 during a fall storm. The 1974 flood was marked on a fuel storage tank and surveyed to an arbitrary datum in 1995 by the Alaska District; however that tank has since been removed. The elevation of the 1974 flood was determined based on the survey notes from the 1995 Corps survey. The team met with city councilwoman Lorrena Price during the site visit to gather more information on flooding events in Kotlik. Recent flooding in Kotlik was caused by an ice jam forming downstream of Kotlik and creating a backwater that inundates the area. Due to local topography, flooding is noticed on the Kotlik River to the south of the community before the Yukon River runs out of bank when this type of event occurs. The 2011 breakup caused minor flooding with water reaching the foundation posts of the City Office and submerging some of the older boardwalks in the western part of the community. Notes from a 1983 Alaska District trip to Kotlik indicate ice on Apoon Pass is typically 1.5 to 2 feet thick with 3 feet not being unusual.

\section{Vertical Datum}

The local datum used to survey high water marks in Kotlik by the Alaska District was the front door of the school facing the river. This point was assigned an arbitrary elevation of 100.00 feet. A review of the National Geodetic Survey datasheets for vertical benchmark near Kotlik revealed that the closest recorded benchmark is 2A9 A (PID DM4108) which is located at the east end of the Kotlik runway, approximately 1 miles to the southwest of town. The monument is the primary airport control station for the Kotlik airport. The NGS datasheet reports 2A9 A to have an elevation of 10.63 feet NAVD88. The monument was found at $63^{\circ} 02^{\prime} 10.2^{\prime \prime} \mathrm{N}, 163^{\circ} 31^{\prime} 36.1^{\prime \prime W}$. Two secondary airport control stations were available, but not tied into the survey due to time constraints. A temporary vertical control point was established on a foundation bolt of the community boardwalk to minimize the effect of traffic vibrations.

\section{Survey}

Survey was performed with a Leica Sprinter 250M. Weather at the time of the survey was sunny, $70^{\circ} \mathrm{F}$ and calm, dropping to $50^{\circ} \mathrm{F}$ towards the end of the survey. The area surrounding Kotlik is very marshy; low lying ground was typically inundated with a foot or more of water and higher ground was covered in springy moss. The community uses boardwalks instead of gravel roads. Tripod and rod locations were chosen carefully to be over boardwalk foundation beams to minimize deflections caused by the weight of the survey crew and passing traffic. Boardwalk foundations were on piles driven into the ground, however the driving depth is not known and some foundations were noticeably springy. Three loops were surveyed to tie the old school floor elevation into the NAVD88 monument at the airport. The distance from the school to the airport monument was approximately 5600 feet and was surveyed in 34 shots with intermediate shots to tie in floor elevations between the two points. The cumulative error over the three loops was 0.338 feet. Closure errors were averaged over each loop. The loop closure errors ranged from 0.004 to 0.02 feet of error per shot. The errors were likely caused by response of the boardwalks to passing traffic. It is recommended that future surveys of boardwalk communities be performed with GPS survey equipment. While the vertical accuracy of the level is superior to GPS measurements, due to ground instability, cumulative errors over long loops with a level can exceed the accuracy of GPS equipment. GPS equipment is assumed to have a vertical accuracy around 0.2 feet.

[Photos of surveyed buildings] 
Table 1. Flood elevation and building floor elevations.

\begin{tabular}{c|c} 
Location & NAVD88 Elevation (feet) \\
1974 Flood & 14.12 \\
\hline Old School & 17.43 \\
\hline City Office & 15.14 \\
\hline National Guard Armory & 15.80 \\
\hline Native Store & 14.48 \\
\hline Tribal Lodge & 11.93 \\
\hline Tribal Office & 14.64 \\
\hline Alaska Commercial Company Store & 15.48 \\
\hline Kotlik School & 13.91 \\
\hline
\end{tabular}

\section{U.S. Army Corps of Engineers, 2021, Ice jam database: USACE [website]: found at https://icejam.sec.usace.army.mil/}

\section{2-MAY-28}

Ice Jam Flood Watch Bulletin, 1530 hrs, Friday, May 28, 1982, "An ice jam flood watch is issued for Emmonak...Alakanuk...Kotlik...and other locations on the Yukon River Delta Friday. The watch will be in effect through Sunday. Breakup has moved into the Delta today...moving ice was reported just 10 miles upstream of Emmonak. The ice at Emmonak is forecast to start breaking up late Friday afternoon....and at Alakanuk by Sunday. River levels are expected to reach bankfull with possible flooding of low lying areas. Residents in the Delta region should take precautions to protect property this weekend until the ice goes out."

0930 hrs, May 29, "An ice jam has formed a few miles upstream of Emmonak...causing water levels to drop four feet downstream at Emmonak and Alakanuk. along with cold and cloudy weather... breakup in the delta may take a couple of days."

1315 hrs, May 30, "An ice jam flood watch [remains] in effect Sunday for Emmonak... Alakanuk... Kotlik...and other locations on the Yukon River Delta. An ice jam a few miles upstream of Emmonak on the Yukon River formed last Friday and is still holding solid. The jam may break at any time... but could also remain solid for the [next] couple of days. water us spreading over the banks upstream of the jam. Residents on the Yukon River Delta should continue to watch for a sudden rise on the river...or for overland flow of water around the jam ...until the jam breaks some flooding is likely."

1530 hrs May 31, "The ice jam that formed Friday evening a few miles upstream of Emmonak is still holding and water levels have changed little over the past 24 hours. The jam is solid and huge pressure ridges up to 40 feet have formed. It may break at any time...but could also remain solid for the next couple of days. Water is spreading over the banks upstream of the jam. There are no flood [problems] on the Yukon River today...but a flood watch has been issued for Emmonak...Alakanuk...Kotlik...and other locations on the Yukon River Delta. These communities should be alert for [rapidly] rising water levels and possible flooding. There is also a possibility of overland flow around the jam." 


\section{5-JUN-03}

[Flood watch issued 6/3]

\section{6-MAY-31}

NWS River Ice Breakup Summary 6/1/86 1500 hrs, "Breakup is in progress in the delta of the Yukon River. A minor ice jam above Emmonak broke Sunday and ice was flowing by Emmonak very swiftly. The water level was 4 to 6 feet below flood stage. The ice broke [up] at Kotlik a couple of days ago. The middle channel still had original ice on it Sunday morning but it [is] expected to go out at any time. There have been no flooding problems reported during this years breakup in the delta."

\section{7-MAY-26}

River Ice Breakup Summary, 1500 hrs, Tues. May 26, 1987, "An ice jam flood watch will go into effect at noon Wednesday for Emmonak, Alakanuk and Kotlik on the Yukon River Delta. High flows were passing Russian Mission Tuesday and will be arriving in the Delta around midday Wednesday. The ice in the Delta appears to be strong and ice jams may form and cause flooding. The river is ice free above Holy Cross."

\section{9-MAY-27}

1000 hrs Wednesday May 31, 1989, "The ice jam flood warning in effect for Emmonak and Alakanuk has been cancelled. The Yukon River is now ice free on the southern channel out to the Bering Sea ice. Flooding is over at Emmonak and Alakanuk...and the villages are drying out this morning. Water levels at Sheldons Point remain high today...but no threat of flooding exists. The northern channels remain partly ice covered...but no flooding threat is [foreseen] at [Kotlik]."

\section{4-MAY-20}

NWS Flood Statement 10 am May 20, 1994, "Water levels did not change overnight in Emmonak and Alakanuk with no flooding [occurring] in either village. A pilot report from 9:30 Friday morning states that the main Yukon channel remains blocked about 10 miles upriver from Emmonak. A secondary ice jam is reported Friday morning upstream form Emmonak in Kwiguk pass the outlet channel of the Yukon River passing Emmonak. A third jam blocks the main Yukon channel near Alakanuk. With the drop upriver and no change at Emmonak or Alakanuk it is now assumed that the middle mouth of the river has opened up and is relieving the considerable backup of overbank water upstream from Emmonak. At last aerial observation of this channel on Wednesday it was jammed near where it separated from the main channel about 20 miles upriver from Emmonak. Kotlik a village on the north mouth reports a rise of 2 to 3 feet since Thursday further evidence that water has broken through the ice blocking the channel that both the north mouth and middle mouth share."

URS, 2007, Hazard mitigation plan-City of Kotlik, Alaska: URS, 116 p.

The following is a list of previous flood events in Kotlik:

1974 - This record rainfall flood is the most severe the community ever experienced. The entire village was inundated to a depth of 4 feet.

1987 - This flood was the result of stream overflow and inundated the village to a depth of 2 feet. Almost all houses were affected, in particular the Teen Center and several public buildings. The old and new runways were the only parts of town to not be affected by the flood.

October 7, 1989 - 50-year flood, 58 people were evacuated and \$195,000 in damages occurred to 16 homes. 
August 18, 1992 - The level of water was 2 feet above the average first floor of the affected homes, 108 people were evacuated, and 23 homes suffered damages totaling nearly $\$ 1.9$ million.

A historic flood insurance rate map (FIRM) exists from 1977 for the Kotlik area; however, there is not a current FIRM.

The entire community of Kotlik is vulnerable to the effects of flooding.

Recorded historical flooding information indicates that Kotlik experiences flooding every 2 to 13 years, and it is expected these intervals of flood events will continue. Therefore the probability of a flooding event impacting Kotlik is highly likely. Critical impacts to the community from flooding events could occur including injuries and/or illnesses resulting in permanent disability, complete shutdown of critical facilities for at least 2 weeks, and more than 25 percent of property could be severely damaged. Specific impacts resulting from floods include water damage to boardwalks, infrastructure, buildings (both critical and noncritical facilities) and structural damage caused by floating debris such as ice.

The entire community of Kotlik including all critical facilities is vulnerable to flood impacts.

A series of storms struck the west coast of Alaska causing major coastal flooding November 11 through 13, 1974. Significant damage occurred in the communities of Deering, Shishmaref, Nome, Wales, Brevig Mission, Teller, Golovin, Elim, Koyuk, Shaktoolik, Unalakleet, St. Michael, Stebbins, Kotlik, Alakanuk, Scammon Bay, Sheldon Point, Hooper Bay and Kotzebue. Unalakleet was the hardest hit due to a combination of flooding and wind damage. Portions of the Nome community were submerged in 10 feet of sea water.

Tsunami events have not been officially documented in Kotlik; however, during the hazard screening process, a community elder reported that tsunami events have previously occurred on two occasions. The first account is of a tsunami Impacting Kotlik on November 10, 1952. The day was very calm and then someone noticed water coming onto land. Suddenly the sea ice burst, water rolled into the slough and raced through the City. Gasoline tanks drifted away with various other belongings. All homes in the community were flooded about knee high. The entire population (approximately 200) stayed in the Catholic Church for a couple of nights until water drained from the homes.

The second account of a tsunami event occurred in January 2005. Water remained in low-lying areas for more than 6 hours.

Wise, J.L., Comiskey, A.L., and Becker, R., Jr., 1981, Storm surge climatology and forecasting in Alaska: Anchorage, Alaska, Arctic Environmental Information and Data Center, University of Alaska, 32 p.

[November 10, 1974 storm]

REGIONS: Kotzebue Sound, Norton Sound, Lower Yukon, Kuskokwim Bay

COMMUNITIES: Deering, Shishmaref, Wales, Brevig Mission, Teller, Nome, Golovin, Elim, Koyuk, Shaktoolik, Unalakleet, St. Michael, Stebbins, Kotlik, Alakanuk, Scammon Bay, Sheldon Pt., Hooper Bay, Kotzebue

INCLUSIVE DATES: 10/11/1974 TO 12/11/1974

DAMAGE: Unalakleet $\$ 250,000$; Tin City $\$ 90-100,000$; Shaktoolik $\$ 20,000$; Teller $\$ 100,000$; Sheldon Point $\$ 20,000$; Hooper Bay $\$ 35,000$; Nome $\$ 18,000$. Flooding occurred on 11, 12, and 13 of Nov. Some parts of Nome under $10 \mathrm{ft}$ of water. 
MAXIMUM SURGE: $25 \mathrm{ft}-4 \mathrm{ft}=21 \mathrm{ft}$

COMMENTS: This storm was actually a series of three storms from November 10-12, as a quasistationary storm over the Chukotsk $[$ sic $]$ Peninsula and two frontal waves. This allowed a long fetch in the south Bering.

[August 18, 1978 storm]

REGIONS: Lower Yukon, Kuskokwim Bay

COMMUNITIES: Kotlik, Emmonak

INCLUSIVE DATES: 19/8/1978 TO 21/8/1978

DAMAGE: \$50,000 damage to boats, motors, fishing equipment and fuel lost to residents of Kotlik and Emmonak.

MAXIMUM SURGE: $6 \mathrm{ft}$ approx.

COMMENTS: A storm moved from 55N 176W NNE at $26 \mathrm{kts}$ for 24 hours to near Nome on the morning of August 20. Flooding occurred on the western exposures of the Yukon Delta. 


\section{APPENDIX B: FLOOD CATEGORY CALCULATION FIGURES}

DGGS staff visited Kotlik in July 2021 and surveyed points relevant to the flood history and category study. The Trimble R10 base station was installed over a benchmark with a published solution (found at https://www.ngs.noaa.gov/OPUS/getDatasheet.jsp?PID=BBGX51). Points were surveyed with the Trimble R8s receiver. Horizontal coordinates are provided in WGS84 latitude and longitude and NAD83 (2011) UTM Zone 3N easting and northing. Elevations are provided in orthometric height (meters above NAVD88 [GEOID12B]) and converted to feet above local MHHW using the tidal datum by NOAA CO-OPS (2021). MHHW is $6.28 \mathrm{ft}(1.913 \mathrm{~m})$ above NAVD88.

Table B1. First floor heights of buildings used in report, as measured by CRW Engineering Group, LLC, in 2021.

\begin{tabular}{ccc} 
Building & Height (ft NAVD88) & Height (ft MHHW) \\
School & 15.7 & 9.4 \\
\hline Fuel tank farm & 15.6 & 9.3 \\
\hline Water treatment plant & 14.6 & 8.3 \\
\hline Water tank & 15.2 & 8.9
\end{tabular}

Table B2. Coordinates and heights of surveyed features. Latitude and longitude are in decimal degrees WGS84. Northing and easting are in meters NAD83 (2011) UTM Zone 3N. Orthometric heights are in meters above NAVD88 (GEOID12B).

\begin{tabular}{|c|c|c|c|c|c|c|c|}
\hline Feature & Figure & Latitude & Longitude & Northing & Easting & $\begin{array}{l}\text { Ortho. } \\
\text { Height } \\
\text { (m) }\end{array}$ & $\begin{array}{l}\text { Height } \\
\text { above } \\
\text { MHHW (ft) }\end{array}$ \\
\hline Riverbank & B5 A & 63.03373596 & -163.54679218 & 6990179.125 & 573520.279 & 2.568 & 2.15 \\
\hline Riverbank & B5 B & 63.03379997 & -163.54649977 & 6990186.590 & 573534.909 & 2.689 & 2.55 \\
\hline Riverbank & B5 C & 63.03414088 & -163.54391657 & 6990227.524 & 573664.718 & 2.446 & 1.75 \\
\hline Riverbank & B5 D & 63.03455827 & -163.54187317 & 6990276.363 & 573767.026 & 2.607 & 2.28 \\
\hline Riverbank & B5 E & 63.03478744 & -163.54033584 & 6990303.657 & 573844.209 & 2.659 & 2.45 \\
\hline Old clinic & 1 & 63.03335738 & -163.55366657 & 6990129.109 & 573173.490 & 3.655 & 5.72 \\
\hline House from $70 \mathrm{~s}$ & 1 & 63.03368116 & -163.54773689 & 6990171.940 & 573472.629 & 3.661 & 5.73 \\
\hline $\begin{array}{l}\text { Ground at } 1975 \\
\text { residence }\end{array}$ & 2 & 63.03374612 & -163.54647264 & 6990180.622 & 573536.417 & 2.866 & 3.13 \\
\hline Teen center ground & 4 & 63.03114223 & -163.56190977 & 6989872.991 & 572762.026 & 2.856 & 3.09 \\
\hline Teen center first floor & 4 & 63.03112609 & -163.56192533 & 6989871.175 & 572761.279 & 3.994 & 6.83 \\
\hline School skirting & 5 & 63.03156802 & -163.55445773 & 6989928.879 & 573137.952 & 3.666 & 5.75 \\
\hline $\begin{array}{c}\text { Boardwalk by flood } \\
\text { staff }\end{array}$ & 6 & 63.03418270 & -163.54104870 & 6990235.472 & 573809.680 & 3.188 & 4.18 \\
\hline Porch step & 8 & 63.03444709 & -163.54068574 & 6990265.341 & 573827.371 & 3.500 & 5.21 \\
\hline Building ground & 9 & 63.03710504 & -163.52861299 & 6990575.349 & 574431.270 & 3.050 & 3.73 \\
\hline AC ramp bottom & 10 & 63.03369558 & -163.54414874 & 6990177.653 & 573654.098 & 2.766 & 2.80 \\
\hline $\begin{array}{c}\text { March } 2019 \text { flooded } \\
\text { step }\end{array}$ & 11 & 63.03694653 & -163.52943067 & 6990556.746 & 574390.317 & 2.818 & 2.97 \\
\hline Ground near camera & 12 & 63.03402972 & -163.54454000 & 6990214.427 & 573633.463 & 2.784 & 2.86 \\
\hline
\end{tabular}




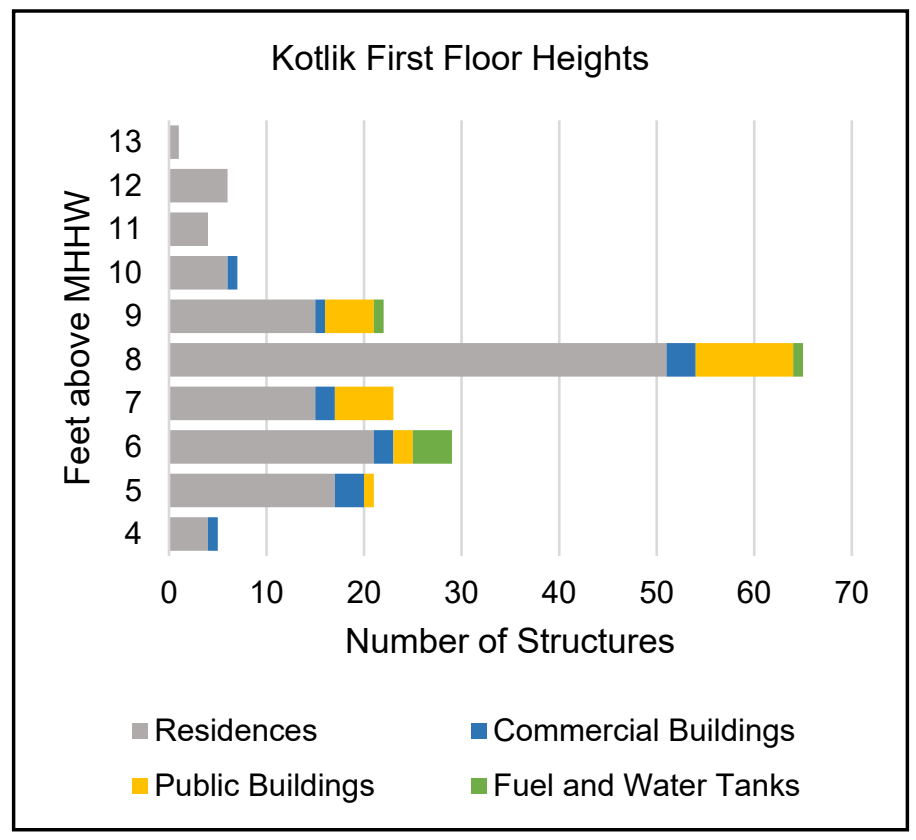

Figure B1. Histogram of building first-floor elevations in Kotlik. Most structures are at or above $8 \mathrm{ft} \mathrm{MHHW.}$
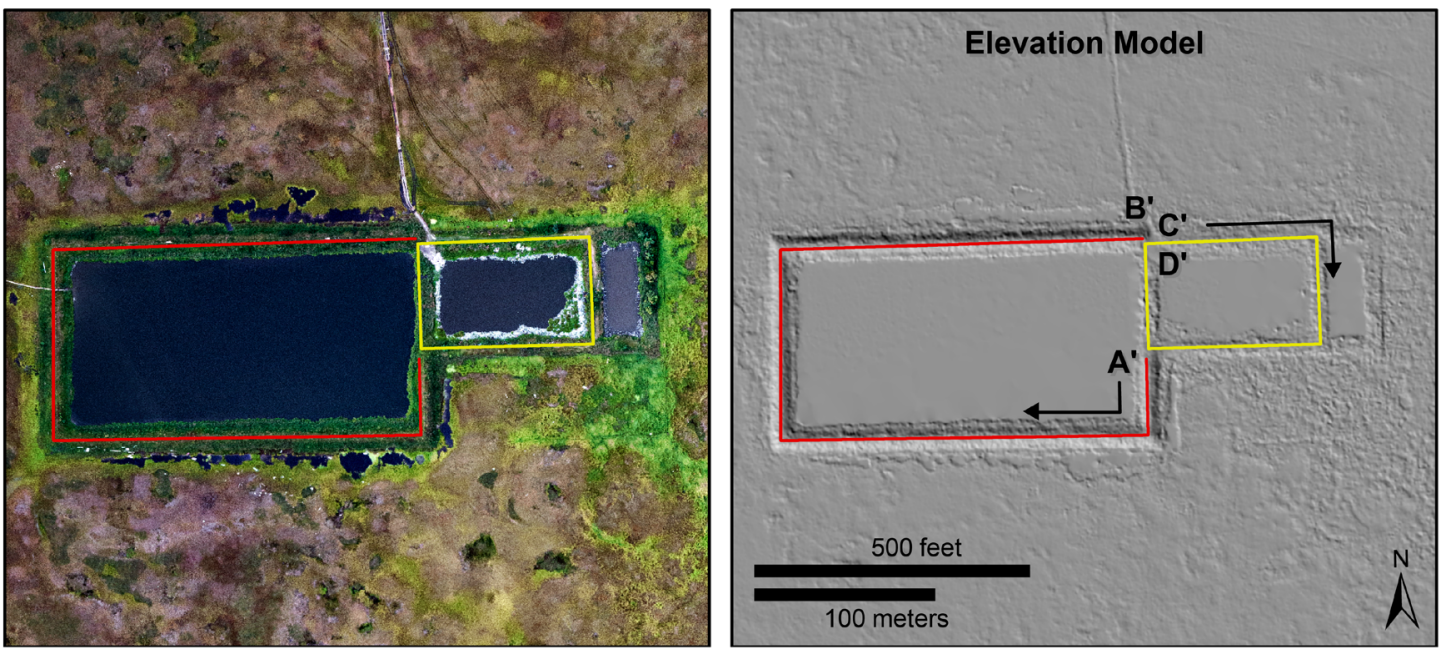

Wastewater Lagoons

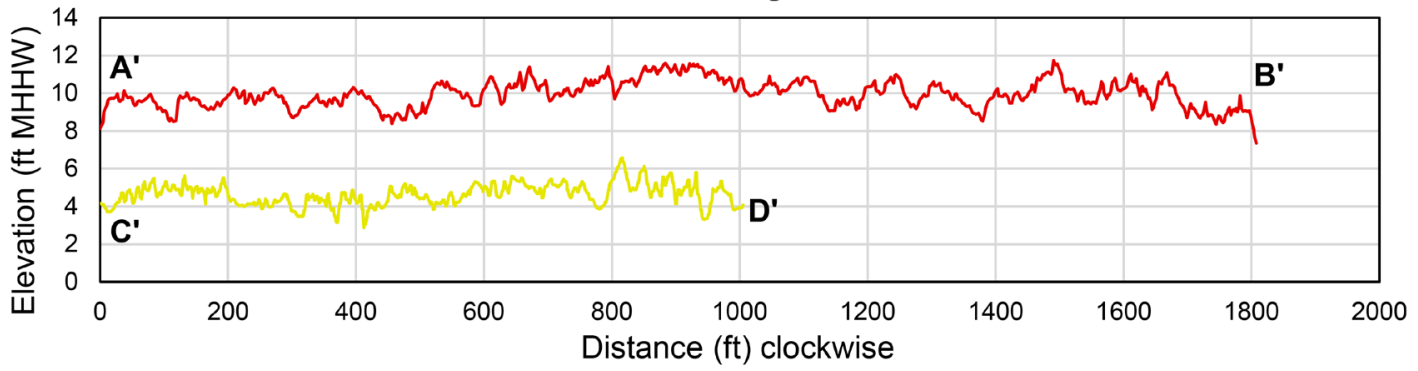

Figure B2. Kotlik's west wastewater lagoon (red) receives wastewater from the water treatment plant via pipe. The east lagoon (yellow) receives untreated hauled waste. Both have berms and cyclone fence reaching approximately 5 feet above the berm. Elevation profiles drawn on DTM show the west lagoon berm ranges between 8 and $12 \mathrm{ft} \mathrm{MHHW}$. The east lagoon berm ranges between 3 and $6 \mathrm{ft} \mathrm{MHHW}$. 

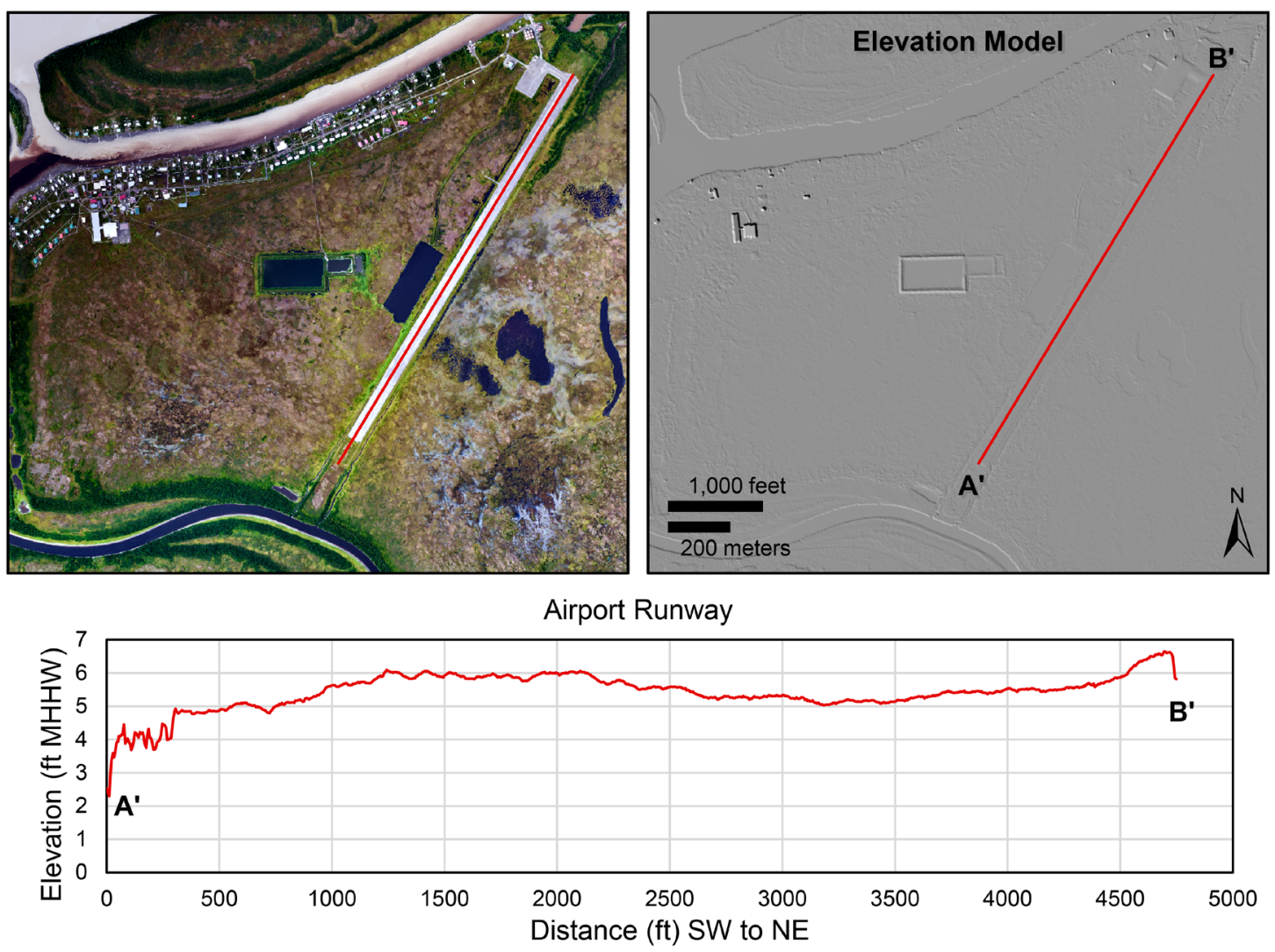

Figure B3. Elevation profile drawn on DTM shows the airport runway ranges between 5 and $7 \mathrm{ft} \mathrm{MHHW.}$
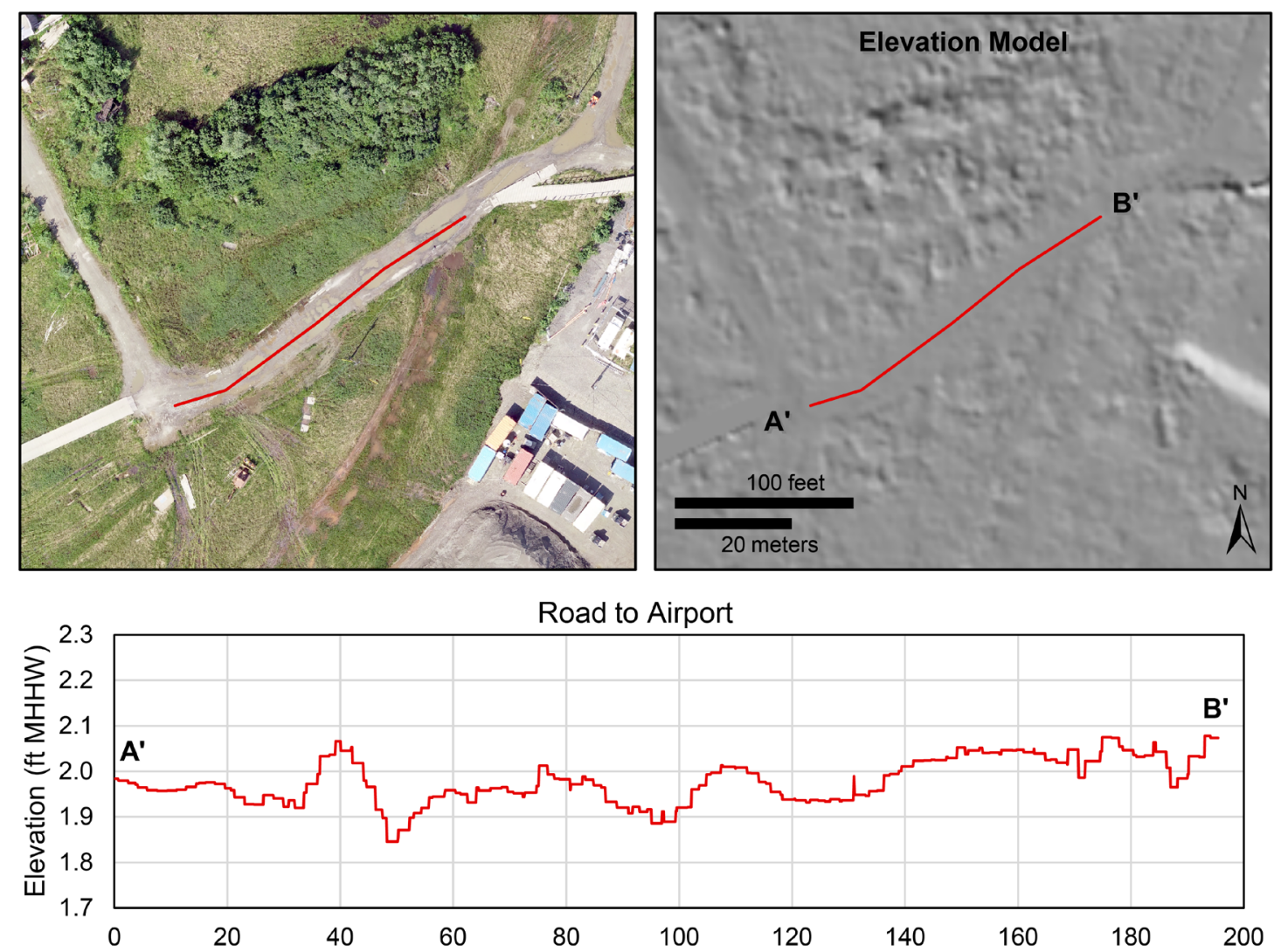

Figure B4. (Top) Image and elevation model (DTM hillshade) of the lowest section of road between the boardwalk system and the airport in Kotlik. The elevation profile (red line) drawn on the image is graphed below. The average height is $2.0 \mathrm{ft} \mathrm{MHHW} \mathrm{(standard} \mathrm{deviation}=0.05 \mathrm{ft}$ ). 

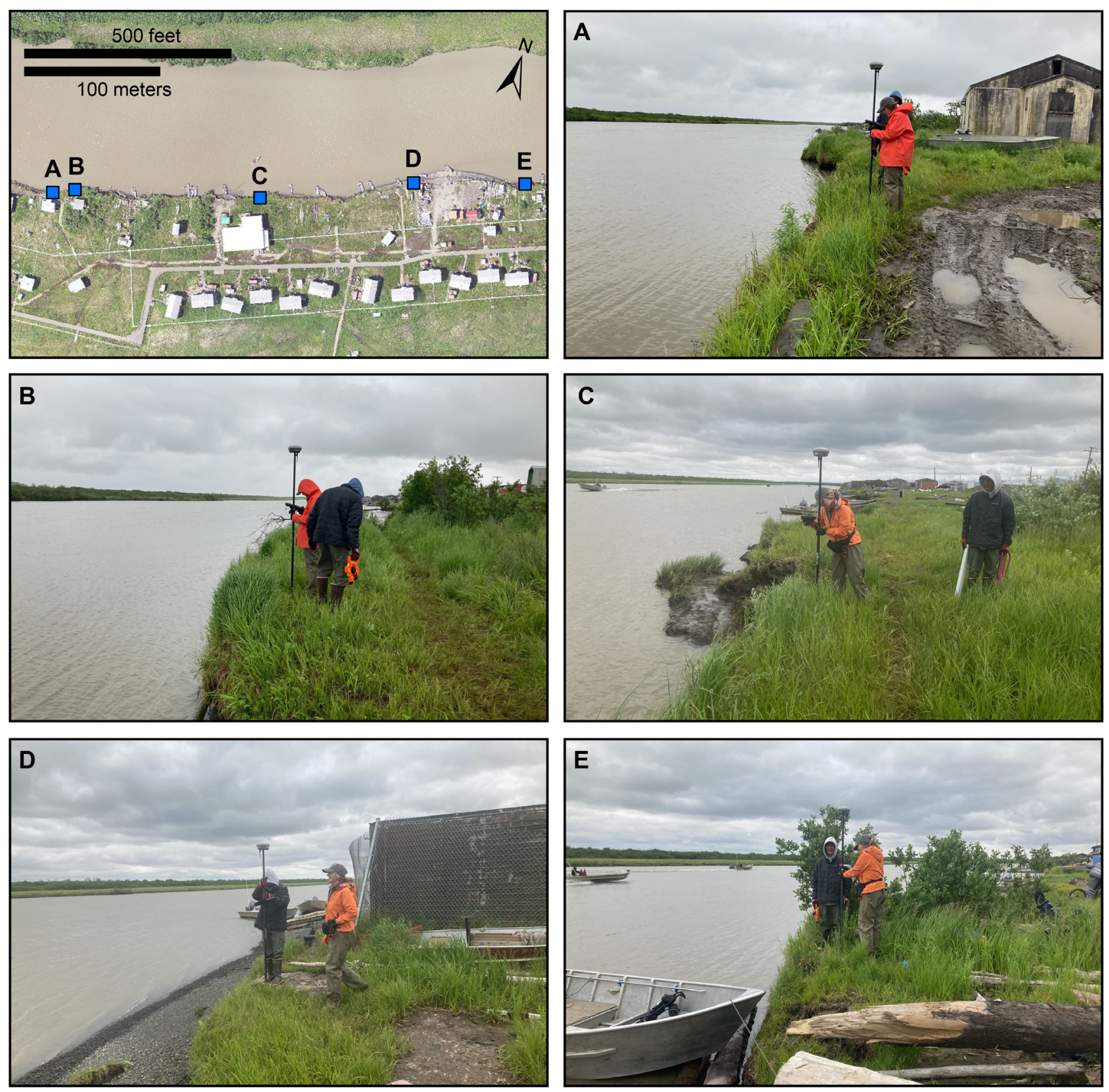

Figure B5. GNSS measurements used to estimate riverbank height are taken around the Alaska Commercial store. The first panel shows a map of measurement locations with labels corresponding to the following panel photos. 